University of Louisville

ThinkIR: The University of Louisville's Institutional Repository

Electronic Theses and Dissertations

$12-2013$

\title{
Southern honor, Confederate warfare : southern antebellum cultural values in Confederate military operations, 1861-1865.
}

Matthew D. Goldberg

University of Louisville

Follow this and additional works at: https://ir.library.louisville.edu/etd

\section{Recommended Citation}

Goldberg, Matthew D., "Southern honor, Confederate warfare : southern antebellum cultural values in Confederate military operations, 1861-1865." (2013). Electronic Theses and Dissertations. Paper 511. https://doi.org/10.18297/etd/511

This Master's Thesis is brought to you for free and open access by ThinkIR: The University of Louisville's Institutional Repository. It has been accepted for inclusion in Electronic Theses and Dissertations by an authorized administrator of ThinkIR: The University of Louisville's Institutional Repository. This title appears here courtesy of the author, who has retained all other copyrights. For more information, please contact thinkir@louisville.edu. 


\title{
SOUTHERN HONOR, CONFEDERATE WARFARE:
}

\section{SOUTHERN ANTEBELLUM CULTURAL VALUES IN CONFEDERATE MILITARY OPERATIONS, 1861-1865}

\author{
By \\ Matthew D. Goldberg \\ B.A., University of Louisville, 2011

\begin{abstract}
A Thesis
Submitted to the Faculty of the

College of Arts and Sciences of the University of Louisville

In Partial Fulfillment of the Requirements

For the Degree of
\end{abstract}

Master of Arts of History

Department of History

University of Louisville

Louisville, Kentucky

December 2013 
Copyright 2013 by Matthew D. Goldberg

All rights reserved 

SOUTHERN HONOR, CONFEDERATE WARFARE:

\author{
SOUTHERN ANTEBELLUM CULTURAL VALUES IN CONFEDERATE \\ MILITARY OPERATIONS, 1861-1865 \\ By \\ Matthew D. Goldberg \\ B.A., University of Louisville, 2011 \\ A Thesis Approved on
}

November 15, 2013

by the following Thesis Committee:

Dr. Glenn Crothers

Dr. Daniel Vivian

Dr. Julie Peteet 


\section{DEDICATION}

This thesis is dedicated to my parents, Steven and Tyler Goldberg, who have encouraged my love of history since I was a child; my fiancé, Alex Fox, for her loving support; and for two mentors, Bryan Rich, who encouraged me to become a historian, and for Glenn Crothers, who taught me how. 


\section{ACKNOWLEDGEMENTS}

I would like to thank my thesis advisor, Dr. Glenn Crothers, for his guidance, patience, and belief in me. I would like to thank Dr. Daniel Vivian and Dr. Julie Peteet

for their assistance during the writing of this thesis. I would also like to thank my fiancé, Alex Fox, for her incredible patience, understanding, and loving help during this process. Also, thanks to my parents, Steven and Tyler Goldberg, for their longstanding support of my academic endeavors. 


\section{ABSTRACT \\ SOUTHERN HONOR, CONFEDERATE WARFARE: \\ SOUTHERN ANTEBELLUM CULTURAL VALUES IN CONFEDERATE MILITARY OPERATIONS, 1861-1865

\author{
Matthew D. Goldberg
}

November 15, 2013

This thesis examines the role antebellum southern cultural paradigms played in Confederate military operations during the American Civil War. The prewar honor culture of the white southern male elite was intensely focused on chivalric values of courage, masculinity, piety, pride, contempt for cowardice, and loyalty. When war broke out between the United States and Confederacy, the southern elite moved from their prewar position as economic, political, and social leaders to military commanders. The violent and militaristic culture that characterized the prewar southern elite guided their actions as the military leadership of the Confederacy. Using the written record of the Confederate elite, campaign overviews, secondary literature about the period, and statistical studies of the Confederate army, this thesis finds strong evidence of the impact of the antebellum culture on the Confederate officer corps. 
TABLE OF CONTENTS

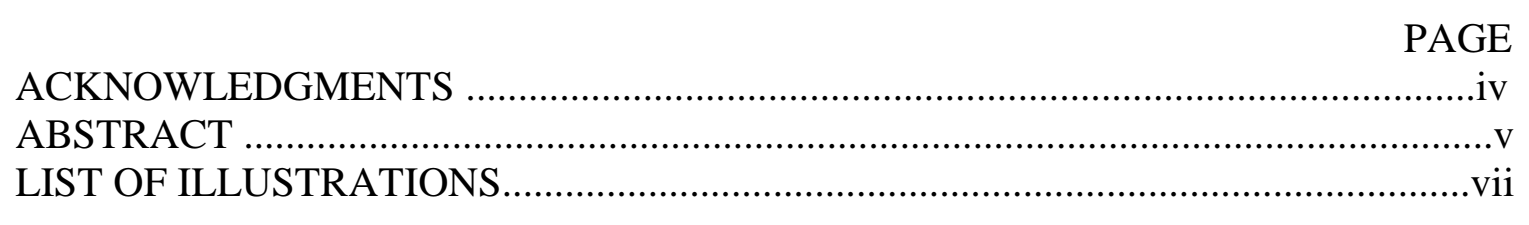

INTRODUCTION: SOUTHERNERS, SOLDIERS, AND SLAVERY ...........................

CHAPTER 1: MOONLIGHT, MAGNOLIAS, AND MILITARISM............................11

CHAPTER 2: COURAGE, CONFIDENCE, AND CAVALIERISM ...........................44

CHAPTER 3: DEFIANCE, DECLINE, AND DOWNFALL.......................................98

EPILOGUE: RECONSTRUCTION, RADICALS, AND RECIDIVISM.....................149

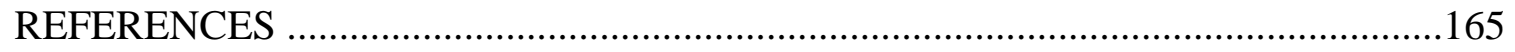

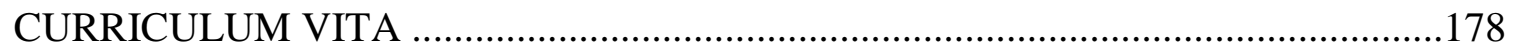




\section{LIST OF TABLES AND ILLUSTRATIONS}

TABLE/ILLUSTRATION PAGE

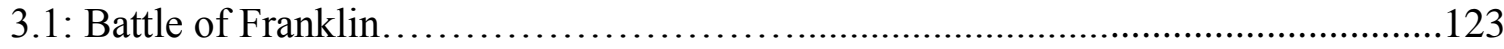

3.2: Generals killed/mortally wounded by year............................................................131

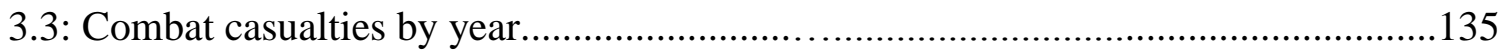

3.4: Soldiers captured in selected engagements..............................................136

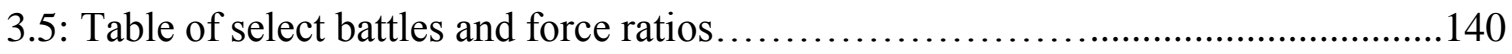




\section{INTRODUCTION: SOUTHERNERS, SOLDIERS, AND SLAVERY}

This thesis examines the role of antebellum southern culture and its place in Confederate military operations during the American Civil War (1861-1865). Using paradigms of white southern elite behavior first identified by authors such as Bertram Wyatt-Brown, Kenneth S. Greenberg, John Hope Franklin, and W. J. Cash, the thesis demonstrates the ways that violence, militarism, elitism, and masculinity affected the strategies, operations, and tactics of Confederate commanders. It evaluates the concept of southern cultural uniqueness and the ways that combat reflected cultural paradigms specific to the region. By concentrating on the antebellum values of elite southerners during the Civil War, the thesis reveals how important peacetime cultural principles shaped the wartime setting. In short, this thesis determines how cultural patterns of the antebellum southern elite affected their approach to warfare. Examining this question fully requires determining how Confederate military practices differed from prevailing military dictums of the time. To this end, the thesis examines the military context of Napoleonic Europe to demonstrate how Confederate operations both reflected contemporary military tactics and departed from them. This style of historical inquiry uses traditional military history techniques to assess battlefield operations, but concentrates on newer methods of cultural history. In addition, the thesis undertakes a statistical appraisal of Confederate battlefield performance. By examining the written record of the officers and through data-driven research, it answers the central question of how antebellum cultural patterns affected Confederate operations. 
Assessing how southern cultural values shaped the Confederate military requires three distinct sets of historical documents: primary literature from the officer class, secondary literature from southern cultural historians, and statistical data from the battles and campaigns of the war. The writings of Confederate commanders reveal their motivations and beliefs during the war. The secondary literature of the period offers crucial insight into the primary record. Secondary literature like Bertram Wyatt-Brown's Southern Honor: Ethics and Behavior in the Old South, W. J. Cash's The Mind of the South, Kenneth S. Greenberg's Honor and Slavery: Lies, Duels, Noses, Mash, Dressing as a Woman, Gifts, Strangers, Humanitarianism, Death, Slave Rebellions, the ProSlavery Arguments, Baseball, Hunting, and Gambling in the Old South, and John Hope Franklin's The Militant South, 1800-1861 lays the framework for understanding the unique regional character of the antebellum South that defined how southerners approached their daily lives. ${ }^{1}$

Elite white males, who belonged to the planter class of the southern slavocracy also dominated the officer class of the Confederacy during the war. Determining what they believed before the war is central to understanding how they conducted the southern war effort. Wyatt-Brown, Greenberg, and Franklin have argued convincingly that southern society was characterized by a deeply formulaic and militaristic honor code that governed the daily lives of whites. This honor code was a major part of the slave society that guided white male behavior and informed its adherents how to reinforce their status within the social caste. Central to this highly public form of social display was the slave system itself. Race-based slavery in the southern states was a brutal, violent, and endemic factor in the lives of every southerner. Violence between master and slave, both physical 
and psychological, served as a major form of social control over the large black subject population. But despite the commonplace nature of violence between master and slave, white society did not limit its viciousness to white on black relationships. As WyattBrown, Greenberg, Franklin, and others have pointed out, violence took place frequently between members of white southern society. This violence depended on the highly ritualized honor code that if violated could result in duels, fighting, and personal vendettas. Violence informed and underlined all of the public actions of elite white males, and thus the slaveholding class was eminently more familiar and predisposed to violence than their northern counterparts. As the overarching paradigm of southern culture, honor remains the best way to understand Confederate military strategy.

Determining the extent of southern honor's influence during the war requires understanding what actions and beliefs allowed southerners to express their credentials as honorable men. Many historians argue that southern gentlemen emphasized courage, aggression, pride, a severe disdain for cowardice, and an exaggerated display of masculinity as manifestations of their honor. Impugning any of these values typically resulted in violence, often through brawling or dueling. This thesis argues that the values of aggression, courage, and Confederate commanders' need to protect their honor and masculinity shaped the operations of Confederate armies. The battles and campaigns of the Civil War reveal the markers of honor-driven behavior. The historical record of Confederate leaders' decision making reflects the ways their cultural values affected their battle and campaign behavior. For example, the personal aggression that shaped operational or tactical-level decisions produced a consistent pattern of Confederate field commanders initiating contact with the enemy or pursuing Union forces at a higher rate 
than their Union counterparts. However, to separate this cultural aggression from Confederate commanders' expected aggressiveness in the context of battlefield maneuver, the thesis also explores European tactics and more orthodox battlefield maneuver. While honor is the primary focus of this work, Confederate officers made decisions based on other factors, including military education, experience, and personal character. Battlefields during the nineteenth century were places of complexity and confusion. Fear, hunger, field conditions, personal motivations, chance, the "fog of war," and technology all influenced the behavior of soldiers and their officers during battle. This thesis acknowledges the complexities of warfare while focusing on one specific, and vital, factor shaping the behavior of Confederate commanders: honor.

To evaluate the effects of aggressive tactical, operational, and strategic decisions, the thesis scrutinizes the course of the Civil War's campaigns. To that end, it divides the war into two distinct phases: the Confederacy ascendant (opening moves to Gettysburg and Vicksburg) and the tide turned (Overland Campaign to the war's end). In each of the phases, the thesis provides examples of Confederate commanders whose cultural background influenced their conduct, and offers battlefield examples of their aggressiveness, courage, and masculinity. It also examines commanders' efforts to avoid actions that might gain them the moniker of coward and how such concerns changed the way they led their men. The last of these points is particularly enlightening for understanding the role of southern culture in battle. For antebellum southern men, the social stigma associated with cowardice was a source of great shame. With the Confederate states at war, southern gentlemen suddenly had a national stage to prove their courage and masculinity in battle. As Southern aristocrat and Confederate colonel 
James B. Griffin wrote to his wife, explaining his desire to prove his masculinity, "I have so far never had the fortune to be engaged with the Enemy - I hope however, if it shall ever be my fortune to be engaged with them, that my conduct will be such, that if I do not merit your praise, will not cause you to feel ashamed." ${ }^{2}$ Such motives shaped the behavior of southern commanders on campaign and resulted in a demonstrable difference in officer casualty rates between the two armies, in deaths of high ranking commanders, in the tendency of officers to overexpose themselves and their men to fire, and in a disdain for retreat. In effect, the cultural values of the Confederate officer class reflected the society-wide attachment to the heroic warrior, often at the expense of military common sense and the lives of Confederate soldiers.

Despite the outcome of the Civil War, Confederate commanders have a historical reputation for being more effective than their Union counterparts. But despite examples like Robert E. Lee and Thomas Jackson, were Confederate commanders more effective than their Union counterparts? Evaluating the South's conduct of the war through a cultural lens inevitably leads to comparisons between the effectiveness of the two sides. The thesis will explore whether the Confederacy's commanders' adherence to their cultural norms helped or hurt their military's chances on the battlefield. However, the thesis does not simply summarize the already well-worn historical debate over Confederate battle tactics, but locates the cultural imperatives that influenced those tactics. Much of the research about Confederate tactics focuses on the South's quest for a "decisive battle" and argues that Confederate commanders wasted their meager resources on the offensive, when defensive actions and guerrilla fighting might have sustained their efforts longer. This thesis approaches this debate obliquely, without passing judgment on 
either argument. Instead, it shows how southern antebellum cultural patterns shaped the Confederate war effort. This discussion does not seek to answer whether the Confederacy conducted the war in a manner that maximized its armies' effectiveness, but instead asks how cultural values ultimately impacted battlefield performance. In order to understand how southern antebellum cultural uniqueness shaped Confederate commanders the thesis evaluates how southern forces performed differently than their Union opponents because of their cultural background. This discussion also contains a summary of the prevailing military patterns in the Western world, and how Napoleonic methods of warfare manifested themselves in both Union and Confederate armies.

Beyond looking at the campaigns, finding evidence of how culture effected Confederate operations involves examining more directly the men making the decisions. The written record of the Confederate officer corps opens a window into their motivations and emotions. Many Confederate officers who survived the war, and many who did not, left a record of memoirs, letters, diaries, and other primary documents that discuss their emotions, decisions, and thought processes on the battlefield. These writings expose the main cultural paradigms of southern honor culture. Did officers write about courage? Did they talk about attacking the enemy for honor's sake? What was the role of aggression on the battlefield? Was guerrilla warfare acceptable, or did it violate notions of gentlemanly conduct? Did fear of cowardice motivate their decision making? Was there a link between masculinity and battlefield performance in the minds of these men? These questions all speak to the motivations of the Confederate officer corps. Many more qualified works, especially James McPherson's For Cause and Comrades: Why Men Fought in the Civil War, have examined what motived soldiers on both sides. ${ }^{3}$ This thesis 
expounds upon questions of motivation by exploring how deeply ingrained cultural values proved a guiding force in Confederate decision making.

Exploring the motivations and decisions of the Confederate officer class requires primary resources produced by men who were part of the unique culture explained by Wyatt-Brown and others. While the violence, racism, and brutality that characterized slavery in the Old South certainly affected the entire white male population, the slaveholding class will remain the primary focus of this work for several reasons. By and large, this class transitioned seamlessly from peacetime leadership roles to the wartime officer class. They possessed both the requisite social standing and cultural background to assume command and influence battlefield decisions. Officer class positions represented a birthright indicator of social status for these men, though many possessed prior military experience. Social status helped guarantee elite white men officer commissions and much of the junior officer corps were the sons of the elite planter class. ${ }^{4}$ The thesis also explores the military school tradition and how it shaped the South's militant culture, drawing on studies such as Long Gray Lines: the Southern Military School Tradition, 1839-1915 by Andrew Rod Jr. ${ }^{5}$

Establishing the antebellum South's unique attachment to violence naturally lends itself to studying the region's antebellum relationship to America's military and military schools. Elite white southerners enjoyed a strong affiliation with the United States' military and attended both northern and southern military schools. Before and during the Civil War, military schools furnished a large percentage of the Confederate military leadership. Thus, the thesis primarily explores the writings of officers who obtained the military rank of major or higher, in order to focus on men exposed to the hazards and 
duties of command on at least the battalion level. Such officers commanded units large enough to influence the course of a battle, and were usually well-schooled students of military theory and capable of independent decision making. Though the rank of major did not traditionally command a battalion (colonels, lieutenant colonels, and brigadier generals held that responsibility), majors could take such commands in extenuating circumstances. Moreover, majors represented the lowest rung of field officers and were valuable members of any army's general staff. Still, the thesis focuses on the writing of men who made military decisions above the rank of major: colonels, generals, and other key decision-making officers who affected the course of battles as a result of their actions. Such officers exercised command roles and proved among the most prominent leaders of the antebellum southern elite. Their writings thus exist at the intersection between social and military distinction.

Along with primary documents produced by the southern military elite and secondary works on southern culture, this thesis employs a third set of historical data: the statistics of war. Despite recent revisions to the overall number of war dead, our statistical knowledge of battlefield casualties has changed relatively little since the 1860s. ${ }^{6}$ Examining the casualty data of the war comes with its own set of issues, specifically missing records from some southern states, but that does not preclude their effectiveness for examining military tactics. This is especially true of battle-by-battle casualty records and the records of specific regiments. By examining these sources and looking at the conduct of battles, this thesis seeks the statistical markers of southern antebellum honor culture. These sources answer particular questions about the nature of Confederate battlefield strategy: were Confederate armies more likely to attack? Did 
Confederate units experience high casualties as a result of their cultural attachment to aggression? Were Confederate officers killed or wounded at a higher rate? The thesis also applies advanced mathematical combat calculations like force ratios to Civil War battles. Force ratios are derived by comparing the number of men present on the battlefield for each army and the relationship between army size and casualties incurred. ${ }^{7}$ These types of calculations, which have recently become more common in military histories, enable a reexamination of Confederate and Union performance on the battlefield. Thus, the thesis combines the words of the Confederate officer corps and a data-driven approach to understand more fully how antebellum honor culture shaped the experiences of Confederate armies.

The Confederate military, led by the South's antebellum social elite, was deeply influenced by the region's heritage of honor. Living in a society culturally distinct from its northern counterpart, white southerners emphasized aggression, violence, masculinity, bravery, and a virulent disdain for cowardice. When the South transitioned from peace to war, the cultural paradigms of the southern elite moved seamlessly from guiding plantation life to running a military machine. This work determines how the culture of the antebellum South influenced Confederate military decisions by evaluating the voices of the region's military leadership and the statistical outcomes of the war's battles. Examining the cultural context and statistical consequences of Confederate commanders' military decisions shines new light on the nature of the Confederate war effort. Combining these three methods of historical inquiry shows how the South's antebellum honor culture helped shape the Confederacy's battlefield performance. Confederate 
officers lived and fought each day governed by a code of honor instilled in them as children, and their beliefs helped shape the Confederate military's performance.

${ }^{1}$ Bertram Wyatt-Brown, Southern Honor: Ethics and Behavior in the Old South (New York: Oxford University Press, 2007); W. J. Cash, The Mind of the South (New York: Vintage Books, 1941); Kenneth S. Greenberg, Honor and Slavery: Lies, Duels, Noses, Mash, Dressing as a Woman, Gifts, Strangers, Humanitarianism, Death, Slave Rebellions, the Pro-Slavery Arguments, Baseball, Hunting, and Gambling in the Old South (Princeton: Princeton University Press, 1996); and John Hope Franklin, The Militant South, 1800-1861 (Chicago: University of Illinois Press, 1984). See also: Ira Berlin, Many Thousands Gone: The First Two Centuries of Slavery in North America (Cambridge: The Belknap Press of Harvard University Press, 1998); Drew Gilpin Faust, Southern Stories: Slaveholders in Peace and War (Columbia: University of Missouri Press, 1992); David Hackett Fischer, Albion's Seed: Four British Folkways in America (New York: Oxford University Press, 1989); Elizabeth Fox-Genovese, Within the Plantation Household: Black and White Women of the Old South (Chapel Hill: University of North Carolina Press, 1988); Eugene D. Genovese, Fatal Self-Deception: Slaveholding Paternalism in the Old South (New York: Cambridge University Press, 2011) and The Political Economy of Slavery: Studies in the Economy and Society of the Slave South (Middletown: Wesleyan University Press, 1989); and Stephanie McCurry, Masters of Small Worlds: Yeoman Households, Gender Relations, \& the Political of the Antebellum South Carolina Low Country (New York: Oxford University Press, 1995).

2 Judith N. McArthur, A Gentleman and an Officer: A Military and Social History of James B. Griffin's Civil War (New York: Oxford University Press, 1996), 147.

${ }^{3}$ James M. McPherson, For Cause and Comrades: Why Men Fought in the Civil War (New York: Oxford University Press, 1998). See also Chandra Manning, What This Cruel War was Over: Soldiers, Slavery, and the Civil War (New York: Alfred A. Knopf, 2007); and Gerald F. Linderman, Embattled Courage: the Experience of Combat in the American Civil War (New York: Free Press, 1987).

${ }^{4}$ The younger generation of the elite social class in Virginia, and their experience before, during, and after the war is the focus of Peter S. Carmichael, The Last Generation: Young Virginians in Peace, War, and Reunion (Chapel Hill: University of North Carolina Press, 2005). Though they rarely held the command positions, their experience will be touched on in my evaluation of Confederate courage and disdain for cowardice, and how casualty lists reflected those cultural paradigms across the Confederacy.

${ }^{5}$ Rod Andrew Jr., Long Gray Lines: the Southern Military School Tradition, 1839-1915 (Chapel Hill: University of North Caroline Press, 2001).

${ }^{6}$ J. David Hacker's "A Census-Based Count of the Civil War Dead" Civil War History, 57, (December 2011) focuses on census data to revise previously low estimations of war casualties.

${ }^{7}$ See Chapter 3 for further discussion of force ratios and how they are calculated. 


\section{CHAPTER 1: MOONLIGHT, MAGNOLIAS, AND MILITARISM: THE ANTEBELLUM SOUTHERN HONOR CULTURE}

In his last published novel, The Reivers, southern writer William Faulkner departed from many of his more complicated stylistic techniques and wrote a lighthearted and satirical work. Despite its often flippant tone, the novel has a moment of seriousness, when the main character's grandfather lectures him for stealing his car: "A gentleman can live through anything. He faces anything. A gentleman accepts the responsibility of his actions and bears the burden of their consequences."1 The story's grandfather hearkens back to a forgotten past, reminding his young ward that southern men were once believed to be men of honor, bound by implied codes of conduct that regulated and governed social interactions. For the grandfather, this semi-legendary time, the South's heyday, took place before the destruction wrought by the Civil War, when in popular southern memory, stately manors dotted an idyllic countryside populated by lordly Christian gentlemen and irreproachably pure women. The slaves adored their paternalistic masters, who disciplined their servants from love rather than cruelty. In this vision of the South, moonlit paths wound under yawning magnolia trees to beautifully palatial plantation homes, and noble and graceful gentlemen who recalled the great feudal barons of medieval England led a smiling and happy populace. Despite its quixotic nature, this imagining of the South remained enduring and strong. The grandfather Faulkner created represented southerners who longed for a return to an impossible vision of the Old South, forever destroyed by their hated Yankee foe. ${ }^{2}$ 
The American Civil War (1861-1865) proved an unmitigated disaster for the Confederate States of America. As many as four hundred thousand southern men became war casualties, 18 percent of white males eligible for military service died, and Yankee armies occupied the South. ${ }^{3}$ Together, the Confederate states spent 2.1 billion dollars on the war, its enslaved black population secured freedom with the aid of Yankee bayonets, cotton production plummeted, income fell 40 percent per capita, and battlegrounds scarred once fertile lands from Virginia to Texas. ${ }^{4}$ But the South's intellectual and cultural elite remained unbowed and defiant. Southern gentlemen across the defeated Confederacy took solace in a phrase they repeated over and over, "all has been lost save honor." Their defiance sprang from a longstanding southern attachment to honor that shaped their unique regional culture. Equally important, these antebellum cultural values also influenced how southern gentlemen directed the Confederate war effort, military strategy, and tactics. Focusing on the Confederate officer corps, which constituted the prewar southern aristocracy, this study argues that Confederate officers' cultural background helped shape their military decisions. The southern antebellum elite blended their prewar cultural paradigms with prevailing European military practices, which together governed Confederate officers' military strategies and decisions.

Despite four years of war, the destruction of their society, and the harsh realization of defeat, the southern elite remained defiant because of their antebellum culture of honor and conceptions of honorable defeat. Wars are not conducted in a vacuum; generals lead armies and make choices based on values, rationalizations, and paradigms arising from the cultures in which they are educated. ${ }^{5}$ The Confederate officer corps was the product of a unique plantation culture whose members viewed honor, 
courage, justice, and masculinity as the highest ideals. ${ }^{6}$ George Grenfell, a Confederate colonel during the war, explained this cultural obsession with violence and bravery: "The only way in which an officer could acquire influence over the Confederate soldier was by his personal conduct under fire. They hold a man in great esteem who in action sets them an example of contempt for danger; but they think nothing of an officer who is not in the habit of leading them. In fact such a man could not possibly retain his position." Understanding how southern culture affected Confederate military tactics begins by detailing what made antebellum southern culture unique.

The United States, despite dynamic spatial growth, a burgeoning economy, and emergent international standing, was torn apart between 1861 and 1865 by internal divisions that arose long before the nation's descent into war. Cultural differences lay at the heart of the sectional divide, with the southern states embracing unique notions of honor, courage, and masculinity. These components of the South's peacetime honor culture shaped how the white southern elite conducted military operations during the Civil War. Inherent in a study examining the culture of a social group lies the dichotomy between how the group viewed itself and how it actually functioned. The antebellum southern aristocracy proved no exception to this gulf between perception and reality because the group invested heavily in the creation and promulgation of its own myths, standards, and paradigms. Examining the disconnect between what southern gentlemen believed themselves to be and how they actually lived offers a clearer picture of the southern elite before and during the war.

The southern aristocracy's cultural heritage differed significantly from its northern counterpart for several reasons. Both northern and southern white cultures 
shared a common British heritage, but southerners believed they descended from the English aristocracy. ${ }^{8}$ The southern elite saw their intellectual, spiritual, and ancestral predecessors as the Royalists who fought in the English Civil War of 1642-1651. The war pitted Puritan Parliamentarians, known as Roundheads, against Anglican Royalists, or Cavaliers, and ended in 1651 with the Royalist defeat at the Battle of Worcester. The Roundheads deposed the English monarch, Charles I, and established a Puritan government led by Oliver Cromwell. Cromwell's short-lived reign helped shape the antebellum cultural divide in the future United States. Contrasting themselves to the Puritan descendants of Massachusetts and the North, southern aristocrats identified with the Cavaliers, the losing side in the English Civil War. Later historians have found deeper genealogical links between the southern population and Irish and Scottish immigrants, but the southern elite's identification with Cavalier culture shaped their behavior. ${ }^{9}$

The mystique of Cavalier society occupied a significant place in the minds of southern gentleman, who embraced concepts of chivalry, fidelity, and honor that they believed the Cavaliers exemplified. ${ }^{10}$ Southern planters traced their ancestry to the Cavaliers, who in defeat and exile settled and populated the tidewater states of Virginia, Maryland, and the Carolinas, far removed from the Puritan colonists to the north. As the southern states grew in population and expanded westward, speculators, settlers, and surveyors took their cultural heritage with them, spreading their culture far from the Atlantic coast. ${ }^{11}$ Much like the English aristocracy, the planters' lordly culture centered on the manor house and the land that furnished their wealth. ${ }^{12}$ By the end of the seventeenth century, the southern plantation culture relied on the use of slave labor and the violent repression of enslaved people to prevent rebellions and escapes. ${ }^{13}$ The 
violence and racism intrinsic in this slave society helped reinforce southern whites' cultural proclivity for vigilance and aggressiveness, a pattern of behavior justified by slaves' status as property. ${ }^{14}$ This plantation culture based on collective memory and landbased wealth, moved west with slavery, shaping southern life from Virginia to Texas. The cultural homogeneity of the South gave the region's elite a cohesiveness and shared sense of identity, particularly after the rise of an antagonistic abolitionist movement in the North after 1830 that southerners attributed to that region's Puritan origins. In the decades before the outbreak of the Civil War, the South reveled in its violent national character. Living in a culture characterized by its relationship to violence, white southern men, regardless of class, believed that as military men they surpassed their northern neighbors. White southerners reinforced this belief through their daily attitudes and actions, and even foreign observers commented on the "fiery blood of the south." 15

The South's culture encouraged a duality in the southern elite's behavior and outlook. On one hand, southern gentlemen, modeling the behavior of the Cavalier aristocracy, celebrated courtesy, chivalry, courage, paternalism, piety, hospitality, deference to authority, kindness to women, contempt for cowardice, honesty, and loyalty. ${ }^{16}$ But beneath the exaggerated attachment to genteel standards of conduct lay an undercurrent of violence, racism, and aggression, with southern white men prone to baser pursuits, such as drinking, hunting, gambling, brawling, having sexual relations with slave women, and lying. ${ }^{17}$ Violence in the pursuit or defense of honor proved a key marker of the planter class, and their self-image and behavior celebrated assertions of masculinity. At the outbreak of the Civil War, a Richmond newspaper cited these violent cultural paradigms to explain why the war would result in a quick southern victory: "The 
familiarity of our people with arms and horses gives them advantages for aggression .... Ten thousand Southerners, before the Yankees learnt to load a gun, might [be] marched to Boston without resistance." 18

White men who embraced the honor culture of the antebellum South depended on communal opinion to determine their status and were acutely aware of how their peers viewed them. ${ }^{19}$ They met perceived threats to their honor with violence, and disagreements frequently ended in duels, brawls, and other highly public forms of violence that reinforced the masculinity of the offended parties. ${ }^{20}$ A northerner described "the central trait of the "chivalrous Southron" as "an intense respect for virility. If you will fight, if you are strong and skillful enough to kill your antagonist, [then] you can govern or influence the common herd. ${ }^{, 1}$ Southern white men also felt the need to assert their credentials as honorable men in regional, state, and national contexts. The honor culture always informed their decisions, even when they dealt with northerners who did not share the South's honor culture. Most famously, on May 22, 1856, South Carolina Congressman Preston Brooks brutally caned Massachusetts Senator Charles Sumner on the floor of the United States Senate after Sumner attacked slavery and insulted Brooks's uncle, Senator Andrew Butler, thereby impugning his honor. ${ }^{22}$ Northerners condemned the caning, but southerners applauded it, highlighting the violent redress that insults to southern honor demanded.

The white men who embraced the honor culture and later became the elite of the Confederate military represented a small fraction of the overall population of the South — the eleven states that formally seceded from the Union and the three additional slave states that did not secede. Before the war, the southern elite governed fourteen states - 
Alabama, Arkansas, Florida, Georgia, Kentucky, Louisiana, Maryland, Mississippi, Missouri, North Carolina, South Carolina, Texas, Tennessee, and Virginia — and played a central role in the governance of the country. In 1860, the population of the eleven future Confederate states numbered about 9.1 million, of which 3.5 million were enslaved blacks. ${ }^{23}$ The master class dominated these states economically; by 1860 , slaveholders controlled 90-95 percent of all agricultural wealth in the South. ${ }^{24}$ The number of slaveholders in the South numbered slightly more than three hundred thousand, 85 percent of whom owned nineteen slaves or less. ${ }^{25}$ This category of slave owners managed small to medium-size farms and often supplemented their labor force during the harvest season by hiring poor whites and additional slaves. Southern aristocrats who owned more than twenty slaves held most of the wealth of the slaveholding class. Numbering about forty three thousand in 1860 , these men were not only the political elite but the social leaders of the master class. ${ }^{26}$

However, using these numbers to equate slaveholders with the Confederate officer group is problematic. In the Civil War, officers commissioned as majors or colonels exercised command positions at the regimental level. They constitute a major part of this study because these men exercised command duty that required tactical knowledge and could influence the outcome of a battle. Still, the onus of command largely fell on generals, making them the primary focus of this work. The Army of Northern Virginia averaged sixty eight thousand soldiers over the course of its ten largest engagements, with officers constituting about 3.5 percent of the total. ${ }^{27}$ In contrast, the richest planters, those holding twenty or more slaves, represented about 15 percent of all slaveholders. However, this calculation assumes that all officers owned slaves, and all 
slaveholders served in the Confederate military, neither of which was accurate. Instead, these numbers offer an approximation of available officer positions, and the small percentage of the population that could potentially attain command roles. Though southern slaveholders did not hold a complete monopoly of the command positions in the Confederate forces, these numbers demonstrate the difficulty that non-elites faced in moving higher in the ranks based solely on merit. In this society, wealth and social status served as vehicles to public office and wartime leadership. The small percentage of positions available to satisfy the honor of a southern gentleman made competition for these positions intense, and aristocrats could count on their promotion to leadership roles because of their place in the prewar society.

Officers often outfitted and recruited their own regiments, especially early in the war. Confederate commanders held their positions because they belonged to the social elite, and their aristocratic status implied military competency. ${ }^{28}$ Since Confederate units, unlike Union forces, were replenished by new recruits and not phased out after costly battles, many of these units remained intact throughout the war. This fact, coupled with the Confederate practice of democratically electing officers, often meant the "best" men received and held important command positions throughout the war, and that the relatively few staff officer posts and generals' commissions remained in the hands of elite southerners. Non-commissioned officers and the lower levels of the chain of command (lieutenants and captains) were often the younger sons of elite planters serving to prove their manhood, while the older generation led the armies. ${ }^{29}$ As one young officer wrote to his mother: "Tell father ... he may flatter himself of having a son who though raised in the lap of luxury, has passed through the most infernal ordeal of privations ... \& of 
misery without a murmur., ${ }^{30}$ In short, southern antebellum elites transitioned seamlessly from prewar positions of social and political control to wartime positions of command, ensuring that the South's antebellum honor culture influenced Confederate military operations. Southern peacetime leaders brought cultural values to their military service that shaped their behavior on the battlefield.

This transition represented an essential component of the growth of the Confederate military, and can be confirmed statistically. While no records exist that offer firm numbers detailing slaveholder participation in Confederate forces, samples provide strong clues. In Soldiering in the Army of Northern Virginia, Joseph T. Glatthaar samples six hundred random soldiers from the Army of Northern Virginia, sorting them by age, state or country of origin, year of enlistment, marital status, economic class, slave ownership, and a host of additional criteria. Despite the problems inherent in statistical sampling, the incredible amount of detail Glatthaar accumulates enables him to draw reliable conclusions. In terms of economic class, Glatthaar finds that the upper class represented 35 percent of the sample, despite constituting 20 percent of the prewar southern white population. ${ }^{31}$ This upper class belonged almost entirely to the slavocracy, with 91 percent of the elites sampled owning slaves before the war. ${ }^{32}$

These statistics offer a clear picture of the elite's wartime participation. During the antebellum period, one in every four (25 percent) southern households owned slaves, but in Glatthaar's sample four of every nine soldiers (44 percent) lived in slave-owning households before the war, a 19 percent difference. ${ }^{33}$ Measured both by economic class and slaveholding, the Confederate military was a product of the antebellum South's plantation culture. In particular, slaveholders made up 37 percent of the sample, revealing 
the willingness of the Old South's planters to fight. ${ }^{34}$ Though both sides resorted to various methods of conscription, the Confederate states enjoyed a white male enlistment rate of 17.3 percent, nearly double the white Union enlistment rate of 9.5 percent. ${ }^{35}$ An astonishing 24 percent of Mississippians served in Confederate armies compared to 15 percent of Illinoisans, the highest rate of participation in the North. ${ }^{36}$ Statistically, the Confederacy demonstrated a wartime zeal consistent with the cultural impetus for bravery and service demanded by antebellum instead of honor. White southerners transferred notions of personal honor, defense of the family, and assertions of manliness to the body politic. As General Lafayette McLaws, of Georgia, wrote, "I consider it a duty to my country, to my family and to humanity itself to use my utmost endeavor to free the South from the dominion of the North."37 The white South — and certainly the southern elite — rose up as a largely unified cultural entity to defend the Confederate states.

Other aspects of Glatthaar's sample reveal the economic and cultural characteristics of the officer corps. For example, officers had an average personal wealth of $\$ 6,322$ compared to just $\$ 1,299$ for enlisted men. ${ }^{38}$ More than one officer in every five had a personal wealth of more than ten thousand dollars, a number that dwindled to just one in every twenty-five enlisted men. ${ }^{39}$ Nearly half of all officers (49.5 percent) owned slaves, and a staggering 62.9 percent of all officers came from households that owned slaves before the war. ${ }^{40}$ Glatthaar's data shows that the officer class was a product of the plantation, affluence, and prewar success, and the southern military in general stood deeply committed to the defense of slavery and maintaining the region's cultural heritage. 
More than any other aspect of southern culture, violence ruled the lives of southern elites. Within their honor culture, southern gentlemen had multiple ways to express their status as "men of honor." However, elite men most commonly responded to insults to their honor through violence, which pervaded southern society, as gentlemen dueled, brawled, and feuded with one another, often over small slights. ${ }^{41}$ Moreover, the honor culture and the violence it engendered shaped the behavior of southern white men outside the upper crust. Poor whites shared in the elite's honor culture, and responded to insults to their honor as brutally as wealthy planters. However, the two social groups differed significantly in their attitude toward the practice of dueling and brawling. Elite southerners, reinforcing their class hypocrisy, insisted that dueling was a barbarous and uncouth activity, all the while engaging in violent and often longstanding feuds. ${ }^{42}$ The southern elite publicly labeled dueling an uncivilized indulgence, but participated wholeheartedly nonetheless. Dueling also prevailed in the ranks of the local militias, which southern gentleman joined to gain military rank in a society in which titles of nobility did not exist. Jefferson Davis, who served in the Mexican-American War, and more famously became president of the Confederacy, explained that southerners had:

[A] fondness for military titles and displays .... [Outsiders] have commented on the number of generals, and colonels, and majors all over the [southern] States. But the fact is, we are a military people .... We are not less military because we have had no great standing armies. But perhaps we are the only people in the world where gentleman go to a military academy who do not intend to follow the profession of arms. ${ }^{43}$

Military rank became an important currency of honor, cementing the link between the violent activities of the military and social prestige. The social display of militia units, and their often costly uniforms and equipment, further emphasized that military rank belonged to those of standing who could afford to be warriors. ${ }^{44}$ In contrast, lower class 
white men, eminently concerned with their sense of honor, openly accepted violence as a common part of their discourse. Less concerned with image, they reveled in this brutality without pretending otherwise. Still, all southern white males shared the ethic of honor. ${ }^{45}$ This widespread sense of honor became an important part of the Confederate military. The elites in the Confederate high command used honor to guide their military decisions and strategies, while the lower classes that made up the Confederacy's enlisted elements fought bravely and tenaciously because of their attachment to the honor culture.

Honor influenced the behavior that led to many violent interactions on and off the plantation, but the South's elite also emphasized gentility, particularly in their interactions with white women. Indeed, the South's imagined ideal of womanhood stood far from the carefully cultivated racist brutality of the slave-master. ${ }^{46}$ White women represented the purer ideals of the southern elite, despite the fact that both men and women shared genteel qualities. Southern elite women strived to be gentle, quiet, meek, pure, and chaste, and after marriage to be mothers, household leaders, matrons, and exemplars of southern virtue. ${ }^{47}$ The ideal of southern white womanhood, moreover, played an important role in the battlefield and strategic decisions of the Confederacy's military leadership. Confederate commanders conceptualized the defense of the South in highly gendered terms. They viewed defending the honor of the South as deeply intertwined with the idea of defending the South's white female population. ${ }^{48}$ Southern white men, both elite and poor, fought to defend their households and the virtue of the women within. The specter of threatened white womanhood united southern white males regardless of social class. ${ }^{49}$ As James B. Griffin wrote, "For while men can manage to work for themselves, and can fight the battles of their Country if necessary, Females are 
very dependent. ${ }^{, 50}$ Union invasions of southern territory demonstrated the inability of the Confederacy to defend itself, and by extension, threatened the masculinity of the southern patriarchy. Conversely, southern invasions of Union territory reinforced the notion that northern armies were incapable of defending their households and women.

The South's unique approach to violence resulted from more than its attachment to honor. In part, the violent character of southern men was a product of their cultural memory of violence. During the long wars the United States waged with Native Americans, southern men served in the regular army, local militias, and defended the region from hostile native raiders. Though the South's experience of Indian warfare paralleled that of the North, southerners never lost their sense of being an embattled populace. ${ }^{51}$ Militias and military training remained an essential aspect of local governance, believed necessary to defend southern settlements from Indian attack (at least until the 1830s) and slave unrest. ${ }^{52}$ To keep slaves from escaping, and to bring back those who attempted to flee, slave patrols ranged through the South. Locally based and drawn from militia units that provided the structure and resources necessary for the job, the patrols drew men from all classes, providing adventure and relief from the tedium of everyday life. ${ }^{53}$ The patrols were inherently violent, straddling the line between civil service and military operation, and kept the South in a constant state of near-military preparedness.

The racist slave system of the antebellum South brutalized African Americans, while normalizing and desensitizing whites to the violence they perpetrated. Race-based slavery rested on the assumption that the enslaved black population was racially inferior, and during the Civil War, Confederate soldiers used this racism to justify atrocities 
against black soldiers in Union armies. ${ }^{54}$ Maintaining and protecting slavery required consistent and conspicuous violence. ${ }^{55}$ To prevent runaways, cow enslaved people, and reinforce their subservient status, whites turned to violence. Slave patrols, militia service, memory of Indian wars, and a cultural attachment to hunting together bred a violent and paranoid society, whose population feared the non-white elements that surrounded them. Southerners serving in the Confederate military believed themselves better prepared for war than their northern counterparts. More important, the southern elite's sense of honor, inability to accept defeat, and aggressive response to provocation animated the Confederate command. White southern culture, hardened by the rigors of maintaining slavery, entered the war with a distinct advantage. A cultural attachment to violence permeated the Confederate military structure, while elite commanders' aggression and inability to accept defeat drove decision making.

The ideal of the chaste, virtuous, and unblemished southern white woman reinforced notions of masculinity among southern white males, who considered men who could not protect their households weak, dishonorable, and powerless. In a society focused on honor and masculinity, protecting women became vitally important. As political tensions between the North and the South deepened before the Civil War, southerners increasingly portrayed the South as a female entity. By rhetorically linking the region and its white women, southern men reinforced their self-image as defenders of threatened womenfolk. ${ }^{56}$ This tactic garnered strong support in the South and helped forge a sense of unity among the white population. Describing the South in gendered terms also made threats by the North significantly more ominous. During the Civil War, southern leaders frequently employed this rhetorical trope, convincing many Confederate 
officers to defend the South with the same energy they defended their women and households because their own honor was at stake. As soldier John Dale wrote to his wife: "You said that you didn’t want me to come home unless I came in honor. I never will come [back] unless I come that way." ${ }^{57}$ Confederates, in short, equated the need to defend their homeland with the defense of southern white women's honor. Allowing northern armies to run roughshod over southern territory constituted a violation of southern virtue, masculinity, and honor and thus had to be met with violent retribution. When Confederate commanders sensed such an insult, they often conducted rash or strategically unwise attacks to stop the Union forces intent on pillaging or "raping" southern territory. This cultural lens also sheds light on southern military leaders' consistent interest in fighting set-piece battles. ${ }^{58}$ Their pursuit of conventional battles, rather than guerrilla tactics, also reflected the southern code of masculinity. Confederate guerrillas certainly existed, but the South's main field armies, led by proud gentlemen, preferred to fight openly and "fairly." ${ }^{, 59}$ Men gained honor when they defeated their equal on the field of battle; thus Confederate officers had strong cultural reasons to seek major engagements. Likewise, Confederate invasions of the North reflected southerners' cultural imperatives to reciprocate the damage done to their honor by northern invasions. Invading and raiding northern territory represented an attempt to wage cultural warfare in addition to achieving more practical and traditional military objectives.

Religion represented a central element of the antebellum South's elite honor culture. The aristocracy's relationship to Christianity and religion's role in the mythos of the South helped guide the actions of the southern elite. Southern white Christians, despite a diversity of denominational affiliations, viewed their faith's militaristic past as a 
blueprint for their behavior. Southern Christian military men like the fanatical Stonewall Jackson loom large, but his extreme piety was neither the exception nor the rule. ${ }^{60}$ Instead, Christianity's peacetime pervasiveness often entered the military vernacular through the idealized "miles Christi" who drew his bravery and courage from his faith. ${ }^{61}$ Throughout the war, this image remained popular and influential among elite and lower levels of white southern society. Religion proved a powerful motivator for Confederate armies, but it served a similar role in the North as well. ${ }^{62}$ Thus, though religion was important, more secular cultural paradigms often have greater power to explain southern military behavior.

The class divide in white antebellum southern society helps explain the relationship between the region's cultural values and Confederate military tactics. Southern gentlemen at the uppermost portion of the antebellum slavocracy were extremely conscious of their social status. Poor whites, who provided the bulk of the enlisted men in the Confederate armies, represented the largest free social group in the region. To differentiate poor whites' unique place in the southern hierarchy, their social betters as well as their slaves, referred to them as "crackers." ${ }^{63}$ The elite dominated military command, but the lower classes carried out the culturally influenced military orders of their leaders. ${ }^{64}$ Elite and poor white males, despite significant differences in wealth, access to land, social position, dialect, dress, and political influence, were inextricably linked by the honor culture of the South. Rich and poor white males shared a collective need to reinforce their status as honorable men, though each group defined the concept differently. ${ }^{65}$ Among the elite, the concept of honor existed alongside genteel notions of refinement and dignity. ${ }^{66}$ Poor whites lacked this attachment to gentility, but 
they were no less aware of their position as honorable men and responded to slights to their honor like their social betters. Despite the economic gulf that separated the social classes, antebellum southern white men showed an acute understanding of their own and their region's honor.

Southern cultural values shaped Confederate military operations, but southerners also embraced prevailing European military practices. ${ }^{67}$ In the nineteenth century, military theory originated in Europe, with two primary figures, Napoleon Bonaparte and Antoine-Henri Jomini, shaping American military thought in $1860 .{ }^{68}$ Before the Civil War, military schools in the United States, when not teaching science, math, surveying, and a host of other academic subjects, taught the exploits of Napoleon, the most important and impressive general during the most significant set of European wars since the seventeenth century. Born in Corsica in 1769, Napoleon revolutionized European warfare during a time of great political and social instability in Europe. In the late eighteenth and early nineteenth centuries, Napoleon helped transform the French army from a bastion of aristocratic privilege to an organization in which professionalism and ability were hallmarks of success. ${ }^{69}$ Napoleon owed his meteoric rise from military schoolboy to emperor of most of Europe, to his ability to capitalize on these changes. After the brutally indecisive religious wars of the seventeenth century, military, political, and social theorists sought to restrain the violence of warfare, often by improving military professionalism. ${ }^{70}$ The age of the Enlightenment reduced military maneuvers to paradeground spectacles in which the belligerent powers engaged in battles that were neither decisive nor ruinously expensive in men or material. ${ }^{71}$ Despite the successes of a few generals who saw the value of fighting battles to decide conflicts, military and political 
leaders showed a collective disinterest in widening the scope of war. John Churchill, the Duke of Marlborough, proved during the War of Spanish Succession (1701-1714), as did Frederick the Great during the War of Austrian Succession (1740-1748), that battle could end the fruitless sieges, marches, and maneuvers of eighteenth century warfare. Despite the legendary accomplishments of Marlborough and Frederick, most European generals eschewed "total war" for a narrower "limited war."

As a young student of military history, however, Napoleon took note of Marlborough and Frederick's strategic goals. The French Revolution opened opportunities for promotion to the officer corps not previously available to skilled, but non-noble Frenchmen. The Revolution also swept away the hated conscription of the royalist army, and replaced it with a volunteer force motivated by patriotism. ${ }^{73}$ Napoleon used these highly motivated if poorly trained forces and unleashed them on European armies still chained to conscription and captained by unimaginative officers. Instead of limiting his objectives and preserving his armies by avoiding battle, Napoleon actively pursued decisive engagements to gain political goals through his campaigns. ${ }^{74}$ His impressive list of victories — at Marengo (1800), Ulm (1805), Austerlitz (1805), JenaAuerstedt (1806), Wagram (1809), and Borodino (1812) — established Napoleon as the master of the set-piece battle and a dominant strategist. Despite his disastrous invasion of Russia and defeat at Waterloo in 1815, Napoleon died in 1821 with his military reputation intact, in part because military theorists made learning about his campaigns required curriculum for generations of rising officers. ${ }^{75}$

The chief military theorist of the post-Napoleonic era was Antoine-Henri Jomini. He authored several works on strategy, tactics, and maneuver warfare, including The Art 
of War, which examined Napoleon's campaigns as exemplars of the decisive battle approach to war. Jomini, like many of the military thinkers of this era, absorbed Romantic Age notions of science, progress, and rationalism. He believed that battle, though essentially a form of art, was governed by a series of scientific principles that military thinkers could control and codify. ${ }^{76} \mathrm{He}$ conceived of warfare as an equation that could be mastered and taught as long as officers accounted for unquantifiable variables, such as chance, uncertainty, and luck. This style of scientific warfare was epitomized by battlefield engagements in which the winning general applied these scientific principles more effectively, while avoiding bad luck or mischance. ${ }^{77}$ Napoleon's genius, according to modern scholars, lay in his organizational skills and far-reaching strategic insights. In contrast, nineteenth century theorists like Jomini downplayed Napoleon's impressive ability to organize, plan, and maintain campaigns, and focused instead on his ability to force and win battlefield engagements. Napoleon's tactical genius cannot be denied, but theorists like Jomini failed to recognize that his tactical innovations had become largely obsolete within his own lifetime. Battles rarely had lasting political consequences despite theorists' commonly held notions to the contrary. Even Napoleon's near perfect victory over Austrian and Russian forces at Austerlitz in 1805 had little lasting political impact. His foes raised a new coalition of nations against him within months. Still, military theorists working in Napoleon's shadow argued that battle could produce permanent political outcomes and they convinced later generations to emulate Napoleon. ${ }^{78}$ The allure of winning huge, set-piece battles convinced young military officers to engage one another in Napoleonic fashion, rather than looking beyond his tactics toward more 
innovative approaches. The result was a period of stagnated military thinking that lasted until the trenches of Europe in $1914 .^{79}$

Scholarly examinations of the evolutions in military history during the Napoleonic era rightly omit the United States because it was not an important military power. ${ }^{80}$ During these years, American forces battled Native American tribes, British incursions, and even landed forces in North Africa to combat the Barbary pirates, but the country remained a military backwater, albeit one determined to maintain the professional image, if not the size, of its military. Always afraid of a standing army, which they viewed as a tool of tyranny, Americans had little interest in paying for a military on the same scale as the European kingdoms. ${ }^{81}$ Instead, a nascent but minuscule frontier army and state militias absorbed military spending. The larger southern militias served a variety of purposes, not all of them military in nature. The regular frontier regiments combated Indian tribes, mapped and explored western territories, built forts, protected settlers, and performed a variety of frontier duties. ${ }^{82}$ Despite their utility, United States' frontier units had little in common with the professional forces of Britain or France - or for that matter with later Civil War regiments. The change from frontier security to Napoleonic-style battle and maneuver occurred slowly, but southerners eventually adapted their culture to European strategies and tactics.

Between 1815 and the Mexican-American War in 1846, the United States was involved in no major wars. Despite incursions into Spanish Florida, constant trouble with Indian tribes, and naval operations in the Atlantic and beyond, American forces gained no practical experience against European-style field armies. Without the opportunity to gain experience in combat, Americans turned to military schools to learn about European 
advances in combat. ${ }^{83}$ The United States Military Academy at West Point changed its curriculum in 1817 , emphasizing tactics, engineering, and the common procedures of modern European armies. West Point professor Dennis Hart Mahan pushed for the codification and standardization of American military professionalism, promoting European methods of military education and Jominian tactics. ${ }^{84}$ Between the 1820 s and 1860 southerners founded dozens of private and public military schools, aiming to attract a public deeply interested in military service and the ethos of the military man. ${ }^{85}$ The perception of the South as an armed camp allowed these schools to flourish, instilling several generations of students with militaristic notions of duty, honor, and courage, along with a practical education in military theory, science, and math. ${ }^{86}$ The success of military schools in the coastal states ensured the western spread of similar schools and their curriculums, reinforcing the South's broad militarism. ${ }^{87}$

By 1860, most American military officers were familiar with Jominian conceptions of battle. ${ }^{88}$ Almost to a man they believed that joining battle with an enemy's forces after maneuver could produce politically consequential victories that would limit the destructive scope of warfare. Officers from the North and the South learned from the same military texts, often side by side in the same classrooms, and they believed that maneuver and battle could decide a conflict quickly. Despite their confidence, however, the Civil War lasted four years and cost dearly in men, material, and wealth for two central reasons. First, Civil War armies were roughly the same size as the armies of the Napoleonic Wars, but armed with significantly more deadly weaponry. By 1860 rifled muskets capable of delivering more accurate fire at longer distances had supplanted the smoothbore muskets of the early nineteenth century. ${ }^{89}$ American Civil War commanders 
did not change the close-order tactics of the period to respond to the new weapons until late in the war, when they responded at all. ${ }^{90}$

Second, antebellum southern culture sustained the Confederacy after its military defeats. Measured by casualty rate, the combined Confederate losses at Gettysburg, Vicksburg, Atlanta, and the Wilderness rivaled the bloodiest battles of the Napoleonic Wars. Napoleon's crushing victories often brought his enemies to the negotiating table, but southern cultural values demanded that the Confederacy carry on the war effort, long after the South was financially and militarily exhausted. Even as the South's chances of a favorable outcome dimmed, southerners continued to believe in the Confederacy's ultimate victory, reflecting their cultural disinclination to surrender, admit defeat, or suffer the dishonor associated with these actions. ${ }^{91}$ By prevailing military standards, Union armies decisively defeated the Confederacy's forces at several battles, but southern values prevented white southerners from accepting this fact until late in the war.

Scholars have second-guessed the Confederacy's decision to fight a formal, European-style war almost since the Confederate government surrendered.${ }^{92}$ In particular, many argue that the South should have concentrated on raising and equipping guerrilla units to fight, avoiding pitched battles and major confrontations until the Union exhausted itself. ${ }^{93}$ But the central role of the South's honor culture in shaping Confederate military operations made these options unsuitable. Though Confederate war records reveals numerous instances of Confederate raiders and partisans, the amount of support the Confederate government gave them paled in comparison to what it spent on the South's conventional armies. The Confederate War Department in theory supported guerilla units, but Confederate leaders believed that the best chance for victory lay with 
the regular armies, and thus they committed the resources and manpower of the South to these forces. Critics of Confederate tactics believe that a guerilla war, and specifically a war in which the Confederate armed forces concentrated only when they had numerical superiority, represented the best course of action. ${ }^{94}$ Proponents of this theory argue that Confederate commanders should have fought a war in which they denied battle, and only attacked when they located isolated enemy units. This argument rests on the belief that after several years of bloody and inconclusive warfare, the Union would have ousted President Abraham Lincoln in the 1864 election and northern Democrats would gladly end the war.

However, several factors precluded this turn of events. First, the Confederacy could not have fought a guerrilla war for a prolonged period of time for ideological reasons. One of the Confederacy's greatest idols, George Washington, fought a war in which his main objective was avoiding total defeat, but the Confederacy could not have survived such tactics. In Lee Considered: General Robert E. Lee and Civil War History, historian Alan T. Nolan argues that Lee and his fellow generals could have worn down the Union with Washington-like tactics and preserved their own forces until the North gave up. ${ }^{95}$ But the Confederacy wedded itself to a conventional war when it declared Richmond the Confederate capital, thereby institutionalizing the necessity of controlling geographic and ideological strongpoints unviable in guerrilla warfare. ${ }^{96}$ As McLaws explained:

Our government has ... committed itself to the policy of concentration .... This venture is vast and promises the most ample return, and therefore before judging we must await results. If our armies can be fed, there is every reason to believe that victory will . . . crown our efforts, and our efforts will sooner be achieved than it would have been by the [defensive] policy. ${ }^{97}$ 
Conventional warfare demanded that the Confederate government hold and maintain its new territorial integrity. The South's initial victory at Bull Run in 1861 confirmed this as a workable strategy, and from that point the Confederacy operated within the framework of a conventional war.

Second, guerrilla war proponents ignore the South's political and cultural realities. The separate Confederate state governments would never have agreed to let their territory and homes be invaded and overrun by Union armies, even in the name of a coherent national strategy. Historian Gary W. Gallagher argues that the southern public clamored for aggressive action from their great generals, not Washington-like defensive tactics. ${ }^{98}$ Indeed, Washington hoped to survive long enough to create a nation, whereas the Confederates believed their states already formed the basis for a nation. The Confederacy fought a war characteristic of a modern nation-state, and only when faced with the destruction of Confederacy in 1865, did Jefferson Davis release Lee and Joseph E. Johnston's field armies to fight a hit and run guerrilla war, something that neither leader decided to follow.

Southern cultural and social values also played a marked role in pursuing the decisive battle. Even though the decisive battle doctrine predated notions of honor and masculinity in the Old South, it shared a central component, aggression, with white southern notions of honor. Historian Bertram Wyatt-Brown's Southern Honor explores the role of aggression in southern society during the antebellum period, frequently using Lee as an exemplar of southern behavior. ${ }^{99}$ He argues that aggression was central to conceptions of masculinity and honor in the Old South. Confederate generals and the white populace would not accept a strategy that robbed them of their honor or 
masculinity. Widespread guerrilla war involved Union armies occupying and violating the South, which would have emasculated the South's white male citizens. The decisive battle doctrine offered a preferable method of fighting because it allowed Confederate armies to defend aggressively their states and their honor.

Revisionist historians critical of Confederate strategy also argue that the vast size of the South lent itself to a defensive style of war. ${ }^{100}$ They argue that Confederate armies could strike and then "disappear" into the vast southern landscape with little difficulty. In one respect, these scholars are correct. The combined territory of the Confederate states was vast, totaling 733,144 square miles, an area equal to a large swath of western Europe, a detail that Confederate agents at European courts consistently noted, especially when discussing the South's military chances. ${ }^{101}$ But the South's large square mileage masked the realities of its geography. For all its size on paper, many sections of the Confederacy proved inhospitable to maneuver and supply. Union gunboats dominated its coastlines and its great rivers. ${ }^{102}$ Most of Florida was too swampy and too under-populated to provide the South's armies much help. The border states upon which the South counted were either occupied or openly divided between factions sympathetic to both sides. Likewise, when the Union closed the Mississippi it cut the South in half, thereby slicing off a large amount of maneuver room. Mountainous Tennessee, West Virginia, and a large portion of the eastern seaboard's southern states were dominated by the Appalachians and divided between northern and southern sympathizers. In short, the Confederacy lacked a large enough area for guerrilla forces to operate with impunity, especially once Union forces divided and dominated the region after they gained control of the Mississippi. 
Allowing Union troops access to the interior also exposed the Confederate heartland to the ravages of war, something that did not occur until Sherman's March to the Sea in 1864. If Confederate generals fought a defensive war of maneuver, they would have found little territory in which they could safely deploy or resupply. As a result, Confederate generals understood the need to strike quickly and force a decisive encounter outside of southern territory. Disappearing into the southern landscape offered little protection, and posed real dangers for the Confederate armies. The North could have become more aggressive and brought the weight of its military to bear with less difficulty than it did. Fighting a guerrilla campaign also assumes that common Confederate soldiers could fight a war in which they abandoned their homes and families to the enemy. But constantly fighting in southern territory wore on Confederate officers' psyches, leading to frustrations that often manifested themselves in the desire to burn and pillage Union territory. $^{103}$

The following chapters examine the strategies, operations, and tactics of Confederate forces to determine how the South's antebellum honor culture shaped Confederate military operations. Honor, more than any other cultural value, drove their military decisions. Before the war, southern white men lived life according to a rigid honor code that demanded violent retribution for perceived slights. They believed that their personal honor and the honor of their family was deeply tied to the honor of the body politic. The linkage between the southern elite's honor culture and the maintenance of race-based slavery ensured that they perceived assaults on the institution of slavery as an attack on the region's honor. As one northerner observed about slavery's centrality to the southern elite: "All of the people who had obtained any sort of success . . . had owned 
slaves." 104 The growing sectional divide between the North and South in the 1850s reinforced southerners' sense of isolation and defensiveness. With race-based slavery deeply embedded in the society and culture of the South, white southerners conceived the abolitionist movement as a threat to their way of life. A newspaper in New Orleans wrote: "As long as slavery is looked upon by the North with abhorrence; as long as the South is regarded as a mere slave-breeding and slave-driving community; as long as false and pernicious theories are cherished respecting inherent equality ... there can be no satisfactory political union between the two sections."105 The South's decision to go to war in 1861, though certainly not assured, arose from the region's honor-based defense of slavery.

Before the Civil War, antebellum southern aristocrats approached public and private life understanding that their behavior affected their social status. The southern elite indulged in behaviors that reinforced their status as gentlemen or faced social disgrace and ostracism. Confederate officer Thomas R. Cobb summarized the southern aristocrat as someone who must "develop in our own people that highest type of man, which combines physical endurance with cultivated intellect, provident forethought with enlarged benevolence, wise statesmanship with enlightened Christianity . . . To that pristine glory, let us aspire."106 Leadership belonged to the economic, political, and cultural "best men" who embodied the social and cultural values of the southern aristocrat. When the war began, the antebellum southern elite, believing themselves uniquely suited to military service, became the commanders of the Confederate States of America's armies. Prewar militarism and the regular violence that dominated southern life provided them with a distinct advantage as military leaders. As one southerner put it, 
"To such an extent does the military fervor rage, a stranger would conclude at least every other male citizen to be either 'Captain or Colonel, or Knight at arms.' Nor would he greatly err ... for ... he would find more than every other man a military chieftain of some sort or other. ${ }^{, 107}$ Steeped in their plantation culture and trained in the prevailing European military tactics of the day, the southern elite was prepared to fight a cultural war against their northern neighbors. Both sides read the same military literature, considered Napoleon the most influential commander of the previous century, and adapted similar battlefield strategy from their study of Napoleon and Jomini. However, southern honor culture distinguished the two powers from one another and led southern leaders to employ their own culturally based variations on prevailing military theory. Chapters two and three examine the Civil War's battles and campaigns to determine exactly how southern culture changed Confederate behavior on the field of battle.

${ }^{1}$ William Faulkner, The Reivers: A Reminiscence (New York: Random House, 1962), 302.

${ }^{2}$ This characterization of the South was the focus of W. J. Cash's famous work, The Mind of the South. In it, Cash discussed the disconnect between how southerners conceptualized their region and the images associated with it, and how it actually functioned. The idealized South that many southerners imagined differed significantly from the violent, brutal, and race and class obsessed culture that actually existed. ${ }^{3}$ Drew Gilpin Faust, This Republic of Suffering: Death and the American Civil War (New York: Alfred A. Knopf, 2008), 257. In his article "A Census-Based Count of the Civil War Dead," J. David Hacker uses census data to demonstrate the likelihood that the original assumptions of military casualties are lower than the true figures. Faust cites postwar estimates that place Confederate war dead at about two hundred fifty thousand. Using Hacker's research, it is likely that total Confederate casualties, both wounded and dead, were three hundred fifty thousand to over five hundred thousand.

4 "The Civil War, Finally Passing: Assessing America's Bloodiest War, 150 years later," The Economist, March 31, 2011. http://www.economist.com/node/18486035?story_id=18486035 ${ }^{5}$ Culturally based military histories have become more common over the past several decades, as military historians have tried to move away from traditional "tactics and generals" approaches. There is a growing trend to utilize cultural paradigms in conceptual military histories. The most important of these works is John A. Lynn's Battle: A History 
of Combat and Culture from Ancient Greece to Modern America (New York: Basic Books, 2008), which discusses the militaries of specific cultures throughout history, and how cultural assumptions influenced battlefield strategies, tactics, and ideologies. This thesis applies Lynn's reasoning to the Confederate States of America's armies, examining how the antebellum South's honor culture influenced the way its officers fought.

${ }^{6}$ Wyatt-Brown, Southern Honor, 25-27.

${ }^{7}$ Grady McWhiney and Perry D. Jamieson, Attack and Die: Civil War Tactics and the Southern Heritage (Tuscaloosa: University of Alabama Press, 1982), 189.

${ }^{8}$ Wyatt-Brown, Southern Honor, 18-19.

${ }^{9}$ This is especially true of Grady McWhiney's Confederate Crackers and Cavaliers (Abilene: McWhiney Foundation Press, 2002), which compares the last names on southern tombstones with graveyards in England, Scotland, and Ireland. Despite the fact that McWhiney finds a higher connection with Scotland and Ireland than England, he particularly focuses on lower class rather than elite graveyards. Even if McWhiney is correct and the southern elite were more Scot and Irish than English, the southern aristocracy still identified culturally with Royalists.

${ }^{10}$ McWhiney, Confederate Crackers and Cavaliers, 21-23.

${ }^{11}$ Genovese, The Political Economy of Slavery, 246-47.

12 Ibid., 13.

${ }^{13}$ Wyatt-Brown, Southern Honor, 404-407.

${ }^{14}$ Greenberg, Honor and Slavery, 34.

${ }^{15}$ Franklin, The Militant South, 2.

${ }^{16}$ McWhiney, Confederate Crackers and Cavaliers, 22.

${ }^{17}$ Ibid., 23.

${ }^{18}$ McWhiney and Jamieson, Attack and Die, 170.

${ }^{19}$ Wyatt-Brown, Southern Honor, 14-15.

${ }^{20}$ Greenberg, Honor and Slavery, 8.

${ }^{21}$ McWhiney, Confederate Crackers and Cavaliers, 24.

${ }^{22}$ Wyatt-Brown, Southern Honor, 34-35.

${ }^{23}$ U.S. Census Office, Eighth Census [1860], Population of the United States in 1860. (Washington, D.C., 1864).

${ }^{24}$ Wyatt-Brown, Southern Honor, 176.

${ }^{25}$ U.S. Census Office, Eighth Census [1860], Agriculture of the United States in 1860 (Washington, D.C., 1864).

${ }^{26}$ Ibid.

${ }^{27}$ Computing this 3.5 percent number requires an understanding of how Confederate forces were organized, and some basic calculations. At the regiment level, where the authorized strength was one-thousand but the actual strength often numbered less than six-hundred, four to six staff positions - colonel, lieutenant colonel, major, adjunct, and quartermaster - were available. Accounting for floating adjuncts leaves six staff officers at the regimental level. The average brigade had three to six regiments; six officers per regiment times five regiments equals thirty officers to a brigade. A division had two to six brigades; thirty staff officers times five brigades equals six hundred staff officer positions. A corps contains two to four divisions; six hundred staff officers times four divisions equals two thousand four hundred staff positions. The Army of Northern 
Virginia had a wartime average of sixty eight thousand soldiers over its ten principal campaigns, which divided by two thousand four hundred staff positions or about 3.5 percent. Even counting officers attached to a general's staff and not specific regiments, the total percentage of officers per army would not have reached 4 percent. In short, few staff positions were available, restricting command to the southern social elite.

${ }^{28}$ Steven E. Woodworth, ed., Civil War Generals in Defeat (Lawrence: University Press of Kansas, 1999), 2.

${ }^{29}$ In The Last Generation: Young Virginians in Peace, War, and Reunion, Carmichael finds that many of the younger sons of Virginia's elite went to war to prove their manhood and uphold their nation's honor. They often served as junior officers in Confederate forces and represented a disproportionately large part of their army's casualties because of their willingness to prove their courage.

${ }^{30}$ Jason Phillips, Diehard Rebels: The Confederate Culture of Invincibility (Athens: University of Georgia Press, 2007), 79.

${ }^{31}$ Joseph T. Glatthaar, Soldiering in the Army of Northern Virginia: A Statistical Portrait of the Troops Who Served under Robert E. Lee (Chapel Hill: University of North Carolina Press, 2011), 140-42.

32 Ibid., 147.

33 Ibid., 154.

${ }^{34}$ Ibid., 155.

${ }^{35}$ Combined Books, The Civil War Book Of Lists: Over 300 Lists From The Sublime To The Ridiculous (Edison, NJ: Castle Books, 1993), 20-21, 25-26.

36 Ibid., 20, 25.

${ }^{37}$ Lafayette McLaws, A Soldier's General: The Civil War Letters of Major General Lafayette McLaws (Chapel Hill: University of North Carolina Press, 2002), 134.

${ }^{38}$ Glatthaar, Soldiering in the Army of Northern Virginia, 86.

${ }^{39}$ Ibid., 87.

${ }^{40}$ Ibid., 88-91.

${ }^{41}$ Franklin, The Militant South, 2-3.

${ }^{42}$ Wyatt-Brown, Southern Honor, 353-54.

${ }^{43}$ McWhiney and Jamieson, Attack and Die, 186.

${ }^{44}$ Franklin, The Militant South, 175-76.

${ }^{45}$ In Attack and Die, historians McWhiney and Jamieson explore the role of honor among the South's antebellum lower classes, linking Scottish and Scottish-Irish conceptions of violence and honor to the greater southern conceptions of these ideals. They contend that the presence of an honor culture among the South's lower and middle classes, especially in the backwoods populations, corresponded with the elite planter's honor culture, and created a united and violent white society, highly militaristic and battle-ready, despite their social differences.

${ }^{46}$ Fox-Genovese, Within the Plantation Household, 37-38.

${ }^{47}$ Ibid., 100-101.

${ }^{48}$ See Stephanie McCurry, Masters of Small Worlds: Yeoman Households, Gender Relations, \& the Political of the Antebellum South Carolina Low Country for further discussion of gender in the South.

${ }^{49}$ McCurry, Masters of Small Worlds, 284-85. 
${ }^{50}$ McArthur, A Gentleman and an Officer, 162.

${ }^{51}$ Franklin, The Militant South, 25.

52 Ibid., 214.

${ }^{53}$ Wyatt-Brown, Southern Honor, 433-34.

${ }^{54}$ Emory M. Thomas, The Confederate Nation 1861-1865 (New York: Harper Perennial, 1971), 276-77.

${ }^{55}$ Wyatt-Brown, Southern Honor, 370.

${ }^{56}$ Ibid., 35-36.

${ }^{57}$ Wiley Sword, Southern Invincibility: A History of the Confederate Heart (New York: St. Martin's Griffin, 1999), 190.

${ }^{58}$ McWhiney, Confederate Crackers and Cavaliers, 125. McWhiney argues that Confederate forces were predisposed to aggressive action, but his conclusion that this predisposition was linked to ancient Celtic battle practices is less convincing.

${ }^{59}$ Ibid., 126.

${ }^{60}$ Wyatt-Brown, Southern Honor, 28-29.

${ }^{61}$ Franklin, The Militant South, 211-12. "miles Christi” is Latin for Christian soldier.

${ }^{62}$ See Steven E. Woodworth, While God is Marching On: The Religious World of Civil

War Soldiers (Lawrence: University Press of Kansas, 2001).

${ }^{63}$ McWhiney, Confederate Crackers and Cavaliers, 26-27.

${ }^{64}$ Franklin, The Militant South, 17-18.

${ }^{65}$ Wyatt-Brown, Southern Honor, 36, 43.

${ }^{66}$ Ibid., 88-89.

${ }^{67}$ For further reading on European influences on Civil War generals, see Paddy Griffith, Battle Tactics of the Civil War (New Haven: Yale University Press, 2001).

${ }^{68}$ Russell F. Weigley, The American Way of War: A History of United States Military Strategy and Policy (New York: Macmillan Publishing Company, 1973), 82-84.

${ }^{69}$ Russell F Weigley, Age of Battles: The Quest for Decisive Warfare from Breitenfeld to Waterloo (Bloomington: Indiana University Press, 1991), xiii-xiv.

${ }^{70}$ Ibid., 542.

71 Ibid., xii.

${ }^{72}$ Lynn, Battle, 132.

${ }^{73}$ Weigley, The American Way of War, 78.

${ }^{74}$ Ibid., 79.

${ }^{75}$ Lynn, Battle, 193.

${ }^{76}$ Weigley, The American Way of War, 82-83.

${ }^{77}$ Lynn, Battle, 196-97.

${ }^{78}$ For further reading on the European military context see Jeremy Black, Western Warfare 1775-1882 (Bloomington: Indiana University Press, 2001); Christopher Duffy, Military Experience in the Age of Reason 1715-1789 (New York: Barnes \& Noble Books Inc., 1987); Azar Gat, A History of Military Thought: from the Enlightenment to the Cold War (New York: Oxford University Press, 2001); David Gates, Warfare in the Nineteenth Century (New York: Palgrave, 2001); Gunther E. Rothenberg, The Art of Warfare in the Age of Napoleon (Bloomington: Indiana University Press, 1978); and Hew Strachan, European Armies and the Conduct of War (New York: Routledge, 2004).

${ }^{79}$ Weigley, The Age of Battles, 538. 
${ }^{80}$ At the Battle of Leipzig in 1813, Napoleon and his opponents hammered one another with nearly six hundred fifty thousand soldiers across the battlefield for three days, resulting in nearly one hundred twelve thousand casualties. By the end of the War of 1812, the American army did not exceed forty thousand soldiers.

${ }^{81}$ Weigley, The American Way of War, 54-55.

82 Ibid., 67.

${ }^{83}$ Andrew, Long Gray Lines, 10-11.

${ }^{84}$ McWhiney, Confederate Crackers and Cavaliers, 79-80.

${ }^{85}$ Andrew, Long Gray Lines, 1. Several major southern schools chartered or reorganized along military lines during this period, including the Virginia Military Institute (1839),

The Military College of South Carolina, better known as The Citadel (1842), the

Kentucky Military Institute (1845), the Georgia Military Institute (1851), and the Bastrop Military Institute (1857).

${ }^{86}$ Andrew, Long Gray Lines, 13.

${ }^{87}$ For example, the Georgia Military Institute (1851), and the Bastrop Military Institute in Texas (1857).

${ }^{88}$ For further reading on Jomini's influence on American commanders during the Civil War, see Carol Reardon, With a Sword in One Hand \& Jomini in the Other: the Problem of Military Thought in the Civil War North (Chapel Hill: University of North Carolina Press, 2012); and Wayne Wei-saing Hsieh, West Pointers and the Civil War (Chapel Hill: University of North Carolina Press, 2009).

${ }^{89}$ McWhiney, Confederate Crackers and Cavaliers, 115-16.

${ }^{90}$ McWhiney and Jamieson, Attack and Die, 14.

${ }^{91}$ Anne Sarah Rubin, A Shattered Nation: The Rise and Fall of the Confederacy, 1861 1868 (Chapel Hill: University of North Carolina Press, 2005), 115-16. See also, Bradley Clampitt, The Confederate Heartland: Military and Civilian Morale in the Western Confederacy (Baton Rouge: Louisiana State University Press, 2011).

${ }^{92}$ McWhiney and Jamieson, Attack and Die, xv.

${ }^{93}$ See Alan T. Nolan, Lee Considered: General Robert E. Lee and Civil War History (Chapel Hill: University of North Carolina Press, 1991); and Russell Weigley, The American Way of War.

${ }^{94}$ Robert G. Tanner, Retreat to Victory: Confederate Strategy Reconsidered (Wilmington, DE: Scholarly Resources Inc., 2001), xi-xii.

${ }^{95}$ Nolan, Lee Considered, 70-71.

${ }^{96}$ See James M. McPherson, Tried By War: Abraham Lincoln as Commander-In-Chief (New York: Penguin Press, 2008).

${ }^{97}$ McLaws, A Soldier's General, 142.

${ }^{98}$ Gary W. Gallagher, The Confederate War: How Popular Will, Nationalism, and Military Strategy Could Not Stave Off Defeat (Cambridge, MA: Harvard University Press, 1997).

${ }^{99}$ Wyatt-Brown, Southern Honor, 145.

100 Tanner, Retreat to Victory, xvi-xvii. See also Alan Nolan, Lee Considered; and Joseph L. Harsh, Confederate Tide Rising: Robert E. Lee and the Making of Southern Strategy, 1861-1862 (Kent, OH: Kent State University Press, 1998). 
${ }^{101}$ Peter S. Carmichael, ed., Audacity Personified: The Generalship of Robert E. Lee (Baton Rouge: Louisiana State University Press, 2004), 23.

${ }^{102}$ For further reading on the role of Union and Confederate naval forces during the Civil War, see Spencer C. Tucker, Blue and Gray Navies: The Civil War Afloat (Annapolis: Naval Institute Press, 2006); and Jay W. Simson, Naval Strategies of the Civil War: Confederate Innovations and Federal Opportunism (Nashville: Cumberland House, 2001).

${ }^{103}$ Braxton Bragg's pronouncement before his invasion of Kentucky reflected such attitudes: "The enemy is before us, devastating our fair country, imprisoning our old and venerated men (even ministers of God), insulting our women, and desecrating our altars. It is our proud lot to be assigned the duty of punishing and driving forth these deluded men, led by desperate adventurers and goaded on by Abolition demagogues and demons. Let us but deserve success and an offended Deity will certainly assure it. Should we be opposed, we must fight at any odds and conquer at any sacrifice. Should the foe retire, we must follow him rapidly to his own territory and make him taste the bitters of invasion." Shelby Foote, The Civil War, a Narrative: Fort Sumter to Perryville (New York: Vintage Books, 1986), 584.

${ }^{104}$ Karen E. Fritz, Voices in the Storm: Confederate Rhetoric, 1861-1865 (Denton: University of North Texas Press, 1999), 79.

${ }^{105}$ Ibid., 80.

${ }^{106}$ Ibid., 103-104.

${ }^{107}$ McWhiney and Jamieson, Attack and Die, 171. 


\section{CHAPTER 2: COURAGE, CONFIDENCE, AND CAVALIERISM: THE CIVIL WAR FROM FORT SUMTER TO GETTYSBURG AND VICKSBURG}

On the morning of July 3,1863 , after two days of desperate fighting among the rocks, hills, orchards, and wheat fields surrounding the small Pennsylvania town of Gettysburg, armies of the United States and the Confederate States of America eyed each other warily. Despite a series of attacks that resulted in thousands of casualties, the Confederate Army of Northern Virginia had been unable to dislodge the Army of the Potomac from its strong defenses on the outskirts of town. However, the Confederates, led by their commander, Robert E. Lee, retained the battle's tactical initiative and determined to continue the assaults. At two o'clock in the afternoon, Lee launched twelve thousand five hundred of his infantry directly against the center of the Union line. Buttressed by strong artillery emplacements, prepared firing positions, and a commanding view of the fields through which the Confederate units had to advance, the Union forces repulsed the doomed Confederate attack. The commander of an Alabamian regiment at the center of the attack observed: "My men . . . advanced about half way to the enemy's position, but the fire was so destructive that my line wavered like a man trying to walk against a strong wind, and then slowly, doggedly, gave back .... My dead and wounded were then nearly as great in number as those still on duty. They literally covered the ground. The blood stood in puddles in some places . . the ground was soaked with the blood of as brave men as ever fell on the red field of battle." ${ }^{1}$ More than 50 percent of the Confederate infantry who set out in the afternoon heat of that famous July day were killed, wounded, or captured within an hour. ${ }^{2}$ The Confederate attack 
failed, and with it the Confederacy's chances for a decisive victory in Union territory. In 1948, William Faulkner summed up the South's hope, confidence, and easy selfassurance, soon to be broken by defeat, when he described a postwar southern boy imagining the battle just before 2pm on July 3, 1863: "This time. Maybe this time with all this much to lose than all this much to gain: Pennsylvania, Maryland, the world, the golden dome of Washington itself to crown with desperate and unbelievable victory the desperate gamble, the cast made two years ago."

The decision by Lee and his staff to attack the well-entrenched and prepared Union lines on the third day of the Battle of Gettysburg remains one of the most controversial assaults of the war. Pickett's Charge, as the attack became known, illuminates how the southern military leadership viewed battlefield confrontation. Confederate leaders often ignored military realities, believing that the fighting capabilities of their men could overcome deficiencies like those at Gettysburg. Pickett's Charge resulted from faulty cultural assumptions, not rational military thought. Few of Lee's generals had qualms about the assault, and after the decision to attack was made only General James Longstreet continued to object. ${ }^{4}$ Despite understanding the extreme loss of life the attack would almost certainly cost, why then did the Confederate leadership willingly and confidently order it? This decision demonstrates how the South's prewar culture became the guiding spirit for wartime military decisions. Lee and his command staff believed that Confederate forces could overcome any obstacle because their soldiers were better, their way of life superior, and their cause more just. As Major General Lafayette McLaws, one of Lee's divisional commanders, observed of the northern populace three days before the battle: "[northerners] are a very different race 
from the southern. There is a coarseness in their manners and looks and a twang in their voices - which grates harshly on the senses of our men [;] the distinction of class, the poor \& sick is very marked." Sandie Pendleton, one of Lee's staff officers agreed: "[we must] dictate to the [local] inhabitants as masters. I do believe in it [southern superiority] now more than ever before. There is an innate difference between Yankee and a Southerner. I have ever believed, but the exalted superiority of one race has never struck me so forcibly." McLaws and the Confederate leadership believed in the superiority of their men over the weak northern enemy. In this context, Confederate commanders had little reason to fear attacks like Pickett's Charge would fail, because their men were simply superior to their enemy.

Chapter two examines the Civil War's battles and campaigns between 1861 and 1863, from Fort Sumter to Gettysburg and Vicksburg, to show how southern cultural beliefs influenced Confederate military decisions. The prewar elite believed that their personal honor and the honor of their households played vitally important roles in the way their community perceived them. Southern cultural paradigms demanded that men defend their honor and the honor of their women. When discourse in the South focused on national issues, especially slavery and state's rights, southerners attached their personal code of honor to the body politic. Northern rhetorical attacks on the South required the same satisfaction that disagreements between gentlemen demanded. The southern honor culture predicated the maintenance of honor on aggressive and violent forms of display, reinforced by the violent nature of antebellum life. The violence and brutality of slavery, slave patrols, militia service, dueling, hunting, and brawling all hardened the southern elite to violent activities. When war broke out after decades of 
animosity between the North and South, the southern aristocracy suddenly had the opportunity to exact violent retribution in a context eminently familiar to them. Focusing on how Confederate officers conceptualized the war, their enemy, their prospects for success, and their own involvement in military operations, this chapter explains why southerners believed they would win easily, why they believed their culture made them better soldiers, and how they relied on aggression to deliver victory. The first encounter between the emergent Confederate military and the Union occurred at Fort Sumter, which precipitated full-scale armed conflict between the two powers.

Twenty-nine years before Confederate shore batteries opened fire on the federal garrison in Charleston harbor, South Carolina stood at the center of another national crisis. In 1832, the state convention of South Carolina declared the contentious tariffs of 1828 and 1832 unconstitutional and refused to enforce them in the state. ${ }^{7}$ Declaring their right to nullify federal laws that did not benefit them, South Carolina prepared to back their rhetoric with military force. President Andrew Jackson worried that an "attempt will be made to surprise the Forts and garrisons by the militia." Such an attack, Jackson stated, "must be guarded against with vestal vigilance and any attempt by force repelled with prompt and exemplary punishment." ${ }^{\prime 8}$ Despite violent rhetoric on both sides, compromises in Congress lowered the national tariffs to palatable numbers for the South. Believing the lower tariffs constituted a victory for their state and region, South Carolina proudly remembered its role as the sole aggressor against the federal government. In December 1860, South Carolina was the first state to secede from the Union, followed by ten more states within five months. ${ }^{9}$ 
The Nullification Crisis of 1832 demonstrated several things to southern fireeaters who anticipated further conflict with the federal government. Most important, they recognized the need to seize federal batteries, forts, and arsenals before they could become flash-points of national contention. As the southern states seceded, they seized federal installations, often relying on southern sympathizers in the federal forces to surrender their forts peacefully. ${ }^{10}$ This process continued with little drama, until only two major forts remained in Union hands in the South, Fort Sumter in Charleston Harbor and Fort Pickens in Florida. ${ }^{11}$ In April 1861, the Confederates decided to bombard Fort Sumter and precipitate an armed conflict to secure Confederate independence. The South's prewar cultural paradigms help explain why Confederate forces fired on Fort Sumter instead of starving the garrison into submission. Despite all of the risks associated with acting as the belligerent party, southerners, guided by confrontation-based behaviors, chose to strike first. The Confederate officer class believed negotiation useless and war the only recourse. Griffin wrote, "There is a good deal of talk of peace movements but I don't believe a word of it. Our only chance for peace lyes in our rifles, that will bring it after awhile, if we will only remain true to ourselves." 12

In early March, Brigadier General P. G. T. Beauregard took command of all Confederate military forces surrounding the beleaguered Union forces at Fort Sumter. Well aware of the garrison's dwindling supplies and close friends with its commander, Major Robert Anderson, Beauregard initially remained content to starve the fort into submission if federal forces did not try to interfere. ${ }^{13}$ But failed Union attempts to resupply the position by sea heightened tensions. Despite the likely victory patience would produce, Confederate forces opened fire on April 12, pummeling the fort into 
submission. ${ }^{14}$ The Confederate government ordered the bombardment of the fort, despite knowing that they would appear as the aggressive party, because of the military's immersion in the South's antebellum culture. Prewar conceptions of honor, masculinity, duty, and courage demanded that the southern gentlemen who led Confederate armies maintain the trappings of the aristocracy while on campaign. They intrinsically linked the honor of the individual to the honor of the Confederate states, and insults to the states prompted the same response as personal insults between gentlemen. The same cultural imperative drove many Confederate decisions during the war.

The intrusive presence of Fort Sumter represented an insult to the military power of the seceded states. ${ }^{15}$ Its presence in the harbor of the Confederacy's most belligerent state guaranteed heightened tensions. Abraham Lincoln's repeated attempts to resupply and reinforce the garrison further insulted southerners who believed the federal properties in the South should revert to their control when they seceded. Southerners perceived attempts by the northern government to reinforce these installations as interference with their internal affairs. Even with the Confederate government in its infancy, southern culture helped fill the vacuum of decision-making, enabling state and local leaders to coordinate military actions while the Confederate government was initially located in Montgomery, Alabama. Despite few formal orders from the Confederate government, state leaders used their militia to seize federal installations and turn them over to the new government. At Fort Sumter, the state militias blended with newly appointed Confederate military commanders to seize the garrison. When Jefferson Davis and his cabinet authorized Beauregard to open fire they did not respond to an immediate military incentive. Instead, wounded honor, an effort to drag undecided state legislatures into 
secession, and a collective interest in demonstrating the strength of the southern states led them to war. ${ }^{16}$ In keeping with this gentlemanly behavior, Beauregard notified his friend Major Anderson when the first shots would come, so the federal officer could prepare himself and his garrison. ${ }^{17}$

After the fall of Fort Sumter and Lincoln's call for seventy-five thousand soldiers to crush the rebellion, four more southern states joined the Confederacy. ${ }^{18}$ The bombardment of Fort Sumter and the demands of the Union government made it impossible for southern states like Virginia, Tennessee, Arkansas, and North Carolina to remain neutral. Before the commencement of hostilities, these states hoped that war could be avoided through negotiation. But they viewed Lincoln's letter demanding they send soldiers to put down their fellow southern states as an insult that their collective honor would not allow. ${ }^{19}$ They decided to secede when Congress demanded they attack states whose culture, politics, and goals reflected their own.

The political, social, and economic leaders of the antebellum South dominated the Confederacy's military leadership. When war broke out, these men entered military service because their place in southern society demanded it. As they transitioned from planters, judges, statesmen, and other peacetime occupations to military command, they brought their unique cultural outlook with them. Many had prior military experience or attended military schools during their youth, reinforcing the fusion of southern culture and military service. Of the original fourteen Confederate military departments, all were commanded by men who had either prewar military service or schooling, and all were either born into the planter class or joined it by marriage. ${ }^{20}$ Of the 425 men who achieved the rank of general in the Confederate military, 69 percent had prewar military 
experience. ${ }^{21}$ The antebellum southern elite entered the war well versed in the military theory of the day, and buttressed this knowledge with their unique cultural paradigms. These men valued honor, courage, and aggression, believing that cowardice and retreat stained the dignity of a man. One officer presented his new regiment a flag to bear in battle that read simply, "No Retreat." 22

However, these men infrequently expressed their cultural instincts overtly. Instead, the ways southern culture shaped their military decision making reveals itself in two ways. First, Confederate commanders' campaign and battlefield decisions often reflected their cultural imperatives. Aggressive attacks, stubbornly refusing to alter their decisions, refusing to withdraw despite disadvantage, and fruitless but gallant assaults offered ways for them to demonstrate honor and bravery to their fellow officers. In addition, many commanders made strategic decisions based on perceived honorable actions such as protecting civilian populations, defending southern territorial integrity, and flashy displays of military prowess, such as General J. E. B. Stuart's 1862 and 1863 cavalry rides around the Union Army. Collectively, these actions demonstrate a military deeply influenced by the ideal of the dashing and courageous cavalier. Living up to the standards of this paragon of southern virtue proved a powerful motivator for the Confederacy's officer corps.

Second, the written record of the Confederate officer corps offers insight into their motivations. Officers in command positions had the ability and position to influence battlefield encounters. These men were literate and sought to highlight their service record after the war. In fact, more than 80 percent of all Confederate soldiers were literate. ${ }^{23}$ Their writing survives in several mediums: personal letters written to wives, 
family members, and friends at home; official military correspondence; and detailed war memoirs written and published after the war's conclusion. In their detailed campaign memoirs and military correspondences, officers often directly commented on the impetus behind their wartime decisions. In their letters home, officers rarely dwelled on the specifics of military management. However, these letters often discussed personal motivations about why they fought, what the Confederacy meant to them, and the ideals embodied in southern honor culture. In short, the primary record the Confederate officer class left behind provides a window to their motivations, beliefs, and actions.

$* * *$

After the fall of Fort Sumter both sides dramatically increased the size of their armed forces and the Confederate states worked feverishly to construct a regular army from a limited prewar infrastructure. The loose nature of the Confederate government, in which states held disproportionate power, made it difficult to create and sustain a unified army. On March 6, 1861, the Confederate Congress created a regular Confederate Army to operate alongside a Provisional Army, which would disband at the successful completion of the war. ${ }^{24}$ However, individual state governors and legislatures resisted giving control of their armed forces to the national government, and instead formed militia regiments based on state-wide recruiting. Only after the Confederate Congress created the Confederate War Department February 26, 1861 did it gain control over recruiting and the direction of the war effort. Chronically short of soldiers, the Confederate Congress passed a conscription act in early 1862 to guarantee a steady 
stream of soldiers to the field armies instead of state militia units, further tying the Confederate military to the national government. ${ }^{25}$

Though a numerical military inequality between the Union and the Confederacy existed throughout the Civil War, the South made an enormous cultural investment in the conflict. The eleven states that comprised the Confederacy had a military age (18-45) white population of $1,064,193$ in 1861 , while the United States had some 4,559,872 potential soldiers. ${ }^{26}$ The Confederacy was at a disadvantage because of this disparity, but it also enjoyed a series of alleviating circumstances. Total Confederate enlistments for the four-year war period amounted to 1,082,119, higher than their entire white male population of military age in $1861 .^{27}$ This number includes a significant number of reenlistments and enlistments of individuals outside military age, revealing the powerful cultural impetus to serve. Furthermore, with a population dependent on slaves to produce food for the army, fewer men needed to stay at home, freeing a higher percentage of men for the army than in the North. The extremely high enlistment numbers also reflect multiple enlistments of three types: men who intentionally enlisted, deserted, and then reenlisted under a different name to gain the enlistment bounty; men who reenlisted after discharge or injury; and men who reenlisted after their terms of service ended. Even if reenlistment does not explain the high enlistment numbers, many historians argue that a minimum of six hundred thousand southerners served in the regular armies during the war, with about four hundred thousand active at any one time. ${ }^{28}$ A southerner explained the impetus to serve:

[Soldiers] defend the last refuge of civil liberty against the atrocious aggressions of a remorseless tyranny. I honor [them] for it; the world honors [them] . . and there will be inscribed upon [their] monument the highest tribute ever paid to a man. He has stood bravely in the breach, and interposed the unspotted arm of 
justice between the rights of the South and the malignant usurpation of power by the North. ${ }^{29}$

Ironically, this society-wide military fervor benefited only an elite few. In a war fought to defend slavery, the vast majority of enlisted men were poor, non-slave owning whites. The officer class, who stood to lose a great deal if defeated, did a tremendous job keeping their poor citizens in the ranks and keeping them motivated using the honor-based codes with which they had grown up. As slaveholder Major General John B. Gordon wrote after the war, "Slavery was undoubtably the immediate formenting cause of the woful [sic] American conflict." ${ }^{30}$

Despite the aggressive announcement of Confederate military intentions at Fort Sumter in April 1861, Confederate forces did not follow up their victory with immediate offensive operations. This lack of activity occurred for several reasons, many practical and some cultural. Most practically, in spring 1861 the Confederate military remained a jumbled organization lacking in direction, supply, management, and combat experience among its enlisted men. However, the deficiencies of the Confederate war effort and strategic decision-making could be overcome through its culture. Where strong governmental communication and direction failed, a largely unified southern culture filled the void, allowing for consistent behavior in the face of bureaucratic confusion. In the wake of the successful bombardment of Fort Sumter, no Confederate units violated the territorial integrity of the United States in the East or West. From early June to late July, culminating at the Battle of Bull Run, Union units repeatedly invaded and skirmished with Confederate forces in southern territory. Confederate General William H. T. Walker despaired that the early skirmishing would ever evolve into the glorious battle he and his fellow aristocratic officers craved: "this sitting down and waiting to be 
whipped ... is to me the most disgusting. If it be my fate to lose my life in the cause ... in Heavens name let me die like a soldier with sword in hand boldly leading my men on a fair and open field." ${ }^{31}$ Griffin echoed Walker's comments: "I am getting awfully tired of this defensive [posture] .... [The] soldiers grow extremely eager for a fight ... I believe they would, almost to a man, be delighted if the Enemy would come along ... [we] will now be able to give the Yanks a warm welcome." ${ }^{32}$

The decision of Confederate leaders not to enter northern territory at the war's outset also reflected the imperatives of the South's prewar honor culture. By starting the war at Fort Sumter, Confederate forces had delivered a metaphorical glove-slap to the North. With honor momentarily satisfied by the issue of a challenge to arms, Confederate leaders then waited for the North to accept the next part of the ritualistic formula. Invading northern territory after starting the war would have violated the southern honor culture. Whether Union commanders understood their reciprocal actions in this context was immaterial. For southerners, the North's repeated violations of Confederate territory in northern Virginia served as an acceptance of the high stakes duel upon which the two powers were about to embark. As Nat Dawson, an officer from Alabama explained, the "[Union] invasion has stirred my blood and I think it will be a pleasure to meet our enemies in mortal combat. We will now have a bloody war, and we intend to make it as destructive as possible." ${ }^{33}$ Henry Ravenel, a plantation owner from South Carolina, expounded upon this idea:

I fear the northern people have an impression that we are unable to cope with them, from inferiority in numbers, want of necessary means, and that our slave population is an element of weakness. It may be necessary therefore that they should be disabused of such impression. If we must pass through this terrible ordeal of war to teach them this lesson, so be it. It may be best in the end. We put our trust in the God of battles. ${ }^{34}$ 
According to the South's honor code, once the war had commenced on equal terms Confederate forces could commence aggressive military operations, with an army under Major General Leonidas Polk violating the state of Kentucky's neutrality in September $1861 . .^{35}$

The first major battle of the war occurred at Bull Run on July 21, 1861, where despite amateurish maneuvering, Confederate forces claimed victory. P. G. T. Beauregard, commanding the Confederate forces, encamped at the important Manassas Junction, a collection of railroad hubs from which both armies could procure supplies and reinforcements. His Union opponent, Irvin McDowell, advanced from Washington with explicit orders to defeat any Confederate forces he met and end the rebellion quickly. Believing victory over the Confederacy would require no more than an afternoon, rich northern spectators came to the battlefield with picnic baskets to watch the spectacle. ${ }^{36}$ For Beauregard, simply avoiding a major defeat would solidify the Confederacy's military legitimacy and its strategic position. Accomplishing this required a conservative campaign plan, which would also not tax his poorly developed system of supply. In addition, Beauregard's forces, though highly motivated, were poorly trained, and his subordinates had not yet adjusted to commanding large units for the first time. As Lincoln told McDowell, "You are green, it is true, but they are green also. You are all green alike." ${ }^{37}$ Even many officers with previous command experience had not seen service since the Mexican-American War, more than a decade before. Confederate General Thomas Jackson, soon to gain fame at the Bull Run, shared how he believed green southern troops should be instructed, saying they must be taught to "close with the enemy and destroy him.. ${ }^{38}$ As southern commanders prepared for battlefield conflict, 
they relied on their cultural aggression to guide them through their army's inexperience and inefficiencies.

Despite these factors and the benefits of fighting defensively, Beauregard and his subordinates decided to launch an attack on the Union left flank, in conjunction with Confederate forces marching from the Shenandoah Valley under General Joseph Johnston. McLaws noted that the army and its commanders favored initiating the battle: "It is the ardent desire of our men to get at the enemy. It seems as if they all wish to let off their pent up vengeance, which has been collecting for years past." ${ }^{39}$ According to another of Beauregard's subordinates, General Jubal Early, aggressive action was the only plan that Beauregard and Johnston ever considered:

[General Beauregard] stated that he had no doubt Johnston's attack would be a surprise to the enemy, that the latter would not know what to think of it, and when he turned to meet that attack and found himself assailed on the other side, he would be still more surprised and would not know what to do, that the effect would be a complete rout, a perfect Waterloo, and that we would pursue, cross the Potomac and arouse Maryland. ${ }^{40}$

Unbeknownst to the Confederate staff, McDowell also planned an attack on the Confederate left flank, which meant both armies attacked one another on opposite ends of the battlefield. ${ }^{41}$ The Union attack was larger, better coordinated, and consequently threatened to disrupt and rout the entire Confederate left. Several Confederate regiments broke under the strain, but a Virginian brigade commander, Thomas Jackson, distinguished himself and his men by holding the wavering Confederate battle line. Timely Confederate reinforcements under Johnston arrived on the battlefield by train, overrunning several Union artillery positions, and breaking the impetus of the Union advance. Union forces began an orderly withdrawal, but rumors of Confederate cavalry panicked the retreating columns, and the roads to Washington were soon packed with 
fleeing soldiers and civilian spectators. ${ }^{42}$ Despite the rumors, the Confederate army was in equal disarray because of their victory and unable to pursue. A poorly planned and disastrously implemented attack by Beauregard led to victory, mainly because of Johnston's timing and Jackson's conduct. Still, the First Battle of Bull Run demonstrated the importance of aggression to Confederate commanders. Despite significant incentives to fight defensively, including a poorly trained army, hope of reinforcement, and the knowledge that only a serious defeat would crush the rebellion, Beauregard still decided to attack. Like most Confederate commanders, he ignored sound military reasoning in pursuit of aggressive action. Without the timely arrival of Johnston or Jackson's stand, the Confederates would likely have lost the battle. ${ }^{43}$

Jackson soon became one of the most important representatives of the South's aristocratic generals. Loyal, aggressive to the point of rashness, and deeply Christian, Jackson exemplified the notion of Christian gentility among the southern military gentry. Gordon described Jackson's aggression glowingly: "he would formulate that judgment [to attack], risk his last man upon its correctness, and deliver a stunning blow, while others less gifted were hesitating and debating as to its wisdom and safety."44 His later commander and the man who eclipsed him in the Confederate pantheon, Robert E. Lee, started the war poorly as a combat commander, defeated in a minor campaign in western Virginia. His tentative tactics earned him the nickname "Granny Lee" in the press, and the army reassigned him to supervise the construction of fortresses in North Carolina. ${ }^{45}$ Lee's reassignment served as a tacit acknowledgment of the Confederate government's bias against commanders who appeared unaggressive or hesitant. Though Lee later 
reemerged as the Confederacy's greatest commander, many southern officers and civilians were deeply unimpressed with his first campaigns.

In the West, Confederate strategists focused on the vitally important state of Kentucky, which a pro-Union legislature controlled, despite its southern-sympathizing governor. ${ }^{46}$ Unlike the divided Union commands in the West, Albert Sidney Johnston guided Confederate operations, and though outnumbered he determined to take the war to the North. Union General Ulysses S. Grant's successful sieges at Forts Henry and Donelson revealed the Confederate weakness in the West. ${ }^{47}$ Union control of river forts meant that aggressive Confederate operations exposed the southern heartland to Union penetration. But these considerations ultimately did not derail the aggressive strategic formulations of southern generals who believed that offensive operations could bring military victory. To that end, Johnston and the newly transferred Beauregard contrived to destroy Grant's army in a single battle.

By early April 1862, Grant's forces had advanced all the way into southwestern Tennessee, using its control of the Tennessee River to supply and shield itself from Confederate forces. On the night of April 5, Grant dispersed his scattered army over a wide area, incorrectly believing Confederate forces were not in the vicinity ${ }^{48}$ However, Johnston and Beauregard managed to encamp just two miles from Union lines without detection. Beauregard hesitated to attack, believing that Union pickets must have heard the Confederate army marching and firing their guns to test their powder in the rainy dampness, meaning they had lost the element of surprise. ${ }^{49}$ Epitomizing the southern understanding of battle, Johnston told Beauregard that he would "attack them if they were a million. ${ }^{, 50} \mathrm{He}$ drew directly on his southern sense of honor and masculinity when he 
told his troops, "I have put you in motion to offer battle to the invaders of your country. Remember the dependence of your mothers, your wives, your sisters, and your children on the result. Remember the fair, broad, abounding land, the happy homes, and the ties that would be desolated by your defeat." ${ }^{51}$ Johnston's circular to his troops clearly tied battle to southern conceptions of home and hearth, insinuating that defeat would bring ruin to what his soldiers valued most. Military officers repeatedly tried to motivate soldiers before battle, but Johnston's circular reveals how Confederate leaders linked aggression and bravery to the preservation of the southern homeland and everyone in it.

The ensuing Battle of Shiloh closely resembled the Battle of Marengo in 1800, during which Napoleon was caught and nearly defeated because he carelessly scattered his army for the night in the face of large Austrian forces. ${ }^{52}$ Like Napoleon, Grant believed his adversary unable to attack, but on the morning of April 6, Confederate forces crashed through Union picket lines and roared into sleepy Union camps. ${ }^{53}$ Grant, several miles downstream at the time of the attack, was caught by surprise. Despite severe losses and the collapse of several brigades, one of Grant's subordinates, William T. Sherman, managed to rally the army long enough for reinforcements to arrive. Johnston was killed in the confused melee at the "Hornet's Nest," a Union strongpoint that Confederate commanders refused to bypass on their way through the broken Union lines. ${ }^{54}$ Beauregard witnessed Brigadier General John C. Breckinridge lead an attack against the salient:

General Johnston was astonished at the resolute resistance encountered there. After causing General Breckinridge to appeal to the soldiers, and after doing so himself, he ordered a charge, which he led, in person, with his well-known valor, and during which he was wounded in the leg, without first realizing the extent of his injury. ${ }^{55}$ 
Confederate forces launched as many as twelve separate assaults into this salient, rather than going around it. ${ }^{56}$ Again, Confederate officers subjugated military reason to a stubborn willingness to engage the enemy. Despite the losses incurred and Johnston's death, the first day's fighting represented a rousing success for the Confederates. Their actions over the next several days, however, set a deadly precedent for southern tactical aggression and severely damaged their army. After the first day, Grant tightened his defenses and prepared to fight again, this time from much stronger positions and with additional reinforcements. Beauregard planned to attack again, but was surprised to wake in the morning to an overwhelming Union attack on his line. Instead of trying to hold on, Beauregard launched several counterattacks that severely weakened the fighting capabilities of his army. ${ }^{57}$

Shiloh foreshadowed many battles the Confederates nearly won. ${ }^{58}$ After early success, Confederate leaders refused to break off the engagement when it had become apparent that further attacks would not bring victory. Southern leaders' distaste for cowardice, a product of their honor culture, led them to make tactical discretion subservient to sustained aggression. Shiloh established a pattern of early tactical success, followed by futile bloodletting that Confederate officers followed at the Seven Days Battles, Stones River, Second Corinth, Antietam, Chickamauga, Gettysburg, and the Wilderness. These battles highlight the deadliness of the southern style of warfare. Notions of honor and masculine bravery, rather than tactical concerns, motivated southern battlefield maneuvers. Beauregard lamented the stubborn willingness of Confederate officers to expose themselves to fire that cost Johnston his life:

It is but true to state here, that never from the opening of the battle up to the hour of his death, had General Johnston occupied on the field the position which was 
properly his own, as Commander-in-Chief of our forces. From the place he had himself selected on our line, and where he remained to the last, he was but acting the part of a [lower officer], and as such . . exposing his person [to fire]. ${ }^{59}$

Even when retreat became necessary or advantageous, staff level Confederate officers hesitated to break contact. Confederates forces at Shiloh accomplished most of their objectives on the first day and the tactical situation did not call for further attacks, especially after Johnston's death, but they did not withdraw or end their counterattacks against Union forces that clearly outnumbered their own. Stubbornness, protection of honor, and fears of being labeled a coward proved a costly pattern for the Confederate military. Major General Braxton Bragg described what he learned at Shiloh: "a valuable lesson, by which we should profit — never on a battlefield to lose a moment's time . . . press on with every available man, giving a panic-stricken and retreating foe no time to rally, and reaping all the benefits of success never complete until every enemy is killed, wounded, or captured." 60

A month before Shiloh, Stonewall Jackson set out from Richmond on one of the most successful Confederate campaigns of the entire war, seeking to prevent the reinforcement of the Army of the Potomac as it marched on the Confederate capital under General George McClellan. ${ }^{61}$ Jackson moved up and down the Shenandoah Valley, home to rich farmlands, pinning down Union divisions much needed by McClellan. In a war characterized by Confederate numerical deficiency, Jackson's Valley Campaign stands as one of the South's most lopsided successes. Jackson waged a campaign of maneuver, 
preserving his forces in the face of significant Union pursuers. For more than a month Jackson moved through the Valley surprising and destroying isolated Union detachments without ever enjoying numerical parity. The success of the Valley Campaign became a symbol to the Confederate public of the possibility of offensive action. Though tasked with holding down the Union forces in the vicinity, Jackson managed to kill, capture, and drive back more than sixty thousand Union soldiers, never having more than seventeen thousand men himself. ${ }^{62}$ If Jackson's performance at Bull Run had not already thrust him into the national spotlight, the Valley Campaign guaranteed his celebrity. Moreover, it proved for southern officers the viability of outnumbered offensive action, especially through operational aggression. Other Confederate commanders attempted to duplicate Jackson's tactics, often by dividing their forces in the face of greater Union numbers, but they could not replicate his success. Jackson's Shenandoah campaign helped cement his legend because it represented all that a southern gentleman of the best qualities could achieve. McLaws was particularly impressed: "The news that comes to us of the successive victories gained by Jackson over our enemies has over and over again electrified us and inspired new hope for our cause. ${ }^{, 33}$ Though outnumbered significantly, Jackson's force defeated Union armies many times its size, rallied the morale of the civilian population of the Shenandoah Valley, and reinforced the ideal of the cavalier fighting for hearth and home. As a soldier and a gentleman, Jackson became the darling of the southern populace, the Confederacy's most visible officer. ${ }^{64}$

The success of the Valley Campaign played a significant role in the subsequent Union campaigns against Richmond. Union General George B. McClellan was a talented organizer but tentative combat commander. ${ }^{65}$ After the Union mistakes at First Bull Run 
he determined to build and sustain an army capable of overrunning the outnumbered and undersupplied Confederate forces marshaled under the command of Confederate General Joseph E. Johnston. But McClellan's timid leadership and his exaggeration of the size of Confederate forces delayed his planned invasion of Virginia by three months. Despite his own misgivings, McClellan's overwhelming strength at the beginning of the Peninsular Campaign (nearly one hundred twenty thousand men compared to Johnston's seventy thousand) threatened to steamroll the Confederate forces in northern Virginia. ${ }^{66}$ McClellan's march toward Richmond gained an air of inexorability, with Johnston unable to engage him favorably or slow his progress. Sensing that he could not survive a siege en forme, Johnston decided to attack the Union Army to slow its advance and drive McClellan away from Richmond.

As a student at West Point, Johnston demonstrated an aptitude for combat command, and during the Mexican-American War he repeatedly led important assaults, resulting in multiple promotions as well as multiple wounds. ${ }^{67}$ Johnston's long experience in the United States military made him one of the most important commanders in the South's armies. He wrote to Lee and Davis to explain his campaign plans, "We must ... take the offensive, collect all the troops we have in the East and cross the Potomac with them, while Beauregard, with all we have in the West, invades Ohio. Our troops have always wished for the offensive, and so does the country." 68 Johnston's letter illustrates the southern belief that aggressive action was the key to ultimate victory. As such, Johnston developed plans for an engagement and waited for the opportunity to strike. McClellan provided the opportunity when two of his corps crossed the Chickahominy River without support. ${ }^{69}$ Johnston immediately attacked, 
giving his subordinates detailed plans that required precise timing and close supervision to work. However, unlike Napoleon who famously prepared excessively detailed campaign orders, Johnston did not enjoy a correspondingly skillful set of subordinate generals. ${ }^{70}$ His plans also expected too much from soldiers marching over rain-soaked roads, and the attacks bogged down in inconclusive fighting. The confusion produced frustration among the Confederate ranks, and in one instance Jackson berated a colonel who failed to throw his troops into action saying, "How many men did you have killed?" "None"; "How many wounded?" "None, sir"; "Do you call that much of a fight?" Jackson ordered the colonel placed under arrest. ${ }^{71}$ During the fighting Johnston suffered two wounds in quick succession; a spent musket ball hit him in the shoulder and a shell fragment punctured his chest, injuring him severely enough to put him out of action for several months. ${ }^{72}$ His battle plans, a blend of intense European military planning and headlong southern aggression, simply did not work. But McClellan's caution led him to stop advancing after the engagement and afforded the Confederates time to rest and resupply.

After the battle, Robert E. Lee, recently returned to Richmond after a lengthy assignment overseeing the construction of fortifications on the Confederate East Coast, assumed command of the Confederate forces in Virginia. In contrast to his first combat command, Lee would not again appear tentative to his superiors or fellow officers. Longstreet compared Lee's aggression to his Union counterpart's: “As a commander [Lee] was very much of the Wellington 'Up-and-at-em' style. He found it hard, the enemy in sight, to withhold his blows. With McClellan it was more difficult to strike than to march for the enemy.",73 Another staff officer who had faith in Lee said, "His name 
might be Audacity. He will take more desperate chances, and take them quicker than any other general in this country, North or South. And you will live to see it, too. ${ }^{, 74}$ Lee first released the dashing cavalier, J. E. B. Stuart and his cavalry brigade, on a one hundred fifty mile ride around the entire Union army. ${ }^{75}$ The ride proved of little strategic consequence, but Stuart demonstrated the dashing ideal of the southern cavalier in action. His ride embarrassed and frustrated McClellan and his cavalry leaders, captured several tons of Union supplies, and boosted southern morale. The Seven Days campaign that followed revealed clearly how the South's military command believed they should conduct the war.

Lee planned his own series of complicated maneuvers to strike along a wide front of McClellan's line. Lee's plan depended on surprise, coordination, and good timing, but he also designed the plan with his enemy in mind. Like many of his fellow gentleman, Lee believed the northern officer class militarily inferior to its southern rivals, and that at the first hint of aggressive action they would fold under pressure. As one of Lee's generals, Lafayette McLaws, explained, “The Yankees themselves acknowledge our superiority of courage and spirit to themselves. They wonder how it is that our half clad, half starved soldiers can fight so well. The idea of any one fighting for principle has never for once entered their understanding. ${ }^{, 76}$ Following this haughty line of thinking, Lee planned to strike the Union army knowing that Johnston's initial offensive at Seven Pines had shaken the already timid McClellan. McClellan actually initiated contact, but quickly surrendered the initiative when his forces met determined Confederate resistance. ${ }^{77}$ But Lee did not anticipate the poor performance of his subordinates, including Jackson, and the poor coordination that hampered his attack's effectiveness. 
In the series of engagements that followed, known as the Seven Days Battles, Lee hoped to divide and destroy the widely spread Union Army of the Potomac. ${ }^{78}$ Beginning at Mechanicsville on June 28, Lee ordered his divisions to assault the Union right flank, using Jackson's troops as the lynchpin of the attack. Just returned from the Valley Campaign, however, Jackson and his soldiers were sluggish, and commenced their portion of the attack four hours later than planned. ${ }^{79}$ One of Lee's generals, John B. Magruder, while waiting for Jackson to arrive, asked Lee for permission to attack the Union lines out of sheer restlessness: "if you will allow me to do so I pledge my honor as a soldier that I will carry them at the point of the bayonet." ${ }^{, 80}$ Union artillery pounded the Confederate troops waiting to attack and Longstreet struggled to rein in his impetuous officers, many of whom were desperate to demonstrate their bravery. Longstreet noted, "I sent orders for [Colonel] Jenkins to silence the battery [harassing the waiting Confederate lines], under the impression that our wait was understood, and that the sharp-shooters would be pushed forward till they could pick off the gunners, thus ridding us of that annoyance; but the gallant Jenkins, only too anxious for a dash at the battery, charged and captured it, thus precipitating battle. ${ }^{" 81}$ Nothing came of Magruder and Jackson's assaults but high casualties and McClellan's panicked message to Abraham Lincoln claiming that he faced at least two hundred thousand enemy soldiers, rather than the something less than ninety thousand Confederates in the field. ${ }^{82}$ Lee followed the next day at Gaines's Mill with the Confederacy's largest attack of the war, nearly fifty five thousand soldiers. ${ }^{83}$ Jackson arrived late again, however, and timely Union reinforcements pushed back the attack. 
Mentally beaten by the end of the second day of the battle, McClellan, despite controlling the field, outnumbering his enemy, possessing adequate supplies and lines of retreat, and enjoying a strong defensive position, began to withdraw. The Union retreat affirmed Lee's initial assessment of McClellan. Lee had accomplished his objective of driving McClellan away from Richmond, but he launched assault after assault over the next several days, hoping to produce a rout of the Union army. McLaws revealed the Confederate hesitation to break contact during the battle, even in victory:

Yesterday our troops were engaged all day, with brilliant results, having driven the enemy in all directions, from his strongest fortifications. But the battle is not yet won, as our enemies are powerful and well provided. It is however the opinion that if we would now allow them to run they would run, but we are surrounding them ... and some desperate fighting is yet to be done. ${ }^{84}$

After a failure by Magruder to follow up a successful attack, Lee sent him a dispatch reminding him how southern generals were expected to fight: "I regret much that you have made so little progress to-day in pursuit of the enemy. In order to reap the fruits of our victory the pursuit should be most vigorous. I must urge you, then, again to press on his rear rapidly and steadily. We must lose no time, or he will escape entirely." 85 But the defensive positioning and numerical superiority of McClellan's force made Lee's strategy unlikely to succeed and Confederate casualties ballooned, especially at the final fight at Malvern Hill, where Lee gave up any pretense of nuance and tried to overrun the Union positions by sheer force. His pre-battle artillery bombardment did little damage to the Union defenders, and more than five thousand six hundred Confederates were killed or wounded. ${ }^{86}$ In one instance, Confederate officers were so desperate to get at their Union enemy that they advanced without orders. Longstreet reported: "It seems that just as the troops marched to the left under the last order, information was received by some 
of the officers at the front that the enemy was getting away from us .... Anxious to atone for lost opportunities of the day before, part of the troops near our right moved forward, and soon encountered the enemy's infantry." ${ }^{87}$ After Malvern Hill, Lee's battered and exhausted army could not contest McClellan's retreat, which did not stop until it reached the safety of northern Virginia.

The Seven Days campaign against McClellan produced a strategic victory but Lee's continued assaults, well after he had any hope of decisive victory, also made it a symbol of the waste incurred by aggressive Confederate generals. D. H. Hill, one of Lee's generals, summarized this belief after the war:

We were very lavish of blood in those days and it was thought to be a great thing to charge a battery of artillery or an earth-work lined with infantry .... The attacks on the Beaver Dam intrenchments, on the heights of Malvern Hill, at Gettysburg, etc., were all grand, but of exactly the kind of grandeur which the South could not afford. ${ }^{88}$

While Seven Days restored Lee's favor among the Confederate high command and lifted civilian morale, it also produced acute bloodletting in the Army of Northern Virginia. Sustaining the image of the aggressive southern officer led to casualty rates that the relatively limited Confederate manpower reserves could not accommodate. Still, the Confederate populace reacted positively to Lee's aggressive operations, regardless of cost. Officers already predisposed to aggressive action by upbringing and training recognized that command opportunities rested on their ability to produce via aggressive action. The Confederate officer corps was deeply impressed with Lee after the battle, and McLaws praised the man once called "Granny Lee" by noting, "The criterion in military matters is success and up to this hour the combinations of General Lee have been of the 
most marked, decided, and successful. You cannot imagine how gratifying is the feeling to soldiers, to know that their chief is competent to all positions." 89

A month after McClellan withdrew up the peninsula, a second Union force, the Army of Virginia under John Pope, marched to the aide of the Army of the Potomac, forcing Lee to make a difficult choice. If he waited for the Army of Virginia to join with McClellan he risked being crushed between the two. But if he moved against Pope, Lee knew McClellan would be free to attack Richmond. Alternatively, if Lee attacked McClellan's fortifications, he could gain little by it and suffer more casualties. Believing that waiting profited little and goaded by a staff confident in his abilities, Lee committed a small number of troops to hold McClellan in place and marched north to confront Pope. Confederate spirits, rising after their strategic victory at Seven Days, soared when they learned they were attacking again. Brigadier Isaac Trimble believed another battle would allow him to demonstrate his bravery and thereby gain promotion: "Before this war is over I intend to be a major general or a corpse." ${ }^{90}$ Lee's maneuver, by which he confronted one side of the pincer movement while occupying the other's attention, was perfected by Napoleon nearly half a century before. ${ }^{91}$ Lee sent Jackson on a flanking march, with orders to seize Manassas Junction, currently employed as Pope's central supply and communications hub. ${ }^{92}$ Once Jackson seized the junction, Pope would have no choice but to offer battle or withdraw. Jackson, recovered from the weariness that plagued him and his division after the Valley Campaign, moved around Pope's flank and expertly planted himself astride the Union line of communications. James Longstreet, one of Lee's divisional commanders, followed the sounds of the guns and arrived quickly, while Pope threw his army against Jackson's isolated division. Serious casualties piled up 
on both sides, but Longstreet's arrival on the battlefield, right behind the attacking Union army, went unnoticed. His subsequent attack crushed the Union army between his army's hammer and Jackson's unmoving anvil. ${ }^{93}$ Pope's forces fled the battle, leaving the Army of Northern Virginia its clearest victory of the war.

Lee's success at the Second Battle of Bull Run rested largely on his ability to seize the operational and tactical initiative from his Union enemies. Once Jackson captured the Manassas rail-hub, victory was largely assured if Pope did not withdraw and Longstreet continued aggressively maneuvering, which Lee could count on because of the southern cultural attachment to aggression. The southern use of aggressive tactics both Jackson's capture of Manassas rail-hub and Longstreet's maneuvering — led directly to a victory, and one attained at significantly less cost than Seven Days. Emboldened by the success aggression brought, Lee and his lieutenants looked to exploit the victory by invading Maryland. Longstreet wrote, "the situation called for action, and there was but one opening, - across the Potomac." "94 Southern leaders hoped to relieve Virginian farms from supplying the Confederate army by obtaining much needed supplies from enemy territory. ${ }^{95}$ Confederate military and political leaders also hoped that a victory on northern soil would gain formal French and British political recognition and bring Maryland slaveholders to the Confederate colors. ${ }^{96}$ Lee believed his invasion would influence the North's upcoming elections, leading to a more antiwar House of Representatives. Above all, however, Lee recognized the South's strategic and military vulnerability. No matter how many battles he won in Virginia, only the destruction of the Union's principal field armies or the capture of its capital would compel the North to sign a peace treaty. Lee's aggressive invasion of Maryland followed the Confederate 
understanding of the strategic situation, and the region's cultural values. Lee and Longstreet believed they would succeed. According to Longstreet, Lee offered Jefferson Davis, "deliberate and urgent advice to ... join him and be prepared to make a proposal for peace and independence from the head of a conquering army.,97

Beyond the practical reasons for invading Maryland, Lee's decision to march north lay deeply rooted in southern understandings of honor and masculinity and reflected the heavy toll that defensive fighting in the South took on his men. Confederate soldiers eagerly sought to visit some of the devastation and violence on northern towns that Union armies had visited upon Virginia's countryside. Southern soldiers adopted characteristically enthusiastic rhetoric about the venture and expressed deep virulence toward the enemy territory they would soon pass through. Griffin discussed the mood of the army when he wrote: "I heard several [soldiers] to day ... hope that Jeff Davis would not stop until he overran all the North and burned the principal cities, including Boston. ${ }^{98}$ McLaws echoed the sentiments of his fellow officers when he wrote before the campaign, "If we are striking for Pennsylvania we are actuated by a desire to visit upon the enemy some of the horrors of war, to give the northern people some idea of the excesses committed by their troops upon our houses and inhabitants." ${ }^{, 99}$ The wish to harm defenseless civilians may seem uncharacteristic for men who believed themselves models of gentility and moral uprightness, but their experiences in the war's first year brought another aspect of their honor culture to the fore. Constant exposure to Confederate refugees, burned-out farms, and razed villages insulted the masculinity of these men, who seemed powerless to stop the Yankee invaders. By attacking and ravaging northern 
territory, southern soldiers sought to prove that they could defend their home while demonstrating northerners' inability to defend their land.

Despite southerners' desire to burn and lay waste northern farmland, Lee forbade Confederate soldiers from plundering the northern countryside, an order to which they adhered, despite the obvious needs and interest of the army. ${ }^{100}$ McLaws wrote unhappily, "It is reported that our army will not be allowed to plunder or rob in Pennsylvania, which is all very well; but it would be better not to publish it. As we have received provocations enough to burn and take or destroy, property of all kinds and even the men, women \& children along our whole border."101 Gentility and honor won out over rage and violence, reflecting Confederates' belief that the war with the Yankees represented a clash of two different cultures and they would not compromise their values in the pursuit of victory. McLaws eventually concluded that sparing northern territory was a good idea: "We knew too well the treacherous, fiendish, Yankee character to give them any such excuse for the exercise of their natural brutality." 102 The Confederates would fight as gentlemen and not succumb to the baser actions instincts they believed were common among their northern opponent. As the war progressed and the Confederate cause became more desperate, however, southern gentility took a backseat to more cruel behaviors, especially regarding the treatment of northern property and black Union troops.

Lee and his army slipped by McClellan's forces, and moved north in several wide ranging columns. A young northern boy wrote in his diary about the Confederate soldiers as they marched past:

They were the dirtiest men I ever saw, a most ragged, lean, and hungry set of wolves. Yet there was a dash about them that the northern men lacked. They rode like circus riders. Many of them were from the far South and spoke a dialect I 
could scarcely understand. They were profane beyond belief and talked incessantly. ${ }^{103}$

Military strategy usually counseled against splitting an army, but Lee concluded that the careful McClellan would not pursue him quickly, and his army could be supplied more easily in separate columns. However, ill-luck plagued Lee's operation, including a careless officer who left a complete copy of Lee's campaign orders at an abandoned campsite. ${ }^{104}$ Union pickets discovered and delivered the orders to an exultant McClellan who declared, “Here is a paper with which if I cannot whip 'Bobby Lee,' I will be willing to go home." ${ }^{105}$ For all his bluster, however, McClellan could not completely shed his cautious nature and waited a full eighteen hours before pursuing Lee. ${ }^{106}$ Confederates discovered that McClellan had obtained a copy of their plans, but Lee refused to abandon his invasion. Perhaps he wanted to ensure the safety of some of his exposed divisions or perhaps he believed he could win a defensive battle. Lee recognized his extreme vulnerability and realized that McClellan had the opportunity to destroy his army piecemeal. But rather than withdraw to Virginia, declare the campaign a failure, and start over again at a later date, Lee decided to fight, issuing orders to his far-flung commanders to assemble at Antietam Creek, Maryland.

Lee had nearly fifty five thousand men during the campaign, but he could only gather thirty nine thousand soldiers near Antietam before McClellan attacked. ${ }^{107}$ Though Lee's decision to remain in Maryland was fundamentally flawed, his tactical conduct at Antietam was notable. McClellan's numerically superior force attacked throughout the day in wave after wave against the thin Confederate lines, but Lee managed to repulse every attack by carefully managing his interior lines, never letting McClellan exploit any 
gap that appeared. ${ }^{108}$ Lee launched aggressive attacks whenever he could, even against overwhelming enemy forces, as Brigadier General John Bell Hood observed:

Not far distant in our front were drawn up, in close array, heavy columns of Federal infantry; not less than two corps were in sight to oppose my small command, numbering, approximately, two thousand effectives. Notwithstanding the overwhelming odds of over ten to one against us, we drove the enemy from the wood and corn field back upon his reserves, and forced him to abandon his guns on our left. This most deadly combat raged till our last round of ammunition was expended. [We] had lost, in the corn field, fully two-thirds of [our] number; and whole ranks of brave men, whose deeds were unrecorded save in the hearts of loved ones at home, were mowed down in heaps to the right and left. ${ }^{109}$

This episode demonstrates the unwillingness to disengage, common among the Confederate leaders even in the face of overwhelming numbers, that cost them dearly. McClellan, for his part, never achieved a force concentration large enough to drive home any of his attacks, in large part because he refused to commit several divisions that could have turned the Confederate defeat into the complete destruction of Lee's army. ${ }^{110}$ For his part, Lee demonstrated an understanding of European tactics unmatched by other American commanders, but his cultural affinities proved costly. The southern belief that retreat meant cowardice or dishonor chained Lee to a decision — remaining in Maryland — that ignored sound military judgment. At one point, the fighting became so closely contested that D. H. Hill, one of Lee's generals, "seized a musket and by example speedily collected a number of men, who joined him in reinforcing the line threatened by this heavy display." 111 Lee's decision resulted in the bloodiest day in American military history, as Confederate and Union forces shredded one another for nearly twelve hours. The battle almost crippled the Army of Northern Virginia, with Lee losing 11,724 men, or 22.6 percent of his entire force. ${ }^{112}$ Narrowly avoiding complete destruction, Lee limped back into friendly territory without having gained the desperately needed decisive 
engagement. The Confederates gained no strategic advantage from his decision to fight, despite the severe losses incurred at Antietam. ${ }^{113}$

Antietam represented a defining battle of the Civil War and offered a clear demonstration of southern battle culture. Retreat would have saved Lee's army, but it would have required abandoning Maryland allies and southern conquests. Equally important, retreat entailed a public loss of face. The Maryland Campaign and its bloody conclusion highlight how the South's honor culture could lead to disastrous decisions. Lee, and to a lesser extent, Longstreet and Jackson, decided to hold the line at Antietam because they viewed retreat without battle as tantamount to failure. Even though Lee conducted a defensive battle, tactics aggressive southern commanders did not favor, simply deciding to fight was aggressive. Besides strategic concerns, the South's willingness to fight in northern territory also demonstrated the region's honor culture. Without a contest of arms to confirm or deny the legitimacy of their invasion, retreat represented cowardice. Instead of withdrawing to the safety of northern Virginia the Confederate high command decided to fight. In short, the Confederate army conducted the battle defensively, but by refusing to withdraw from Union territory without a fight, still demonstrated their attachment to the honor culture.

While the Confederates in the East pressed their advantage after Second Bull Run, the Confederate armies in the West contemplated their own offensive maneuvers into Union territory. Much like Lee, the commanders in the West sought decisive 
engagements against the Federal armies opposing them. After replacing P. G. T. Beauregard as the commander of the Army of Tennessee, Braxton Bragg reworked Confederate strategy and determined to strike north. Bragg redeployed several subordinate armies in a shield stretching from Arkansas through Mississippi, in an effort to slow Ulysses Grant, currently maneuvering against the vital Confederate city of Vicksburg. He ordered General Edmund Kirby Smith to join him in the North, and each slipped past their Union pursuers into Kentucky. Bragg and Smith believed, like Lee, that an invasion would benefit larger Confederate strategic goals, encouraging sympathetic Kentuckians to rally to the Confederate colors while eliminating the need to supply themselves from southern farms. ${ }^{114}$ After an easy entry into Kentucky, Bragg confidently told his soldiers: "Comrades, our campaign opens most auspiciously and promises complete success .... The enemy is in full retreat, with consternation and demoralization devastating his ranks. To secure the full fruits of this condition we must press on vigorously and unceasingly." ${ }^{, 15}$ Bragg and Smith faced the cautious and southernsympathizing Don Carlos Buell, but they failed to combine their forces during the ensuing battle for the state. Despite seizing the Kentucky capital of Frankfort, their campaign failed, partially because they wasted time and effort interfering in Kentucky's state politics. ${ }^{116}$ Confederate forces facing numerical deficiencies could ill-afford to split their strength in the face of larger Union armies, especially in enemy territory. While this practice worked at Second Bull Run, it significantly undermined the Confederate invasion of Kentucky.

Buell, disinclined to force a battle with the invading Confederate armies, pursued Bragg slowly through Kentucky, until Union forces stumbled into Confederate forces 
outside the town of Perryville. Bragg opted to attack the larger Union army and sent notes to Smith to join him when he realized the potential to defeat Buell, who had divided his command in an effort to locate the Confederates. ${ }^{117}$ Bragg told his officers, "A powerful foe is assembling in our front and we must prepare to strike him a sudden and decisive blow." ${ }^{118}$ With Buell several miles behind the main army when the battle began, Bragg's aggression created confusion among the Union command staff. Bragg attacked along the Union left, driving Union forces before him, but the attack sputtered as reinforcements reached Federal lines. The Confederates continued to launch halfhearted attacks, but slowed by the heat and a lack of water, failed to capitalize on earlier breakthroughs. ${ }^{119}$ As Union reinforcements arrived, Bragg withdrew, hoping to join with the tardy Smith and renew his advance. However, Bragg soon learned of the Confederate defeat at Antietam in the East and further Union advances in the West and decided to abandon Kentucky. Bragg won a tactical victory, but the battle cost him nearly 20 percent of his force killed or wounded. ${ }^{120}$ Bragg and Smith withdrew from Kentucky, with nothing to show for their aggressive invasion. The twin Confederate thrusts north ended in failure, with combined casualties of nearly twenty thousand men, irreplaceable losses for a military desperate to preserve its manpower.

Lee and Bragg's invasions of the North provide excellent case studies for understanding southern aggression. Each campaign reflected applications of military thought by attempting to put pressure on presumed weak points in the enemy's defenses. ${ }^{121}$ Lee and Bragg both believed that the border states represented the North's weak link, and cultural inclinations to take the war to the North supplemented good military and strategic sense. Neither campaign proved successful, though not because of 
flaws in the strategic thinking. Lee's Maryland campaign failed because of mischance and an unwillingness to withdraw, while Bragg's failed because he did not have enough men on hand to exploit his success at Perryville, especially because of Smith's dallying and Lee's defeat at Antietam. Failures in application rather than flaws in planning foiled southern expansion. Lee's stubbornness cost the South dearly at Antietam, and Bragg's inability to link with Smith made it impossible to sustain his invasion of Kentucky. Strategic aggression might have succeeded if not for operational and tactical failures. Equally important, both commanders showed a similar cultural imperative that led them to invade northern territory. Separated by hundreds of miles and never in direct communication, Lee and Bragg acted aggressively because their cultural background reinforced what they believed the correct military decision. In effect, strategic formulations did not necessarily require direct oversight by the Confederate War Department because individual army commanders shared the belief that successful prosecution of the war required aggressive action. Their invasions fused military rationality with the seeming irrationality of southern aggression. In Lee's case, his continued attachment to aggression led to defeat, showing how southern culture could negatively impact military judgment.

Both Confederate armies withdrew to safe territory and began to rebuild. Fortunately for the Army of Northern Virginia, new Union General Ambrose Burnside launched a piecemeal and weak attack in December 1862 against Lee's strong winter positions around the town of Fredericksburg. Despite the Confederate preference to attack, Lee and his commanders could not believe their good fortune when Burnside decided to offer battle. Begun at the height of the inactive season for most armies of the 
era, Burnside's attack gave Lee and his army the opportunity to inflict a large number of casualties with relatively little risk to their position. ${ }^{122}$ After the bloodletting of the Maryland campaign, even the most hotheaded southern commanders could not pass up the opportunity to fight defensively from their prepared positions at Fredericksburg. At the cost of only five thousand men, Lee's army killed or captured more than twelve thousand Union soldiers who marched straight toward the well supported defensive lines of Lee's men, much to the horror of the northern public. ${ }^{123}$

Lee's success in the defensive battle at Fredericksburg has prompted scholars to wonder why he did not attempt to fight more of these types of battles, especially considering his overwhelming success. Defensive battles certainly benefited a manpowerstrapped Confederacy, but Lee rarely found such fights operationally possible. A string of careful Union commanders often surrendered the initiative to Lee, who was both militarily and culturally inclined to pursue an aggressive policy. Military conditions made continuous defensive posture unlikely, while cultural influences made it odious. Lee and other military leaders well remembered his derisive title "Granny Lee" and the southern public's love for dashing figures like Jackson and Stuart. As long as gallantry, masculinity, and courage endured as important regional cultural paradigms, southern military leaders remained chained to the offensive. Only crippling manpower shortages curbed this tendency much later in the war. Fredericksburg thus represents an anomaly in 1862, a tactical choice that reflected the exhaustion of the Confederate army after Antietam and the poor decision-making of Burnside, who lost thousands of soldiers without damaging Lee's position. ${ }^{124}$ 
In the West, Bragg and his fellow generals suffered through an abysmal few months in the fall of 1862, first defeated at Iuka and then thoroughly repulsed during an offensive at Second Corinth. The latter battle is especially revealing, as the Confederates won the first day's fighting, overcoming prepared Union rifle pits with determined bayonet charges. ${ }^{125}$ On the second day, however, the Confederate commanders, Earl Van Dorn and Sterling Price, hurled their divisions against a second set of carefully organized entrenchments, this time backed by Union artillery and gun emplacements, and turned an initial Confederate success into an overwhelming Union victory. ${ }^{126}$ The defeats at Iuka and Corinth, though smaller in scale than Bragg's or Lee's campaigns, demonstrated that regardless of force size, Confederate commanders believed attack the foremost way to fight with honor. Even when sound military thought demonstrated otherwise, Confederate commanders could not detach themselves from the southern culture that guided their actions.

In response to the losses at Iuka and Second Corinth, Bragg felt compelled to accomplish at least one successful campaign before the end of the year. At the Battle of Stones River in the first days of 1863, Bragg contrived to surprise the Union Army of the Cumberland, in the same way that Albert Sidney Johnston and P. G. T. Beauregard surprised Grant at Shiloh earlier in the war. The commander of the Army of the Cumberland, William Rosecrans, knew of Bragg's forces operating in his vicinity, and planned for battle when he felt ready. However, Bragg seized the initiative, and two divisions crashed into the Union right early on the morning of December $31 .{ }^{127}$ Sweeping aside several Union brigades in the middle of finishing breakfast, Confederate forces ruptured large portions of the Union line, forcing Rosecrans to tighten and reform his 
line. Despite the casualties incurred on the first day, Bragg resolved to attack again if Rosecrans did not retreat. While raiding Union supply lines, Confederate cavalry discovered large numbers of Union troops escorting wounded soldiers north, which they interpreted as Rosecrans's withdrawal. ${ }^{128}$ Rather than wait for the Union departure and therefore the completion of his campaign's objectives, Bragg launched more assaults. Well entrenched and supported by strong artillery emplacements, Union defenders blasted away at the Confederate lines, turning what at first appeared to be a victory into a decisive defeat. ${ }^{129}$ Bragg withdrew to Tullahoma, leaving Murfreesboro to the now unopposed Rosecrans.

Stones River demonstrated again that Confederate commanders could not abandon their aggressive style of fighting, even when they had little reason to continue to fight that way. As at Shiloh, attacks on the second day of Stones River could not accomplish more than the surprise attacks on the first. Confederate commanders again salvaged defeat from the jaws of victory by refusing to relinquish the tactical initiative. Bragg's failure at Stones River proved especially glaring. Repeated Confederate attacks concentrated the Union defense, and when Bragg fed southern reinforcements into battle too slowly Rosecrans met each attack individually. In many ways, the battle resembled a reversal of Antietam, as the defending Union army survived poorly coordinated Confederate attacks by manipulating their interior lines. After Stones River, the Confederates in the West struggled to reverse the seemingly inexorable push by Union forces. $^{130}$

Following the defensive victory at Fredericksburg, Lee and Jackson decided to resume their aggressiveness by attacking Joseph Hooker's Army of the Potomac as it 
marched parallel to Lee's previous entrenchments. Hooker believed that he could simply overwhelm Lee's army, which was half the size of his one hundred thirty thousand man force. He reportedly boasted, "May God have mercy on General Lee, for I will have none." 131 To accomplish what he assumed would be an easy victory, Hooker planned to swing his army's corps along a wide frontage, making it impossible for Lee to escape his net. Though a complicated and difficult plan to carry out in the heavily wooded areas through which the armies maneuvered, Hooker's superior numbers gave him a distinct advantage. Despite a smooth start, Hooker soon lost confidence, fearing that his plans were too complicated and the initiative once again devolved to the Confederates. ${ }^{132}$

In early May 1863, Lee and Jackson seized the initiative, but then violated the same important military axiom Bragg and Smith disregarded at Perryville, by dividing their forces in front of larger Union armies. Marching across Hooker's front at Chancellorsville to attack the Federal flank and rear, which was "in the air," Lee's gamble depended on the suddenly hesitant Hooker to remain in place, and the Union general obliged. ${ }^{133}$ Through the early afternoon Jackson led his corps around the Union flank, careful to screen his movements with Confederate cavalry. Hooker assumed reports of marching Confederate forces were Lee beginning a retreat, and relieved that he needed to take no immediate action stood his ground. Once in position, Jackson's Confederate units crashed through Union army encampments, where most of the Army of the Potomac was sitting down for dinner. ${ }^{134}$ Jackson routed the entire XI Corps, shattering it in just two hours. But friendly fire in the dim light of early evening left Jackson mortally wounded, and Lee's subsequent attacks lacked the momentum of the earlier charges and could not dislodge entrenched Union reinforcements. ${ }^{135}$ For his part, 
Hooker was a beaten man and began a steady withdrawal north as soon as he had the opportunity, awaiting further orders from President Lincoln.

After the failures at Iuka, Second Corinth, and Stones River, Confederate forces in the West faced a difficult proposition. Union forces, advancing south from their bases in western Tennessee, resumed their campaign against the vital city of Vicksburg, Mississippi. By the spring of 1863, despite setbacks, Grant advanced toward Vicksburg with armies totaling nearly seventy five thousand men. ${ }^{136}$ Confederate forces numbered roughly half that number, dispersed between the Vicksburg garrison under John C.

Pemberton and Joseph E. Johnston's independent command. ${ }^{137}$ Despite holding such an important post, Pemberton was not actually a southerner. Born and raised in Pennsylvania, he joined the Confederate Army due largely to the influence of his Virginian wife, and during the campaign his reluctance to attack angered his aggressive southern subordinates. ${ }^{138}$ Grant's initial movements appeared to the Confederates as the beginning of a conservative campaign in which he would use his numerical superiority to wear down their forces. In response, Pemberton believed he could harass Grant's supply lines that stretched all the way back to Tennessee and force him to withdraw. ${ }^{139}$ Pemberton told Johnston he preferred to outlast Grant instead of attacking aggressively, noting, "I am a northern man; I know my people." ${ }^{140}$ Pemberton believed that his plan, rooted in understanding that a hot and sickly summer climate in Mississippi would affect Grant's men more than his southerners, would enable the Confederates to conserve their outnumbered forces.

Pemberton's poor generalship, partially a product of his background, produced one of the feeblest Confederate operations of the war. During Grant's advance Pemberton 
launched a few halfhearted attacks before Grant disposed of his supply lines and slipped by his confused Confederate pursuers. Exploiting local farms and towns, Grant supplied his army independently of his overstretched supply lines and with no fixed objective to attack, Pemberton withdrew. ${ }^{141}$ Johnston, maneuvering near Pemberton's forces, urged the Vicksburg garrison commander to find and immediately attack Grant:

I am anxious to see a force assembled that may be able to inflict a heavy blow upon the enemy .... If prisoners tell the truth, the force at Jackson must be half of Grant's army. It would decide the campaign to beat it, which can only be done by concentrating, especially when the remainder of the eastern troops arrive .... Can [Grant] supply himself from the Mississippi? Can you not cut him off from it, and above all, should he be compelled to fall back for want of supplies, beat him. ${ }^{142}$

Meanwhile, Grant's chief subordinate, Sherman, captured Jackson, Mississippi, giving Grant a base from which to lay siege to Vicksburg. ${ }^{143}$ Pemberton drew up his army at Champion Hill twenty miles east of Vicksburg to make a stand. But strong Union attacks drove back his forces and compelled him to withdraw into the city. Once Grant surrounded Vicksburg the city would inevitably fall unless reinforcements came. Johnston and other military leaders urged Pemberton to break out, but he refused. ${ }^{144}$ Lacking enough soldiers to attack Grant's siege lines and relieve the city, Johnston withdrew and left Vicksburg to its fate. The surrender of nearly thirty thousand soldiers and the Confederacy's most important western city proved a decisive blow to the Confederate cause. As Grant observed, "The fall of the Confederacy was settled when Vicksburg fell. ${ }^{, 145}$ In a campaign in which the Confederacy desperately needed to act aggressively it lacked leaders capable of making those decisions. Entrusting Vicksburg to Pemberton, a man with strong prewar military experience, but without southern aggressiveness, resulted in Confederate encirclement and defeat. William Chambers, a 
junior officer in Pemberton's force, wrote, "Some of us wept ... for we realized that this was the end of all our sacrifices. For this ignoble ending we had fought ... had hungered, had shed our blood." ${ }^{146}$ He accused Pemberton of selling out the southern army to his northern brethren: "[Pemberton] had been false to the flag under which he fought." ${ }^{147}$ In this instance, the cultural aggressiveness that cost Confederate armies dearly at Shiloh and Antietam might have saved Vicksburg, but was never applied. The fall of Vicksburg crushed the likelihood of a significant Confederate victory in the West. ${ }^{148}$ After the Battle of Chancellorsville, it fell to Robert E. Lee and the Army of Northern Virginia to take the war to northern territory again.

\section{$* * *$}

The Army of Northern Virginia won its most impressive victory at Chancellorsville, but it cost the life of its best divisional commander, as well as more than thirteen thousand casualties. ${ }^{149}$ Other tactically similar battles like Shiloh, Second Corinth, Stones River, Chickamauga, and the Wilderness proved too costly for Confederates forces to follow up. But Chancellorsville, like Second Bull Run, afforded Lee an opportunity to revive his plans for an invasion of Pennsylvania. Slipping past the cowed Hooker, Lee divided his poorly supplied army and advanced north, assuming correctly that his adversary would be doubly cautious after his defeat at Chancellorsville. Hooker's tentativeness prompted President Lincoln to replace him with George Gordon Meade, who set off in quick pursuit. ${ }^{150}$ Meade wanted to bring Lee to battle, especially once he realized that Lee had dispersed his army to search for supplies. Lee also suffered 
from a lack of information, as J. E. B. Stuart foolishly rode around the entire Union army again, capturing supplies, destroying railroads, and cutting telegraph wires. ${ }^{151}$ Though an impressive feat, Stuart's ride cost his commander vital information about Meade's movements upon which the campaign hinged. In early July 1863, Lee's army made contact with the Union army accidentally outside the town of Gettysburg, and Lee quickly called his scattered divisions to assemble.

After conferring with his generals, Lee decided his best plan of action would be to attempt to repeat his actions at Second Bull Run. Though his inability to discover the whereabouts of the Army of the Potomac before stumbling into it meant he could not choose a battlefield to his liking, Lee remained confident of victory. He and his lieutenants hoped to invite a Union attack if possible, and smash the Army of the Potomac against their forces lying in wait. ${ }^{152}$ However, the Battle of Gettysburg developed significantly differently, largely because Lee and some of his generals changed their minds before the battle. Longstreet remembered the moment Lee altered his battle plans:

[Lee] had announced beforehand that he would not make aggressive battle in the enemy's country. After the [field] survey and in consideration of his plans, noting movements of detachments of the enemy on the Emmitsburg road, the relative positions of manoeuvre, the lofty perch of the enemy, the rocky slopes from it, all marking the position clearly defensive, — I said, "We could not call the enemy to position better suited to our plans. All that we have to do is to file around his left and secure good ground between him and his capital." This, when said, was thought to be the opinion of my commander as much as my own. I was not a little surprised, therefore, at his impatience, as, striking the air with his closed hand, he said, "If he is there to-morrow I will attack him.,"

Longstreet inadvertently revealed the two sides of Confederate military thinking.

First, Lee and his officers developed a solid plan that involved slipping by Meade, dictating a place of battle suitable to their plans, and then baiting the enemy into attacking 
them. That plan, reminiscent of the famous French victory at Austerlitz that generals of the era thought the perfect battle, made sound operational sense. Napoleon baited a trap into which the Austrian and Russian enemies fell, allowing him to counterattack so forcefully that he destroyed both of their armies as effective fighting forces for several years. ${ }^{154}$ Southern commanders believed that replicating Napoleon's plan was militarily feasible and prudent, if ambitious. However, southern cultural impulses often preempted good military planning. As Longstreet noted, upon seeing the enemy, Lee changed the plans and decided to attack. Lee's decision reveals Confederate commanders' deeply rooted need to strike first, rather than waiting passively. And that the entirety of Lee's command staff, with the exception of Longstreet, agreed to the change, points to the shared cultural imperatives of the commander and his officers. ${ }^{155}$

Over the first two days of the battle, Lee hammered the Union line, which held on despite severe losses. Confederate losses were grave as well, especially among the officer corps. Longstreet, upon discovering one of his colonels mortally wounded on the field, agreed to take a note written in blood to the dying man's father, which read, "I died with my face to the enemy." 156 On the third day, nearly twelve thousand five hundred Confederate soldiers charged the heart of Union artillery and infantry entrenchments. ${ }^{157}$ During Pickett's Charge, as the attack became known, a now familiar Confederate tactical pattern played itself out on a massive scale, and withered under Union guns. A Confederate officer recalled, "[We] pressed on to within about twenty or thirty paces of the [enemy's] works — a small but gallant band of heroes daring to attempt what could not be done by flesh and blood. The end soon came. We were beaten back to the line from which we had advanced with terrible loss, and in much confusion." 158 
Lee's decision to attack on the third day at Gettysburg represents one of the clearest instances of how southern battle culture shaped Confederate tactical decisions. A skillful commander in the European military tradition, Lee's decision to attack straight into the toughest part of the Union line assumed his soldiers could overcome their numerical deficiencies, the strength of the Union lines, and the distance they had to cross to reach the Union defenders. Lee's confidence came from something other than military reason. At Gettysburg, Lee and his generals attacked because they believed in the superiority of their men, the concept of aggression, and that military sacrifice was a component of success. Before Lee ordered the attack he remarked, "There never were such men in an army before .... They will go anywhere and do anything if properly led. The enemy is there, and I'm going to strike him.. ${ }^{, 159}$ Pickett's reckless charge, led from the front by southern officers determined to gain military glory, proved a brutal failure. The honor culture that drove officers' actions prompted their enlisted men to follow them into the teeth of the Union line. The decision to launch an attack on such well-prepared Union lines could only have come from a commander and a society sure of its military superiority. Lee wrote after the battle:

The conduct of the troops was all that I could desire or expect, and they deserve success so far as it can be deserved by heroic valor and fortitude. More may have been required of them than they were able to perform, but my admiration of their noble qualities and confidence in their ability to cope successfully with the enemy has suffered no abatement. ${ }^{160}$

The defeat at Gettysburg marked the turning point in the eastern theatre, just as surely as the fall of Vicksburg did in the West. ${ }^{161}$ During the first years of the war the Confederacy enjoyed significant advantages in confidence and military preparedness. However, they largely squandered these advantages by 1863 . The decline of Confederate 
military fortunes was directly linked to prewar notions of military participation and behavior. Confederate commanders time and again launched tactically unwise assaults that represented a poor fusion of military education and cultural inclinations to fight aggressively. Southern notions of bravery, aggression, and honor helped supplement a broad base of military knowledge among the Confederate military command. However, instead of creating a military structure that benefited from its martial education and honor-based upbringing, it created a system in which aggression dominated military affairs. During the first years of the war Confederate commanders planned and fought battles that reflected what they understood as good military decision-making. Guided by an overweening belief that the war could be won by instigating major battles instead of fighting defensively or relying on guerrilla operations placed a significant strain on the resources of the South. In a society in which bravery represented a vitally important component of manhood these attacks guaranteed that officers and men alike would put themselves in harm's way at an alarming rate.

Culturally inclined to attack and carry out their orders, the Confederate military bloodied itself thoroughly during the first years of the war. By the conclusion of the Battle of Gettysburg and Siege of Vicksburg, the Confederacy had largely crippled itself through its own actions. Nonetheless, the South fought on for two more years, continuing to express the same assurance of victory that characterized its first years. As the end of the war approached, however, their rhetoric changed. As chapter three explores, the belief that defeat approached never quite took hold among the South's military leaders. Only when Lee surrendered at Appomattox and other generals began to surrender their commands did the Confederacy understand that the end was at hand. Narratives began to 
change from defiance, pride, and belief in ultimate success to a desire to fight honorably until the bitter end, or die trying. If chapter two is the story of the Confederacy at the height of its aggressiveness, chapter three explores the stubbornness of the Confederacy as it came to grips with its collapse and notions of "defeat with honor."

${ }^{1}$ McWhiney and Jamieson, Attack and Die, 179.

${ }^{2}$ John Keegan, The American Civil War: A Military History (New York: Random House, Inc., 2009), 200.

${ }^{3}$ William Faulkner, Intruder in the Dust (New York: The Modern Library, 1948), 195.

${ }^{4}$ Keegan, The American Civil War, 197.

${ }^{5}$ McLaws, A Soldier's General, 194.

${ }^{6}$ Sword, Southern Invincibility, 144.

${ }^{7}$ William W. Freehling, The Road to Disunion Volume I: Secessionists at Bay, 17761854 (New York: Oxford University Press, 1990), 277.

${ }^{8}$ Robert V. Remini, Andrew Jackson and the Course of American Freedom, 1822-1832 vol.2. (Baltimore: The John Hopkins University Press, 1981), 382-89.

${ }^{9}$ Bruce Catton, The Civil War (Boston: Houghton Mifflin Company, 1960), 19.

${ }^{10}$ Keegan, The American Civil War, 33.

${ }^{11}$ Ibid., 33.

${ }^{12}$ McArthur, A Gentleman and an Officer, 285-86.

${ }^{13}$ Robert Leckie, None Died in Vain: The Saga of the American Civil War (New York: Harper Perennial, 1990), 138-39.

${ }^{14}$ Keegan, The American Civil War, 34.

${ }^{15}$ Catton, The Civil War, 24.

${ }^{16}$ Keegan, The American Civil War, 35.

${ }^{17}$ Leckie, None Died in Vain, 140.

${ }^{18}$ David J. Eicher, The Longest Night: A Military History of the Civil War (New York: Simon \& Schuster, 2001), 53.

${ }^{19}$ Catton, The Civil War, 26.

${ }^{20}$ Thomas, The Confederate Nation 1861-1865, 109.

${ }^{21}$ Richard M. McMurry, Two Great Rebel Armies: An Essay in Confederate Military History (Chapel Hill: University of North Carolina Press, 1989), 110. This prewar military experience typically represented military service with the United States Army, training at a military school, or service in the state militia.

${ }^{22}$ John Brown Gordon, Reminiscences of the Civil War (New York: Charles Scribner's Sons, 1903), 11-12.

${ }^{23}$ Phillips, Diehard Rebels, 5.

${ }^{24}$ Keegan, The American Civil War, 49.

${ }^{25}$ Ibid., 49.

${ }^{26}$ William F. Fox, Regimental Losses in the American Civil War, 1861-1865: A Treatise on the Extent and Nature of the Mortuary Losses in the Union Regiments, with Full and 
Exhaustive Statistics Compiled from the Official Records on File in the State Military

Bureaus and at Washington (Albany: Brandow Printing Company, 1898), 558.

${ }^{27}$ Ibid., 558.

${ }^{28}$ Thomas L. Livermore, Numbers and Losses in the Civil War in America: 1861-1865

(Bloomington: Indiana University Press, 1957), 2.

${ }^{29}$ Fritz, Voices in the Storm, 105.

${ }^{30}$ Gordon, Reminiscences of the Civil War, 19.

${ }^{31}$ McWhiney and Jamieson, Attack and Die, 160.

${ }^{32}$ McArthur, A Gentleman and an Officer, 132-33, 150.

33 Ibid., 47.

${ }^{34}$ Sword, Southern Invincibility, 34.

35 James M. McPherson, Battle Cry of Freedom: The Civil War Era (New York: Oxford

University Press, 1988), 296.

${ }^{36}$ Eicher, The Longest Night, 98.

${ }^{37}$ Leckie, None Died in Vain, 161.

${ }^{38}$ Foote, The Civil War, a Narrative: Fort Sumter to Perryville, 448.

${ }^{39}$ McLaws, A Soldier's General, 99.

${ }^{40}$ Jubal Anderson Early, A Memoir of the Last Year of the War for Independence in the Confederate States of America: Containing an Account of the Operations of His

Commands in the Years 1864 and 1865. Edited by Gary W. Gallagher (Columbia, SC:

University of South Carolina Press, 2001), 11.

${ }^{41}$ Leckie, None Died in Vain, 164.

42 Ibid., 345.

${ }^{43}$ For further reading on the Battle of Bull Run, see William C. Davis, Battle at Bull Run: A History of the First Major Campaign of the Civil War (Baton Rouge: Louisiana State University Press, 1981); Ethan S. Rafuse, A Single Grand Victory: The First Campaign and Battle of Manassas (Wilmington, DE: Rowan \& Littlefield Publishers, 2002); and Alan Hankinson, First Bull Run 1861: The South's First Victory (Westport, CT: Praeger, 2004).

${ }^{44}$ Gordon, Reminiscences of the Civil War, 72.

${ }^{45}$ Douglas Southall Freeman, R. E. Lee: A Biography. 4 vols. (New York: Charles

Scribner's Sons, 1934), vol. 1, 602.

${ }^{46}$ Catton, The Civil War, 33.

${ }^{47}$ Eicher, The Longest Night, 168-171.

${ }^{48}$ Catton, The Civil War, 60.

${ }^{49}$ McPherson, Battle Cry of Freedom, 407.

${ }^{50}$ William C. Davis, The Cause Lost: Myths and Realities of the Confederacy (Lawrence: University Press of Kansas, 1996), 127-28.

${ }^{51}$ Eicher, The Longest Night, 223.

${ }^{52}$ Weigley, The Age of Battles, 368.

${ }^{53}$ McPherson, Battle Cry of Freedom, 408.

${ }^{54}$ Ibid., 410.

55 John Richard Stephens, Commanding the Storm: Civil War Battles in the Words of the Generals Who Fought Them (Guilford, CT: Lyons Press, 2012), 69-70.

${ }^{56}$ Eicher, The Longest Night, 227. 
${ }^{57}$ Leckie, None Died in Vain, 288.

${ }^{58}$ For further reading on the Battle of Shiloh, see Larry J. Daniel, Shiloh: The Battle That Changed the Civil War (New York: Simon \& Schuster, 1997); James L. McDonough, Shiloh, in Hell Before Night (Knoxville: University of Tennessee Press, 1977); and Steven E. Woodworth, The Shiloh Campaign (Carbondale: Southern Illinois University Press, 2009).

${ }^{59}$ Stephens, Commanding the Storm, 70.

${ }^{60}$ Foote, The Civil War, a Narrative: Fort Sumter to Perryville, 567.

${ }^{61}$ Keegan, The American Civil War, 143-44.

${ }^{62}$ McPherson, Battle Cry of Freedom, 454.

${ }^{63}$ McLaws, A Soldier's General, 146.

${ }^{64}$ Thomas, The Confederate Nation 1861-1865, 224.

${ }^{65}$ Leckie, None Died in Vain, 188.

${ }^{66}$ Ibid., 191.

${ }^{67}$ McPherson, Battle Cry of Freedom, 5.

${ }^{68}$ McWhiney and Jamieson, Attack and Die, 161.

${ }^{69}$ Eicher, The Longest Night, 276.

${ }^{70}$ During Napoleon's military dominance of the European continent, he was ably served by a series of marshals capable of understanding and implementing his military dictums. The most important of these dictums, that his generals "march to the sound of the guns" helped guide his subordinates, even when Napoleon was not physically present to give them orders. Napoleon appointed twenty-six marshals during his reign, and only one was killed in battle. By contrast, Confederate generals were willing to expose themselves to fire, leading to high casualty rates. The consistent turnover among Confederate officers made experience at the staff level less prevalent as the war went on, and negatively impacted the Confederate military's effectiveness. See Jonathon Riley, Napoleon As a General: Command From the Battlefield to Grand Strategy (New York: Hambledon Continuum, 2007) for more information on Napoleon's generalship and the role of his senior officers on the battlefield.

${ }^{71}$ Foote, The Civil War, a Narrative: Fort Sumter to Perryville, 452.

${ }^{72}$ Eicher, The Longest Night, 278.

${ }^{73}$ James Longstreet, From Manassas to Appomattox: Memoirs of the Civil War in America (New York: De Capo Press, 1896), 288.

${ }^{74}$ Foote, The Civil War, a Narrative: Fort Sumter to Perryville, 478.

${ }^{75}$ Eicher, The Longest Night, 280.

${ }^{76}$ McLaws, A Soldier's General, 160.

${ }^{77}$ Keegan, The American Civil War, 146.

${ }^{78}$ Ibid., 146-47.

${ }^{79}$ McPherson, Battle Cry of Freedom, 466.

${ }^{80} \mathrm{~J}$. Williams Jones, Life and Letters of Robert Edward Lee, Soldier and Man (New York: The Neale Publishing Company, 1906), 176.

${ }^{81}$ Longstreet, From Manassas to Appomattox, 135.

${ }^{82}$ McPherson, Battle Cry of Freedom, 464.

${ }^{83}$ Ibid., 467.

${ }^{84}$ McLaws, A Soldier's General, 147-48. 
${ }^{85}$ Longstreet, From Manassas to Appomattox, 150.

${ }^{86}$ Eicher, The Longest Night, 293-96.

${ }^{87}$ Longstreet, From Manassas to Appomattox, 144.

${ }^{88}$ McWhiney and Jamieson, Attack and Die, 108.

${ }^{89}$ McLaws, A Soldier's General, 148.

${ }^{90}$ Foote, The Civil War, a Narrative: Fort Sumter to Perryville, 618.

${ }^{91}$ Interior lines are a concept of maneuver warfare in which the area occupied by the defending force is smaller than the area controlled by the attacker. In military terms, armies operating on their interior lines occupy a smaller space to move, supply, and defend while their opponent occupies the space surrounding that area of maneuver.

Armies fighting on their interior lines often do so because they are outnumbered and must concentrate rapidly against isolated enemy forces in an effort to avoid envelopment. Napoleon became famous for his ability to manipulate his interior lines against his enemies, which had the effect of making his armies seem larger, avoid being overwhelmed, and prevent concentration against him. Lee's later defense at Antietam and Meade's at Gettysburg are textbook examples of the exploitation of interior lines. J. C. Dundas, "The Strategy of Exterior and Interior Lines in the Light of Modern War" Royal United Services Institution, Journal 66 (1921), 101-113.

${ }^{92}$ Leckie, None Died in Vain, 353.

93 Ibid., 355.

${ }^{94}$ Longstreet, From Manassas to Appomattox, 200.

95 Ibid., 279. Longstreet wrote, "The commercial, social, and blood ties of Maryland inclined her people to the Southern cause. A little way north of the Potomac were inviting fields of food and supplies more plentiful than on the southern side; and the fields for march and manoeuver, strategy and tactics, were even more inviting than the broad fields of grain and comfortable pasture-lands. Propitious also was the prospect of swelling our ranks by Maryland recruits."

${ }^{96}$ Eicher, The Longest Night, 336-337.

${ }^{97}$ Longstreet, From Manassas to Appomattox, 204.

${ }^{98}$ McArthur, A Gentleman and an Officer, 88.

${ }^{99}$ McLaws, A Soldier's General, 188.

${ }^{100}$ Eicher, The Longest Night, 339.

${ }^{101}$ McLaws, A Soldier's General, 190.

102 Ibid., 162.

${ }^{103}$ Foote, The Civil War, a Narrative: Fort Sumter to Perryville, 663.

${ }^{104}$ Catton, The Civil War, 95.

${ }^{105}$ Leckie, None Died in Vain, 369.

${ }^{106}$ Keegan, The American Civil War, 167.

${ }^{107}$ Leckie, None Died in Vain, 371.

${ }^{108}$ Keegan, The American Civil War, 167.

${ }^{109}$ Stephens, Commanding the Storm, 84-85.

${ }^{110}$ Ibid., 168. Force concentration is the military process of applying the most force against the enemy's point of least resistance. Jackson discussed the theory during his Shenandoah Valley Campaign: "Always mystify, mislead, and surprise the enemy, if possible. And when you strike and overwhelm him, never let up in the pursuit so long as 
your men have strength to follow; for an army routed, if hotly pursued, becomes panicstricken, and can then be destroyed by half their number. The other rule is, never fight against heavy odds if by any possible maneuvering you can hurl your own force on only a part of it, and that the weakest part, of your enemy and crush it. Such tactics will win every time, and a small army may thus destroy a large one in detail, and repeated victory will make it invincible." Foote, The Civil War, a Narrative: Fort Sumter to Perryville, 464.

${ }_{111}^{111}$ Longstreet, From Manassas to Appomattox, 253.

${ }^{112}$ Eicher, The Longest Night, 363.

${ }^{113}$ For further reading on the Battle of Antietam, see David S. Hartwig, To Antietam Creek: the Maryland Campaign of September 1862 (Baltimore: Johns Hopkins University Press, 2012); Stephen W. Sears, Landscape Turned Red: the Battle of Antietam (New York: Houghton Mifflin Company, 2003); and James M. McPherson, Crossroads of Freedom: Antietam (New York: Oxford University Press, 2002).

${ }_{115}^{114}$ McPherson, Battle Cry of Freedom, 517.

${ }^{115}$ Foote, The Civil War, a Narrative: Fort Sumter to Perryville, 656.

${ }^{116}$ Bragg and Smith hoped that inaugurating a southern-sympathizing government in Frankfort would aid the legitimacy of their campaign and promote recruitment in the state. To that end they occupied Kentucky's state capital and inaugurated a Confederate state governor, Richard Hawes. The invasion's failure meant Kentucky's Confederate state government spent the war in exile.

${ }^{117}$ Bragg was the senior Confederate commander in the West, but Kirby Smith's army was an independent force created by special order of President Davis. Bragg sent Smith several notes insisting that they combine and face Buell together, but Smith demurred, knowing that linking with Bragg would cost him his independence. Bragg could not directly order Smith to join him, and Bragg sorely missed Smith's army at the Battle of Perryville.

${ }_{118}^{118}$ Foote, The Civil War, a Narrative: Fort Sumter to Perryville, 660.

${ }^{119}$ Leckie, None Died in Vain, 402.

${ }^{120}$ McPherson, Battle Cry of Freedom, 520.

${ }^{121}$ Correct application of force concentration was a hallmark of the era's greatest generals. Marlborough, Frederick the Great, and Napoleon all employed similar tactical patterns during their battles to achieve superior force concentration. Civil War generals were acutely aware of the thought process involved in putting pressure to the enemy's weakest point, but applying this understanding on the battlefield proved no simple task. McClellan's failure at Antietam and Ambrose Burnside's failure at Fredericksburg offer two examples of Union generals failing to exploit their numerical superiority to overwhelm smaller Confederate forces.

${ }_{122}$ Leckie, None Died in Vain, 406-407.

${ }^{123}$ Joseph T. Glatthaar, General Lee's Army: From Victory to Collapse (New York: Free Press, 2008), 175.

${ }^{124}$ For further reading on the Battle of Fredericksburg, see George C. Rable, Fredericksburg! Fredericksburg! (Chapel Hill: University of North Carolina Press, 2002); and Gary W. Gallagher, ed., The Fredericksburg Campaign: Decision on the Rappahannock (Chapel Hill: University of North Carolina Press, 1995). 
${ }^{125}$ Leckie, None Died in Vain, 395.

126 Ibid., 397.

${ }^{127}$ Keegan, The American Civil War, 177.

${ }^{128}$ Eicher, The Longest Night, 423.

${ }^{129}$ McPherson, Battle Cry of Freedom, 582.

${ }^{130}$ For further reading on the Battle of Stones River, see Earl J. Hess, Banners to the Breeze: The Kentucky Campaign, Corinth, and Stones River (Lincoln: University of Nebraska Press, 2000); Larry J. Daniel, Battle of Stones River: The Forgotten Conflict Between the Confederate Army of Tennessee and the Union Army of the Cumberland (Baton Rouge: Louisiana State University Press, 2012); and Peter Cozzens, No Better Place to Die: The Battle of Stones River (Chicago: University of Illinois, 1990).

${ }^{131}$ McPherson, Battle Cry of Freedom, 639.

132 Ibid., 640.

${ }^{133}$ Leckie, None Died in Vain, 443.

${ }^{134}$ Keegan, The American Civil War, 182.

${ }^{135}$ McPherson, Battle Cry of Freedom, 642-44.

${ }^{136}$ Leckie, None Died in Vain, 453-54.

${ }^{137}$ Keegan, The American Civil War, 206, 209.

${ }^{138}$ Leckie, None Died in Vain, 551-52.

${ }^{139}$ Keegan, The American Civil War, 214.

${ }^{140}$ Shelby Foote, The Civil War, a Narrative: Red River to Appomattox (New York: Vintage Books, 1986), 355.

${ }^{141}$ Keegan, The American Civil War, 214-15.

${ }^{142}$ Foote, The Civil War, a Narrative: Red River to Appomattox, 336.

${ }^{143}$ Catton, The Civil War, 134.

144 Ibid., 134.

${ }^{145}$ Keegan, The American Civil War, 219.

${ }^{146}$ Sword, Southern Invincibility, 193.

147 Ibid., 193.

${ }^{148}$ For further reading on the Battle of Vicksburg, see Michael B. Ballard, Vicksburg: the Campaign that Opened the Mississippi (Chapel Hill: University of North Carolina Press, 2010); Shelby Foote, The Beleaguered City: The Vicksburg Campaign, December 1862July 1863 (New York: Modern Library, 1995); and Winston Groom, Vicksburg, 1863 (New York: Alfred A. Knopf, 2009).

${ }^{149}$ McPherson, Battle Cry of Freedom, 645.

${ }^{150}$ Keegan, The American Civil War, 190.

${ }^{151}$ McPherson, Battle Cry of Freedom, 653.

152 Ibid., 653-54.

${ }^{153}$ Longstreet, From Manassas to Appomattox, 358.

${ }^{154}$ Weigley, The Age of Battles, 389.

${ }^{155}$ Keegan, The American Civil War, 196.

${ }^{156}$ Longstreet, From Manassas to Appomattox, 375.

${ }^{157}$ Catton, The Civil War, 140.

${ }^{158}$ McWhiney and Jamieson, Attack and Die, 179.

${ }^{159}$ Sword, Southern Invincibility, 177. 
${ }^{160}$ Ibid., 173.

${ }^{161}$ For further reading on the Battle of Gettysburg, see Bruce Catton, Gettysburg: the Final Fury (New York: Doubleday, 1974); Carol Reardon, Pickett's Charge in History and Memory (Chapel Hill: University of North Carolina Press, 1997); Stephen W. Sears, Gettysburg (Boston: Houghton Mifflin, 2003); and Allen C. Guelzo, Gettysburg: the Last Invasion (New York: Alfred A. Knopf, 2013). 


\section{CHAPTER 3: DEFIANCE, DECLINE, AND DOWNFALL: THE CIVIL WAR FROM THE OVERLAND CAMPAIGN TO APPOMATTOX COURTHOUSE}

In one of his most widely known and important works, The Sound and the Fury, William Faulkner wrote, "I give you the mausoleum of all hope and desire; I give it to you not that you may remember time, but that you might forget it now and then for a moment and not spend all your breath trying to conquer it. Because no battle is ever won he said. They are not even fought. The field only reveals to man his own folly and despair, and victory is an illusion of philosophers and fools." ${ }^{\text {A }}$ After the Battle of Gettysburg and the fall of Vicksburg, the possibility of southern victory eroded, even though the Confederacy continued to fight. However, the poor prospects of the Confederate armies had little impact on the attitude of the military elite who led them on battlefields from Texas to Virginia. Despite suffering two devastating defeats and surrendering nearly thirty thousand men at Vicksburg, little changed in their rhetoric or actions. Contrary to good military sense, the Confederate military leadership made little substantive change in their aggression or intention to conduct the war as men of honor. Their predilection to continue fighting the war aggressively never wavered, though acute losses increasingly hampered them. However, as men of honor, they remained defiant, even in the face of the catastrophic losses they suffered. As an officer from Georgia put it, "We who fight for our wives and children, our homes, and property cannot be whipped, to conquer us is to kill us."2 
Chapter three examines how Confederate generals conducted their campaigns as the possibility of victory steadily diminished after Vicksburg and Gettysburg through the end of the war. During the first years of the war Confederate generals and the white populace remained confident that victory would result from a war conducted by honorable gentlemen, according to southern cultural imperatives. They believed that the South, long known as the more militaristic, brave, and honorable part of the United States, could not be defeated by a nation far less motivated and valiant. But even after victory became less certain, the Confederacy continued to wage what they believed to be an "honorable war." Their commitment to this cultural imperative also enabled them to surrender peacefully, without turning the major southern armies into guerrilla forces to continue the fighting. Cultural commitments made it difficult for Confederate generals to change their tactics when the war turned against them. Ultimately, they ended the war according to their understanding of honor, or only when the Union army forcibly battered down their military resistance.

The Confederate generals' conceptions of "honorable warfare" had its roots in Western military history. During the eighteenth and nineteenth centuries, warfare developed organically from the ideals of the Enlightenment, Scientific Revolution, and Romantic Era. ${ }^{3}$ Western Europe's aristocracy, long influenced by chivalric notions of military service, played a pivotal role in the development and maintenance of European armies during the dynastic wars of the eighteenth and nineteenth centuries. ${ }^{4}$ As a German military theorist explained, "The nobility derives its origins, and most of its privileges, from the military establishment of our ancestors." Even when non-noblemen and professionals became part of the military command structure during and after the French 
Revolution, the belief that command belonged to the "best-men" never wavered.

Southern aristocrats in 1861 embraced the message of a European military memorandum written in 1781, "[the nobility] knows no other condition of life, no profession other than that of arms." ${ }^{, 6}$ European military officers believed that war, despite its horrors, could be fought honorably and they consequently accorded even their enemies certain favors and respect. ${ }^{7}$ Officers who fought gallantly could expect good treatment, but cowards and fools could not. During the eighteenth century these practices became informally codified so that generals under siege knew how many days of bombardment they must endure, how many sorties to launch, and how close the enemy's artillery had to come to the walls before it became acceptable to open surrender negotiations. ${ }^{8}$ The French Revolution certainly changed the professional attitude of Europe's officer corps, but the idea that gentlemen could conduct warfare honorably remained extremely important.

Confederate generals, who believed themselves the inheritors of Europe's nobility and military doctrine, adapted these concepts to the Civil War. Though they believed their enemy did not come from the same noble stock bequeathed to southerners by their cavalier ancestors, Confederate officers thought that they should conduct the war honorably. Men of higher social stature had to lead armies because they were the South's natural leaders who understood the finer points of military tactics and civil governance. A war conducted by their social inferiors, they assumed, would devolve into brutality. ${ }^{9}$ The prevailing trends of warfare that influenced both Confederate and Union generals had changed little since the late 1700s, but southern generals, unlike their northern counterparts, attached cultural dimensions to their military service. ${ }^{10}$ While the North certainly had a class of individuals who qualified as an economic elite, its members did 
not see military service as a necessary component of their cultural identity like the southern aristocracy. ${ }^{11}$ Northern officers studied prevailing military standards and practices, but were less immersed in the "gentlemanly" aspects of war than their southern counterparts. Though northern men remained keenly aware of their honor and masculinity, military service was not required to attain or reinforce their status as honorable men. Northern honor derived from upright moral character and economic success, making physical violence and aggression less important. ${ }^{12}$ The absence of slavery in the North, and the correspondingly strict social hierarchy that flowed from its racial stratification, meant that northern conceptions of honor were less communally dependent than in the South. ${ }^{13}$ Conversely, Confederate officers went to great lengths to aggressively demonstrate their honor in battle, creating a series of unspoken protocols that formed the basis of southern battlefield conduct.

Confederate generals proved they were honorable men by behaving courageously on the field, aggressively pursuing action, shunning cowardice, and acting in accordance with other masculine paradigms of antebellum southern elite culture. However, as the war turned against the Confederacy, and especially after Vicksburg and Gettysburg, many officers began to question how best to salvage a victory. Instead of changing tactics and becoming more conservative during campaigns, the major Confederate armies continued to fight aggressive actions and as late as fall of 1864 still planned to invade northern territory. ${ }^{14}$ During the latter half of the war the behavior of Confederate generals followed two crucial patterns. First, Confederate officers did not change their tactics in the face of overwhelming losses. Indeed, an obsession with dying in battle or destroying the invading Union forces became the primary objectives for many Confederate officers. 
Second, once the hopelessness of the Confederate position became apparent to the military elite, they began conceptualizing their objectives as less strategic and more honor-based. Multiple Confederate generals concluded that surrender might be an option, but only if they believed they had satisfied their honor and the honor of their army, usually by wasting their commands attacking Union forces late in the war.

The Confederacy's last year and a half of the Civil War were substantially different from the first two years of the conflict. After the defeats at Vicksburg and Gettysburg the South lacked the population resources to undertake offensive campaigns into Union territory. This situation, coupled with the inexorable push of Ulysses S. Grant in the East and William T. Sherman in the West, transformed the war. Seizing the strategic initiative enabled Union forces to open several major campaigns against Confederate cities and strongpoints. Even when Robert E. Lee or John Bell Hood, who replaced Braxton Bragg and Joseph E. Johnston, led attacks against Union armies, they could do no serious damage to the Union war effort. Lee inflicted heavy casualties on Union forces at Wilderness, Spotsylvania Court House, Cold Harbor, and Petersburg, but Grant could afford his climbing casualty rates more than the Confederacy. Grant's style of campaigning, which often appeared overly costly to contemporaries, looks impressive in hindsight. He watched for years the effect of Confederate aggression in both theatres, and understood that only the application of overwhelming force and the continuous concentration of armies in the South's territory could overthrow the Confederate military. 
His strategy required the application of the North's prodigious population, industrial, and material resources and it worked perfectly. Grant's continued hammering of Lee's army, though bloody, prevented Lee from regaining the aggressive initiative that fueled the early successes of the Confederacy's military. However, Grant's victories came at a cost, and his decision to launch attack after attack against Confederate field trenches and fortifications presaged the waste of later World War I battles. ${ }^{15}$

The defeats at Vicksburg and Gettysburg snapped the defensive lines of the Confederates in the West, and permanently wrecked the offensive capabilities of the Army of Northern Virginia. More than sixty-four thousand Confederate soldiers were killed, wounded, or captured during the two campaigns. ${ }^{16}$ Hindsight makes the South's defeat seem inevitable, but the southern population and military did not believe defeat was certain after 1863. Newspapers, private diaries, and a host of other material attest to the fervent belief of Confederate soldiers and private citizens that the war could still reach a favorable conclusion, despite the demoralization that accompanied the 1863 defeats. ${ }^{17}$ As Fred Fleet, a soldier in the Army of Northern Virginia explained in 1864, "If you could only see the Army, you would never feel any anxiety about Richmond. Lee is stronger than when the fighting commenced \& his men, as well as those of the gallant Beauregard are in the best possible trim."18 Even in the waning days of the war, white southerners hoped that foreign recognition would arrive along with troops from France and Britain. ${ }^{19}$ In this fantasy, Lee would defeat Grant and march north, and the Union advance in the West would bog down in the innumerable waterways and tributaries of the Mississippi River. Major Thomas Elder remarked in 1864, "I think the Yankees and the rest of mankind must soon come to the conclusion that the South cannot be subjugated."20 
Though fervently believed, these pipe-dreams did not reflect the reality of the war. The Confederacy's prospect of winning declined sharply after it lost the capacity to take the war into northern territory. Lincoln's 1864 reelection and Grant's unrelenting campaign in the South meant that the war's end was only a matter of time. Despite their diminishing offensive capabilities, Confederate armies continued to attack when tactical and operational opportunities made it possible. But these offensive operations only prolonged a war the South was increasingly unlikely to win. Lee's surrender at Appomattox and his decision not to use his army in a guerrilla war amounted to formalities, despite their symbolic and cultural importance. Confederate forces spent four years aggressively seeking a decisive battle, but did not gain it, and in the last years of the war southern officers made futile attempts to give a losing defensive war some sort of positive momentum.

After their successes in the Gettysburg and Vicksburg campaigns, Union forces gained the strategic initiative and began a multi-pronged offensive in September 1863, aimed at wresting control of Tennessee and Virginia from the Confederacy. As a first step, Union army forces applied pressure to Braxton Bragg's forces defending Chattanooga. Well aware of the danger of such a loss, Confederate leaders had discussed releasing units from the Army of Northern Virginia to help in the West, even before the Gettysburg campaign. James Longstreet, anticipating a western command before Vicksburg fell, said that, "honor, interest, duty, and humanity called us to that service," and asked the War Department to send reinforcements from Lee's army to the West. ${ }^{21}$ Longstreet and many of his fellow generals believed that military good sense, as well as honor, required propping up failing generals like Bragg in the western theatre. After 
Vicksburg fell, Longstreet was sent to the West, and assigned to Bragg's endangered command. As the more senior commander, Longstreet bristled at being placed under Bragg, thinking it an insult to his honor:

A soldier's honor is his all, and of that they would rob him and degrade him in the eyes of his troops. The occasion seemed to demand resignation, but that would have been unsoldierly conduct. Dispassionate judgment suggested, as the proper rounding of the soldier's life, to stay and go down with faithful comrades of long and arduous service. ${ }^{22}$

Longstreet's complaints certainly suggest that the same honor culture that buttressed the South's social hierarchy before the war shaped the command structure of the Confederate military. Longstreet soon became the leader of a group of officers determined to push Bragg out of his command. ${ }^{23}$ Unlike Lee, Bragg had chosen not to launch an aggressive campaign after his defeats at Perryville and Stones River. These disasters and his timidity alienated him from the generals on his staff, who repeatedly wrote to Confederate President Jefferson Davis asking that Bragg be stripped of his command. Though initially opposed to removing Brag, Davis became convinced of the need to act after the fall of Vicksburg and Bragg's inability to come to the city's aide. Accordingly, Davis sent the partially recuperated Joseph E. Johnston to Bragg's Army of Tennessee with the stated purpose of making sure the army was ready for battle. Secretly, Johnston sought to ascertain whether he should assume command and take the war north again by attacking William Rosecrans's Army of the Cumberland, then threatening Chattanooga. While Johnston decided not take command because of the lasting effect of his wound at Seven Pines and the exhausting Vicksburg campaign, his visit stiffened Bragg's resolve to resume the offensive. Despite the Confederacy's recent military losses, southerners expected their generals to take aggressive action or step down from 
military command. One Confederate explained that after the fall of Vicksburg: "war policy ... must be no dilly-dallying, no tardiness, no timidity in our counsels. We must fight ever, fight bravely, and contend for every inch of ground, falling back only when our warm and patriotic blood shall have watered \& dyed the soil of the sunny South." 24 Bragg's new campaign started poorly, when Rosecrans launched his own offensive to sever Bragg's hold on Chattanooga. Meanwhile, Longstreet and his corps from the Army of Northern Virginia commenced its three-week journey to reinforce Bragg. Before Longstreet arrived, however, Rosecrans outmaneuvered Bragg, smoothly and nearly bloodlessly slipped past the Army of Tennessee, and seized the city. ${ }^{25}$ Unable to counter Rosecrans's position effectively, Bragg withdrew from the city's environs into the hills outside of town. By the time Longstreet and his reinforcements arrived, Bragg had decided to attack Rosecrans, who had seriously overstretched his supply lines to take Chattanooga. Bragg notified his officers: "I shall promptly assail him in the open field with my whole available force, if he does not exceed me more than four to one." 26 Bragg's force numbered sixty-five thousand men, meaning he was willing to attack the Union army if it did not exceed two hundred and sixty thousand soldiers, a staggering differential. Bragg's willingness to attack exemplified the southern understanding of battle — attack at all costs, regardless of military reason.

The battle began on September 19, when Confederate forces ran into Union pickets encamped perilously close to southern lines. Once the general engagement began, Bragg committed heavy reinforcements to each of his successive attacks across the wide Federal front. Though unable to break through the Union lines at any point over several hours of fighting, Bragg resolved to continue the Confederate assaults the next day, 
despite suffering as many as eight thousand casualties. Bragg's reckless determination to maintain his aggressive position paid off on the second day, when a mistaken communication among Rosecrans's lieutenants caused a gap to open in the center of the Federal lines. ${ }^{27}$ Meanwhile, Bragg, impatient that attacks on the Union left had floundered, ordered Longstreet's corps to advance, into what should have been the center of the Union defenses. Instead of significant resistance, Longstreet's forces overwhelmed the few defenders and began to roll up the Union right. Union forces, thrown into a panic by the sudden collapse of their lines, tried to reform along a series of ridges astride the Union left.

Confederate forces, thanks to good fortune, and in spite of serious mishandling by Bragg, had completed their objectives beyond their highest expectations. The defeated Union forces, their supply lines cut off, had to withdraw to Chattanooga, where Bragg could open a siege at his convenience. Instead of waiting for the Union's certain withdrawal, however, Bragg continued to attack. But by this point, Union forces had dug in to their positions and clung to their only route of escape. Bragg's continued attacks made little military sense, and severely weakened his army by wasting men in fruitless attacks. ${ }^{28}$ Indeed, Longstreet estimated that he ordered as many as twenty five separate assaults against the heavily defended Horseshoe Ridge on the last day of the battle. ${ }^{29}$ Bragg's attack highlights the subjugation of military good sense to the South's cultural and social impetus to demonstrate aggression and bravery. Even though he secured a victory, Bragg's conduct at Chickamauga resulted in more than eighteen thousand Confederate casualties, including nine ranking generals. ${ }^{30}$ On the third day of the battle, 
an exhausted and battered Union Army of the Cumberland withdrew into Chattanooga, to await Bragg's encirclement of the city. ${ }^{31}$

After Bragg commenced the siege of Chattanooga, he quarreled with his chief generals, accusing them of failing to bring him an absolute victory. His subordinates, including Longstreet, mutinied, and only the intervention of the War Department and the suspension of several officers alleviated the problem. ${ }^{32}$ Longstreet was dispatched to counter a Union thrust by Ambrose Burnside to seize Knoxville. Longstreet waged a strong campaign, but in the climatic engagement at Fort Sanders, his force incurred nearly nine hundred casualties trying to break strongly fortified Union lines, while only thirteen Union soldiers were killed or wounded in the assault. ${ }^{33}$ Longstreet argued that attack was the only way to victory at Knoxville, writing, "I am entirely convinced that our only safety [was] in making the assault upon the enemy's position."34 Longstreet failed to prevent the fall of Knoxville, and was crucially absent when Grant began his campaign to relieve the Army of the Cumberland, now commanded by George $\mathrm{H}$. Thomas, at Chattanooga.

Armed with reinforcements from successful campaigns elsewhere, Grant defeated Bragg's halfhearted attempts to destroy his supply lines at Wauhatchie. After he entered Chattanooga, Grant ordered Thomas to attack Bragg's forces on the high ground outside of the city. At Lookout Mountain and Missionary Ridge, Union forces advanced uphill against entrenched Confederate forces and thoroughly defeated them. Bragg was forced to withdraw in shame, and the Confederate defeat opened the Deep South to penetration by Union forces for the first time in the war. ${ }^{35}$ After the battle, a colonel from Alabama expressed the mood of the army thusly: "Everybody, both officers and men, seems to be 
ashamed of our defeat. I honestly believe that it will have a good effect upon the troops. When they get a chance to meet the enemy again they will pay him back with interest."36 A Georgia artillerist offered: "We have been overpowered in numbers and met with serious reverses. I hope that out of this disaster some good may yet come ... . I never want to leave this army till we have punished the Yankees who drove us from Missionary Ridge." ${ }^{37}$ Bragg offered his resignation, believing that President Davis would reject it. But Davis could not overlook Bragg's meandering prosecution of the siege of Chattanooga and embarrassments at Lookout Mountain and Missionary Ridge. Davis accepted the resignation because of the Confederate defeat at Chattanooga, and because he found Bragg's timid behavior, which enabled Grant to relieve the city, intolerable. ${ }^{38}$ Many Confederate soldiers in the Army of Tennessee rejoiced at Davis's decision. As an officer from Georgia explained, "We want now at the head of this army some general who will act with boldness and follow up every advantage he may gain. This army will fight with all the desperation and valor displayed at Chickamauga, for they are heartily ashamed of their conduct at Missionary Ridge."39

Joseph E. Johnston, tasked with preventing William T. Sherman from seizing Atlanta, replaced Bragg. The ensuing Atlanta Campaign highlights the consequences for Confederate generals unwilling or unable to pursue vigorous action. Beginning with a timid Johnston in command and ending with the much more aggressive John Bell Hood leading the Confederate army, the Confederates hoped to prevent Union capture of one of the South's largest cities. Sherman's objective was twofold: attack and destroy Johnston's army, or outmaneuver him and seize Atlanta. Taking Atlanta would capture one of the last major railroad hubs in the South and severely curtail distribution of crucial food and 
military supplies within the Confederacy. ${ }^{40}$ In response, Johnston planned a delaying campaign, aiming to extend Sherman's line of supply and strike only when he could gain a significant advantage. Johnston earned a reputation as an aggressive commander during his time commanding the Army of Northern Virginia, but since his wounding at Seven Pines in 1862 he had become cautious and his campaign against Sherman consisted far more of parrying Sherman's repeated attacks than landing any of his own. In the ten principal engagements between the two, Sherman initiated nine. ${ }^{41}$ The one outlier occurred when a brash Hood decided to attack Sherman without orders from Johnston.

By early July, many of Johnston's subordinate generals had become disgruntled with Johnston's unwillingness to give battle. Corps commander William Hardee despaired: "If the present system continues we may find ourselves at Atlanta before a serious battle is fought." ${ }^{42}$ Led by the well liked and dashing, if physically disabled, Hood, the officers petitioned Davis to change command. ${ }^{43}$ Johnston felt his honor was threatened, and wrote to one of his friends to explain his behavior: "I learn that it is given out that it has been proposed to me to take the offensive with a large army, \& that I refused. Don't believe any such story. I have been anxious to take the offensive." ${ }^{, 44}$ Braxton Bragg, acting as Davis's advisor in Richmond after his resignation, headed to Georgia to determine who was at fault for the timid campaign. Hood told Bragg, "I have, General, so often urged that we should force the enemy to give us battle as to almost be regarded reckless by the officers high in rank in this army [Johnston], since their views have been so directly opposite." 45

Davis, convinced that Johnston was the problem, asked Robert E. Lee what he thought of the young Hood, who had been one of Lee's division commanders. Lee's 
affirmative response, though brief, spoke volumes about what he considered important in a field commander: "[Hood is] a bold fighter, very industrious on the battlefield, careless off." ${ }^{46}$ Major Charles S. Venable described Hood's love for battle to famous Virginian diarist, Mary Boykin Chesnut, who noted: "[Venable] had often heard of the light of battle shining in a man's eyes. He had seen it once — when he carried to Hood orders from Lee, and found in the hottest of the fight that the man was transfigured." 47 Before appointing Hood, Davis hoped to induce Johnston to attack Sherman's army, telling him that he would receive no reinforcements unless he started an offensive. ${ }^{48}$ When Johnston refused, Davis decided to replace the older, tentative commander. The allure of appointing the brave and aggressive Hood, despite his inexperience, reflected southern cultural imperatives. Despite Hood's track record of personal audacity, he was largely unfit to command a full field army, and soon led his army to aggressive battle regardless of the costs. Hood's promotion was Davis's last desperate gamble to rekindle some of the offensive spirit that made Bragg's Kentucky campaign of 1862 so inspiring to the southern populace. ${ }^{49}$ Hood's command of the Army of Tennessee proved a disaster for the Confederate military.

$* * *$

Several months after Rosecrans seized Chattanooga, Union forces began preparations for a much larger campaign in the East. Ulysses Grant, newly appointed commander-in-chief of all Federal forces, ordered George Meade, the victor at Gettysburg, to gather forces for a renewed invasion of Virginia. ${ }^{50}$ Lincoln hoped his 
appointment of Grant would address the problems that consistently vexed Union leadership in the years preceding Gettysburg. Grant's predecessors in command of the Army of the Potomac — George B. McClellan, John Pope, Ambrose Burnside, and Joseph Hooker were substantially less skilled than Grant, but they also proved less willing to deploy Union forces aggressively and risk battle. After each defeat they suffered at the hands of southern commanders, previous Union generals had retreated, giving the Confederacy the opportunity to resupply, gather more soldiers, and regain the strategic initiative. ${ }^{51}$ Their actions reflected the era's style of warfare, in which defeated generals typically retreated and gave control of the field to the victor. Grant believed this pattern of warfare prolonged the war, and provided Lee with the time he needed to resume serious offensive action. In contrast, Grant planned to follow Lee and force him to fight a continuous string of battles. Even when beaten, Grant remained in the field, so that Lee could not regain the initiative. ${ }^{52}$

Grant's style of warfare promised significantly more casualties because campaigns did not end in a single battle. Instead, contact became unrelenting, and attrition replaced maneuver, making it impossible for the Confederacy to replace its losses. Grant's attritional war relied on Union logistical, manpower, and economic strengths, while highlighting the same Confederate weaknesses. Longstreet, for one, dismissed Grant's astute strategy as dishonorable: "the policy of attrition which became a prominent feature during [the Overland] campaign ... showed that the enemy put his faith in numbers more than in superior skill and generalship." ${ }^{, 53}$ Lee adopted a simple response to Grant: break the inexorable push by destroying the Union army. He told his officers, "As far as I can judge there is nothing to be gained by this army remaining 
quietly on the defensive." ${ }^{, 54}$ Within weeks of his defeat at Gettysburg, he was ready to take offensive action again, writing to Longstreet, "I hope you will use every exertion to prepare the army for offensive operations, and improve the condition of our men and animals. I can see nothing better to be done than to endeavor to bring General Meade out and use our efforts to crush his army while in its present condition." ${ }^{, 55}$ To succeed, he needed to fight decisively and aggressively before Grant and Meade could overwhelm him.

In early May 1864, Grant's forces crossed the Rapidan River and moved south. Grant knew Lee's forces were shadowing him near the old Chancellorsville battlefield, but believed Lee would not force a fight so soon after his river crossing. Lee's plan remained consistent with southern battle strategy: find the enemy and fight them. $\mathrm{He}$ wrote to Davis, "[M]y object has been to engage him [Grant] when [his army is] in motion and ... I shall continue to strike him whenever opportunity presents itself." ${ }^{, 56}$ Lee capitalized on the fact that Grant did not believe Confederate forces ready to give battle. He also realized the terrain would negate the Union Army's considerable advantage in artillery. Lee waited to attack until Grant's army became entangled in the dense collection of woodlands and shrubs known as the Wilderness. The thick woods precluded artillery support and made the Union's considerable numerical discrepancy — Grant had more than one hundred twenty thousand soldiers to Lee's sixty thousand — less glaring. ${ }^{57}$ The battle soon devolved into a brutally confused mix of attack and counterattack that ultimately hinged on Grant's ability to recognize where Confederate attacks would occur. One of Lee's corps commanders, Richard Ewell, led the first surprise assault of the day, concentrating on the extreme right of the Union line, anchored along the Orange Court 
Turnpike, one of the area's largest roads. Control of these roads proved vitally important because of the difficulties in maneuvering large forces through the dense wilderness, which caught fire several times during the battle, and burned hundreds of wounded soldiers to death. ${ }^{58}$ Lee's engineers found an abandoned train track to the left of the Union line, and began another assault along this relatively clear avenue.

Despite the element of surprise, the Confederate attacks bogged down as Union forces raced reinforcements to threatened areas and countered both thrusts. Committing Longstreet's units along the abandoned railroad on the second day of the fighting produced little change, but by that point Lee's attacks largely accomplished their objectives. The Confederate forces severely mauled the Union army, which suffered more than seventeen thousand killed, wounded, or captured, compared to about eleven thousand Confederates. ${ }^{59}$ However, the aggression of the Confederate high command produced little change in the strategic outlook of the campaign, because Grant would not concede defeat. Instead, he readjusted his frontage and planned to move around Lee. Grant wanted to interpose himself between Lee and Richmond, forcing Lee into another series of attacks, this time at a place of Grant's choosing. The Battle of the Wilderness had little impact on the campaign, save for its severe bloodletting, but it demonstrated clearly the strategic imperatives of Lee and his commanders. Despite their bloody repulse at Gettysburg, and the overwhelming numbers brought to bear against them in the campaign, they still opted for aggressive action. During the first week of fighting Lee lost twenty of his fifty-seven infantry brigade, division, and corps commanders. ${ }^{60}$ Even with the war turning against them, the South would not alter its conduct because the region's 
notions of honor would not allow its commanders to shrink from an aggressive style of warfare.

Confederate scouts reported to Lee that the pontoons Grant used to cross the Rapidan River were gone, indicating the Grant did not plan to withdraw like so many defeated Union commanders before him. ${ }^{61}$ When Lee realized that Grant would not retreat, he shifted units south, hoping to seize the crucial crossroads at Spotsylvania Court House to deprive Union forces of a convenient way through the Wilderness. Grant, well aware of the road's usefulness, also shifted his forces south in a race against Lee. Confederate cavalry detachments under Lee's nephew, Fitzhugh Lee, reached the crossroads first, and despite Union advances into the town, J. E. B. Stuart's cavalry drove them out. The exhausted Confederates, suddenly in possession of a fixed point of defense, did something relatively alien, and began to dig in, expecting a major attack. While earthworks had become a staple of sieges and fortifications, especially in the Confederate West, the Overland Campaign represented the beginning of widespread entrenchments for Confederate forces in the East, specifically in preparation for battle. ${ }^{62}$

The concept of entrenching on campaign, though increasingly common for Union soldiers as the war progressed, remained anathema to Confederate forces because it assumed they would fight a defensive battle, contrary to the demands of the southern honor code. Lieutenant General Stephen D. Lee was appalled: “A general who resorts to entrenchments, when there is any chance of success in engaging in the open field, commits a great error." ${ }^{, 3}$ Earlier in the war, Longstreet wrote that, "[Digging in] seemed strange [to Brigadier] General [Robert] Toombs, however, as he was known to have frequent talks with his troops, complaining of [Union commanders] holding the army 
from battle, digging and throwing up lines of sand instead of showing lines of battle, where all could have fair fight." ${ }^{, 64}$ Bragg remarked that rather than providing strong physical and mental reassurances they negatively impacted his units: "[Fighting from] heavy entrenchments demoralizes our troops. ${ }^{, 65}$ Though present in the operations before Seven Days, Confederate forces in the East did not begin to utilize field fortifications systematically until later in the war. However, by mid-1864, even the most ardent of aggressive Confederate military leaders began to recognize the usefulness of field entrenchments to shield the desperately shrinking pool of available soldiers. ${ }^{66}$

The entrenchments at Spotsylvania proved valuable almost immediately, enabling Confederate forces to repulse Union forces racing to the area and inflict heavy casualties. Realizing the value in holding his position rather than launching another bloody assault so soon after the Battle of the Wilderness, Lee brought up his entire army and wrapped them around the major roads, daring Grant to drive him from his strong defensive positions. In response, Grant launched a fact-finding assault along much of the Confederate line, hoping to find a weakness to exploit. After several bloody failures, Grant managed to penetrate parts of the Confederate line, before being driven off. Next he launched large numbers of men along narrow fronts, hoping to overrun the outnumbered Confederate defenders. The attack had some initial success, but again Confederate forces, employing especially well-placed artillery, drove Union troops back. Grant launched more men at the Confederate line's major salient, known as the "Bloody Angle," and casualties began to mount on both sides. ${ }^{67}$ Confederate engineers hastily built a secondary line behind the first, and after hours of intense fighting southern forces limped back to the safety of the new line, essentially negating the hard-won Union gains. 
Over the next several days, Grant continued to try to march around the flanks of the fortifications, rather than launch another frontal attack. Lee realized that Grant's constant reorientation of his lines left the Union northern flank exposed or "in the air" and he summarily sent Ewell on a reckless attack to turn Grant's flank. But Ewell's aggressive attack failed, adding hundreds of Confederate casualties to the ledger. By the end of the fighting at Spotsylvania, Confederate forces had suffered another twelve thousand casualties to Grant's losses of about eighteen thousand. ${ }^{68}$ Despite again doing more damage to Federal forces than they suffered, Confederate fortunes continued to diminish. Lee simply could not replace his losses and Grant would not concede the field after defeat.

In fact, Grant immediately tried to turn Lee's flank again, this time by racing him to the crossing of the North Anna River. Lee's forces again arrived first, but this time Grant hesitated to cross the river in range of Confederate entrenchments, and contented himself with a series of bloody skirmishes across the water. Unable to turn Lee's flank at North Anna, he moved south again, aiming for the important crossroads at Cold Harbor. ${ }^{69}$ This time Union cavalry won the race, but Lee's forces managed to construct a series of intricate field fortifications that Grant would have to attack head-on if he wanted to move any further. Grant obliged, precipitating one of the most lopsided battles of the war. Union forces attacked the Confederate earthworks over the course of several days, sometimes marching straight into Confederate forces so well entrenched behind earthwork parapets, that many Union soldiers could not see their targets. ${ }^{70}$ At the cost of roughly five thousand casualties, Lee's entrenchments helped him inflict more than twelve thousand casualties on Grant's forces, essentially replicating his defensive victory 
at Fredericksburg in $1862 .{ }^{71}$ Cognizant of the climbing casualty figures and cries of "butcher" from the northern public, Grant still tried to turn Lee's flank for the third time, finally succeeding. Lee was forced to withdraw south, before digging in for a siege outside the important rail hub of Petersburg, which protected the outskirts of the Confederate capital at Richmond. Despite some brief attacks on Lee's position, Grant contented himself with starving the Confederate forces in the city, while Union armies operating in other parts of Virginia further reduced Lee's ability to break out. Confederate forces did not despair however, and as an officer from North Carolina wrote, their resolve continued to strengthen: "I will fight them [the enemy] as long as I can crawl .... They may take every seaport town around the whole Southern Confederacy; they may overrun Virginia, [but] then we are not half whipped. We will fight them as long as there is a man [remaining] . . . For I had [rather] die as become a subject." ${ }^{, 72}$ In July, Union engineers detonated a mine under part of the Confederate siege lines, opening up a giant crater into which Union forces, including black soldiers, poured. Despite the initial shock of the explosion, Confederate forces reacted quickly and drove back the assaults, inflicting heavy casualties. Confederate forces also massacred black soldiers they found in the crater, helping to stain their combat record against troops their racist society believed unworthy to fight against white men of honor. ${ }^{73}$ The Overland Campaign represented a costly failure for the Army of Northern Virginia. At the outset of the campaign, Lee and his generals hoped to destroy Grant's army, or failing that, bleed it so badly that Grant had to withdraw. But Grant refused to let his climbing casualty rates dissuade him from his objective: the complete destruction of Lee's army as fighting force. Lee's aggressive attacks at the Wilderness could not break the Army of the 
Potomac, and his defensive victories at Spotsylvania and Cold Harbor did not slow the Union invasion. During the Overland Campaign, the Army of Northern Virginia could not achieve decisive results through aggression, but that did not stop its senior commanders from trying. Only the relentless aggression of Grant after the Battle of the Wilderness prevented Lee and his commanders from seizing the operational initiative that characterized their campaigns earlier in the war. ${ }^{74}$

$* * *$

A month and a half before Lee entered his siege lines at Petersburg, Confederate forces in the West began an offensive they hoped would lead to glory. Hood believed that tentative officers had no place in the Confederate high command. His service in the Army of Northern Virginia from 1861-1863 exposed him to the aggressive styles of Lee and Jackson, and he was determined to emulate their decisiveness. After the war, Hood laid out his beliefs on Johnston's failures, and on the benefits of aggressive action:

The troops of the Army of Tennessee had for such length of time been subjected to the ruinous policy pursued from Dalton to Atlanta . . . that they were unfitted for united action in pitched battle. They had, in other words, been so long habituated to security behind breastworks that they had become wedded to the 'timid defensive' policy, and naturally regarded with distrust a commander likely to initiate offensive operations .... [Lee's troops] were always taught to work out the best means to get at the enemy, in order to cripple or destroy him, in lieu of ever seeking the best means to get away from him. Therefore the Lee and Jackson school is the opposite of the Joe Johnston school, and will always elevate and inspirit, whilst the other will depress and paralyze. ${ }^{75}$

After assuming command of the Confederacy's largest army in the West, Hood attacked Sherman's forces at Peachtree Creek, and after finding no opening, withdrew and tried again against other Union forces outside Atlanta. Failing there, he recklessly 
attacked again at Ezra Church and Jonesborough. During the first phase of the Atlanta campaign, Johnston's forces lost roughly ten thousand soldiers, killed, wounded, or captured, trying to fend off Sherman over a two month period. Hood's recklessness cost the Army of Tennessee nearly fourteen thousand men in half that time. ${ }^{76}$ His aggression so drained his army that he had to abandon Atlanta to Sherman. Davis and the War Department had replaced a cautious commander with an aggressive commander, but the change did little to alter the result of the campaign. Unlike Johnston or even Bragg, however, Hood's actions earned him no censure because he followed the South's culturally accepted aggressive style of warfare. In fact, his soldiers gained confidence, and William Nugent from Mississippi wrote to his wife in 1864, "You may tell your friends that I say we are not near whipped; and the Yankees will find it out this spring ... one more grand fight in Georgia, after that we may expect nothing more than raids.,"77 Davis warned Hood in a meeting that he had considered replacing him, but ultimately Davis preferred that his generals fight aggressively rather than be defeated as the result of timid action. After the war, Davis continued to blame Johnston, wishing that he had acted sooner in replacing him with Hood:

[Johnston] failed to obey the positive orders to attack General Grant ... [if he] had vigorously attacked Sherman at Atlanta when directed, the fortunes of war would have been changed, and Sherman hurled back to Nashville, over a sterile and wasted country - his retreat little less disastrous than Napoleon's from Moscow. He did not do so, and was relieved - General Hood, a true and spirited soldier, taking his place - but the opportunity was then gone; and to this delay, more than any other cause, the Southern people will attribute their overthrow, whenever history comes to be truly written. ${ }^{78}$

The Confederate concern for honor and aggression shaped their war effort.

Disgrace only came to those not courageous enough to seize honor; those that tried, but failed still earned respect as gentlemen. So long as Confederate generals like Hood 
conducted battle along the lines demanded by southern honor, they retained command.

After his meeting with Hood in September 1864, Davis affirmed his belief that

Confederate armies would soon return to the North in a widely distributed propaganda

message:

General Hood's strategy has been good and his conduct has been gallant. His eye is now fixed upon a point far beyond that where he was assailed by the enemy. $\mathrm{He}$ hopes soon to have his hand upon Sherman's line of communications, and to fix it where he can hold it .... I believe it is in the power of the men of the Confederacy to plant our banners on the banks of the Ohio, where we shall say to the Yankee, "be quiet or we shall teach you another lesson. ${ }^{, 79}$

After conferring with Davis, Hood planned to move north into Tennessee, giving

Sherman the slip and concentrating his forces against the suddenly isolated George $\mathrm{H}$.

Thomas at Nashville. Hood reasoned that by moving north, he could tempt Sherman away from the unprotected heartland of the Confederacy in Alabama and Georgia. ${ }^{80}$

Hood had believed that he could carry out his campaign in secret because he had a strong numerical superiority in cavalry, including some of the best riders available to the Confederacy in September 1864. Outnumbering the Union cavalry by as much as two-toone, Hood's troopers were also significantly more experienced riders and fighters. However, Hood overestimated the importance of Sherman's supply lines. Believing that moving north would force Sherman to shadow him and protect his critically overstretched supply trains, Hood took with him almost the entire available pool of Confederate soldiers in the area. Instead of following, however, Sherman dispatched Thomas to deal with Hood, while Sherman gathered more than sixty thousand soldiers to march to the Atlantic seaboard, supplying his army from the previously untouched Confederate heartland. ${ }^{81}$ Hood's aggressive operation was seriously flawed in conception. Sherman now stood almost completely unopposed in his devastating campaign through the 
Confederate's unprotected southernmost states. The Confederate War Department could barely muster seven thousand soldiers to oppose Sherman, mostly poorly equipped militia too young or old to serve in the regular armies. ${ }^{82}$

Despite these obstacles, Hood set off toward Tennessee, from Palmetto, Georgia, with a force numbering close to forty thousand, almost the entire available operating force in the Confederate West. Using his experienced cavalry under Joseph Wheeler and Nathan Bedford Forrest to screen his movements while raiding Union supply wagons, tearing up railroad, and disrupting rearward positions, Hood maneuvered north. During the advance, Hood's forces captured a detachment of uniformed black Union soldiers, but rather than treat them as prisoners of war, the Confederates forced them to provide manual labor, tearing up Federal railroad tracks. Confederate officers like Hood, raised to see blacks as slaves, could not treat them in any other way. The racist antebellum plantation culture made it impossible for Confederate officers to accord the honors of war to men they believed property. Indeed, Hood sent most of the captured black soldiers back south to be returned to their former masters. ${ }^{83}$

Hood continued north, hoping to draw Sherman into Kentucky, or at the very least move east and help Robert E. Lee, pinned down at Petersburg by Grant. Meanwhile, Sherman simply ignored Hood, ordered Thomas to come south and engage Hood, and returned to Atlanta and his campaign against Savannah. P. G. T. Beauregard, advising Hood at Jefferson Davis's request, suggested that Hood abandon his movement north and strike Sherman before he could leave Atlanta. Though Beauregard's plan made military sense, Hood quickly abandoned it, believing that he could destroy Thomas's force quickly. Hood continued north, skirmishing with Union garrisons and Thomas's brigades 
that shadowed his march. By late November, Hood arrived outside the city of Franklin, Tennessee, but had been out-marched by Union forces under John M. Schofield in late November 1864. Schofield, commander of the Army of the Ohio, and responsible for pursuing Hood before linking with Thomas, used his time in Franklin wisely. Schofield ordered his army to create a series of redoubts, entrenchments, and defensive works to protect their lines because the city backed up to the Harpeth River, making withdrawal difficult. $^{84}$

Hood was aware of the strong Union defenses, but he nonetheless rushed most of his army at them. ${ }^{85}$ Hood's assault lacked tactical finesse, relying instead on courage and brute force. ${ }^{86}$ His failure to catch Schofield earlier in the campaign likely played a role in his decision to launch an all-out assault against heavily

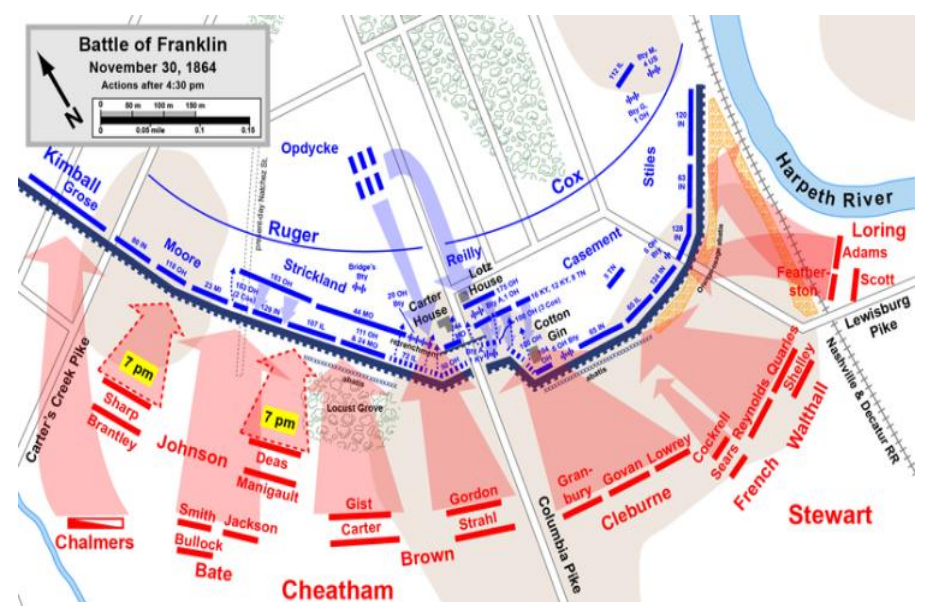

Illustration 3.1: Battle of Franklin fortified lines. The result was a predictable bloodbath. The Army of Tennessee reported more than six thousand casualties, including a stunning fourteen generals and fifty five regimental commanders, while Union forces barely lost a sixth of that number. ${ }^{87}$ Once again, the southern obsession with courage, aggression, and headlong attack decimated an army. Most striking, Hood's senior staff, whose aristocratic background and embrace of the South's militaristic honor culture encouraged their risky assaults, suffered an enormously high casualty rate. During the height of the attack, one of Hood's divisional 
commanders, William W. Loring, sensing his men's hesitation, shamed them forward, yelling, "Great Gods! Do I command cowards?" He proceeded to show himself to the Union lines, daring them to shoot him, while his soldiers rallied. ${ }^{88}$ Somehow avoiding injury, Loring moved the faltering brigade back into position, but they could not make any more headway. With the fighting concluded, and Hood unable to continue attacks because of darkness, Schofield withdrew in good order and linked with Thomas. Another aggressive Confederate assault failed, not because southern soldiers were unwilling to fight bravely, but because their commanders placed aggressive action above military reason.

Despite the terrible casualties his force suffered at Franklin, Hood continued to push north, hoping to bait Thomas into leaving Nashville. Knowing that their losses at Franklin had tempered his army's considerable enthusiasm to fight another offensive battle, Hood hoped he could tempt Thomas into attacking, and then follow with a counterattack strong enough to destroy Thomas and Schofield's forces. However, Thomas would not attack until he was certain he could destroy Hood's army. After a severe winter storm and written admonishments from Lincoln and Grant urging Thomas to attack, the Union general finally began the attack that Hood sought. ${ }^{89}$ However, Thomas's assault proved far more spirited than Hood believed possible. Over the course of the first day, Thomas gradually hammered Hood's lines inward, forcing the Confederates to create a more compact defensive line. On the second day, Union forces caved in Hood's sagging left flank, forcing the Confederates to retreat in the night. During the Battle of Nashville, Hood fought defensively, but his unwillingness to withdraw south after the disaster at Franklin sparked the battle. Hood believed his army 
could continue offensive operations, even though there was little they could do to damage the Union's position in Tennessee after the Battle of Franklin. That they even continued to campaign reveals the unwillingness of Confederate commanders to admit defeat when they still controlled armies in the field. Hood's inability to identify attainable military goals and pursue them instead of unrealistic dreams of northern conquest doomed his campaign from the start. Hood began the campaign with almost forty thousand men, but fewer than twenty thousand limped back to Confederate lines after the battles of Franklin and Nashville. ${ }^{90}$ Even by the sanguine standards of southern aggression, Hood's failures were too costly to ignore. Davis therefore stripped Hood of his command and gave what was left of his army to Johnston's forces, desperately trying to defend the Carolinas from Sherman's fast-moving invasion. ${ }^{91}$

The Franklin and Nashville campaigns largely ended coherent Confederate military operations in the western theatre because they destroyed the last major Confederate army operating in the area. More important, these operations highlight what could go wrong when commanders allowed cultural imperatives to outweigh military maxims. Commanders in the European tradition of warfare understood military truisms and followed them to the letter. Southern men like Hood, though well versed in the prevailing military wisdom of the time, could not temper their enthusiasm for battle with sound military decision making. During his time at West Point, Hood read the standard military texts of the time, including Antoine Henri-Jomini's The Art of War and his assertion that fortified lines should never be attacked frontally:

[To] return to the explanation of the measures most suitable for adoption in an attack on lines. If they have a sufficient relief to make it difficult to carry them by assault, and if on the other hand they may be outflanked or turned by strategic maneuvers, it is far better to pursue the course last indicated than to attempt a 
hazardous assault. If, however, there is any reason for preferring the attack by assault, it should be made upon one of the wings, because the center is the point most easily succored. ${ }^{92}$

Like Lee's decision on the third day of Gettysburg, Hood's actions at Franklin stand in stark contrast to Jomini's advice. Moreover, Hood did not represent an isolated case of poor generalship because Confederates made the same tactical mistakes across multiple campaigns. The battles of Shiloh, Seven Days, Stones River, Second Corinth, Antietam, Chancellorsville, Chickamauga, Gettysburg, and the Wilderness all fit the same tactical pattern, with the commanders at these battles constituting a who's who of important Confederate leaders. Despite the wealth of military training Confederate commanders brought to battle, they often ignored military dictums in their blind fervor to attack.

After Grant trapped Robert E. Lee and the Army of Northern Virginia in the siege lines of Petersburg, the Confederates had little chance to escape. With no help forthcoming from Confederate forces in the West and Grant continuing to tighten the Union grip around the city, Lee launched several breakout attempts. Following a Union attempt to storm the city in early April 1865, Lee finally abandoned his siege lines. Marching west to meet Johnston in the Carolinas, Lee was followed doggedly by Grant. McLaws noted the devastation of the countryside as they marched, but was impressed by the resolve of the population:

The South Carolinians have suffered very much . . . the rice planters who had surrounded themselves with every luxury and lived in lordly magnificence, upon their princely estates, have been left without lands or houses, or negroes and are wanderers. But they do not but in a few instances, appear to be downcast or repine over their fallen fortunes, but on the contrary are in high spirits and appear anxious to engage the enemy, in order to be revenged. ${ }^{93}$

Desperately outnumbered and with many of his men falling out of their marching columns for want of food and clothing, Lee still managed to attack Union forces at 
Amelia Springs before Union forces cut off portions of his army and forced them to surrender. ${ }^{94}$ Ever mindful of the deeply shameful consequences of surrendering without first exhausting all other options, Confederate forces continued to fight, hoping to stave off the inevitable. Even in the waning days of the war, Confederate forces continued to attack against impossible odds, motivated by a culture that would not allow them to surrender. One soldier in the Army of Northern Virginia wrote, "[soldiers] who suffer and have often suffered in this war are the last ones to say surrender. ${ }^{" 95}$ Indeed, Confederate forces rebuffed Union surrender overtures because Lee and his generals still hoped to escape to Johnston's forces and continue the war. ${ }^{96}$ Longstreet summarized the attitude of many of his fellow officers, who despite knowing they fought a lost cause, preferred to continue until they could fight no longer: "The cause was lost, but the end was not yet. The noble Army of Northern Virginia, once, twice conqueror of empire, must bite the dust before its formidable adversary." ${ }^{, 97}$ For southern men of honor, fighting to the death was preferable to surrender. A soldier named Fitzpatrick wrote that he had, "no distant dream of ever giving up .... Yankees may kill me but will never subjugate me." Fitzpatrick was mortally wounded on April 3, 1865, six days before the collapse of Lee's army. ${ }^{98}$ Grant finally caught up with Lee at Appomattox Court House and surrounded the tattered Confederate army. According to a staff officer, Lee's approach to the surrender negotiations was characteristically bleak: "When I bore the message back to General Lee, he said, 'Then there is nothing left me but to go and see General Grant, and I would rather die a thousand deaths." ${ }^{, 99}$ Surrender, long anathema to Confederate forces, finally became a reality for the Army of Northern Virginia. With breakout impossible, Lee surrendered the Confederacy's most important army. 
After years of unrelenting warfare, crowned by the casualties of hundreds of thousands of Confederate soldiers, what cultural impetus allowed Lee and his generals to surrender? They believed they could surrender honorably because they had exhausted all military recourses. The link between military action and honor meant that southern soldiers could face surrender only if convinced they could no longer forestall defeat through further force of arms. As Lee noted:

It is impossible to describe the anguish of the troops when it was known that the surrender of the army was inevitable. Of all their trials, this was the greatest and hardest to endure. There was no consciousness of shame; each heart could boast with honest pride that its duty had been done to the end, and that still unsullied remained its honour. ${ }^{100}$

Despite their surrender, southern soldiers could take solace in their defeat because they believed their honor remained intact, made so by their courage in battle and their sacrifices over the preceding years. During the war, the same honor culture that enabled them to attack repeatedly against overwhelming odds without demurring, now allowed them to surrender without losing face. The South's honor culture created a generation of Confederate officers dedicated to the attack, aggressive behavior, and feats of masculine bravery. Conversely, in the face of defeat and after years of combat, that same honor culture allowed the Confederate military to lay down its arms without the shame reserved for cowards. Under the South's honor code, surrender became an option once Confederate forces could no longer fight in an honorable fashion. The chance of victory realistically disappeared in 1863 , but Confederate forces continued the war for two more years because of the imperatives of the southern honor culture. As Lee said to General William Pendleton before the surrender, "We had, I was satisfied, sacred principles to maintain, and rights to defend, for which we were in duty bound to do our best, even if 
we perished in the endeavor." "101 The antebellum culture that drove them to fight so ferociously offered a way for southerners to believe their honor remained intact, even in defeat.

\section{****}

Over the past several decades, many military historians have turned to social science tools to examine their subjects. ${ }^{102}$ Traditional military history concentrated on generals, their campaigns, and the politics behind their actions, often ignoring cultural and social factors. This style of historical evaluation also dismissed the plight of the common soldier, essentially dismissing their impact in combat, and concentrating on campaign and battle summaries. In recent years, however, cultural history approaches have gained popularity and are often supplemented by quantitative analyses. ${ }^{103}$ Likewise, the battlefield influence of the South's honor culture can be discussed statistically, by examining casualty numbers, contemporary ratio calculations, and other numerical measures. Taken together, these numbers further illuminate the impact of southern honor on the Confederate military and its officer corps.

Determining how to evaluate honor, courage, and aggression statistically presents some challenges. The Union enjoyed significant manpower and economic advantages throughout the war. Confederate soldiers were often poorly equipped, outnumbered, and hungry, but they still performed well in battle. James B. Griffin wrote: "Our men don't complain — although they are without tents, and living pretty hard — and all they ask is to be in the fight." ${ }^{\prime 104}$ At the same time, Union soldiers compiled an impressive combat 
record, though often led by ineffective or cautious commanders. Over the course of the war the military competency of the North improved, rivaling that of the Confederacy's infantry and cavalry. Still, a statistical evaluation of the influence of southern honor culture produced on the battlefield is revealing.

After the Civil War, private citizens and public officials, hoping to determine the number of soldiers and casualties on each side, collected data from battle reports, hospital registers, and enlistment reports and produced several major works, often spanning thousands of pages. Confederate records remained notoriously incomplete, however, because of a paucity of recordkeeping during the war and the widespread destruction of the records during the chaotic final months of the war. ${ }^{105}$ Nevertheless, the compiled estimates of the United States War Department, based on southern muster rolls, indicate that about six hundred thousand soldiers served in the regular Confederate armies during the war. Of this estimate, 274,955 left the rolls through death, disease, desertion, or discharge, while 74,524 were killed in action or mortally wounded, a rate of 12.3 percent death in battle. ${ }^{106}$ In contrast, the Union casualty rate was 10.9 percent. ${ }^{107}$ Compared to battle deaths in the other nineteenth century western wars, these death rates were shockingly high. For example, in the Franco-Prussian War of 1870-1871, in which a coalition of German states led by Prussia soundly defeated France, the French suffered a battle casualty rate of less than 1 percent of their entire force. ${ }^{108}$

The hierarchical nature of southern society makes the war experiences of the officer class particularly revealing. Unfortunately, no unified count of the officer class for both armies exists. Instead, surveys often use samples of officers and extrapolate their experiences as exemplars of the whole. For example, Peter S. Carmichael's The Last 
Generation studies 121 elite young Virginian men who served as junior officers in the Confederacy's armies. But larger counts are available. By the end of the Civil War, 425 men had reached the rank of general in the Confederate Army, seventy three of whom were killed or mortally wounded in battle. ${ }^{109}$ In contrast, only forty five Union generals out of 583 suffered the same fate. ${ }^{110}$ A stunning 55 percent (235 of 425) of Confederate generals were killed or wounded at least once, while sixty four generals were wounded more than once, including three generals wounded at least five times. ${ }^{111}$ The higher Confederate death rates and raw numbers reveal the personal bravery and recklessness of southern officers on the battlefield, especially considering the far larger number of Union generals. In particular, Confederate officers placed themselves at the fore of most of their army's attacks, as witnessed by the fact that 70 percent of Confederate generals killed in action fell in offensive operations. ${ }^{112}$ Personal bravery, an important component of southern honor, almost certainly contributed to this casualty rate.

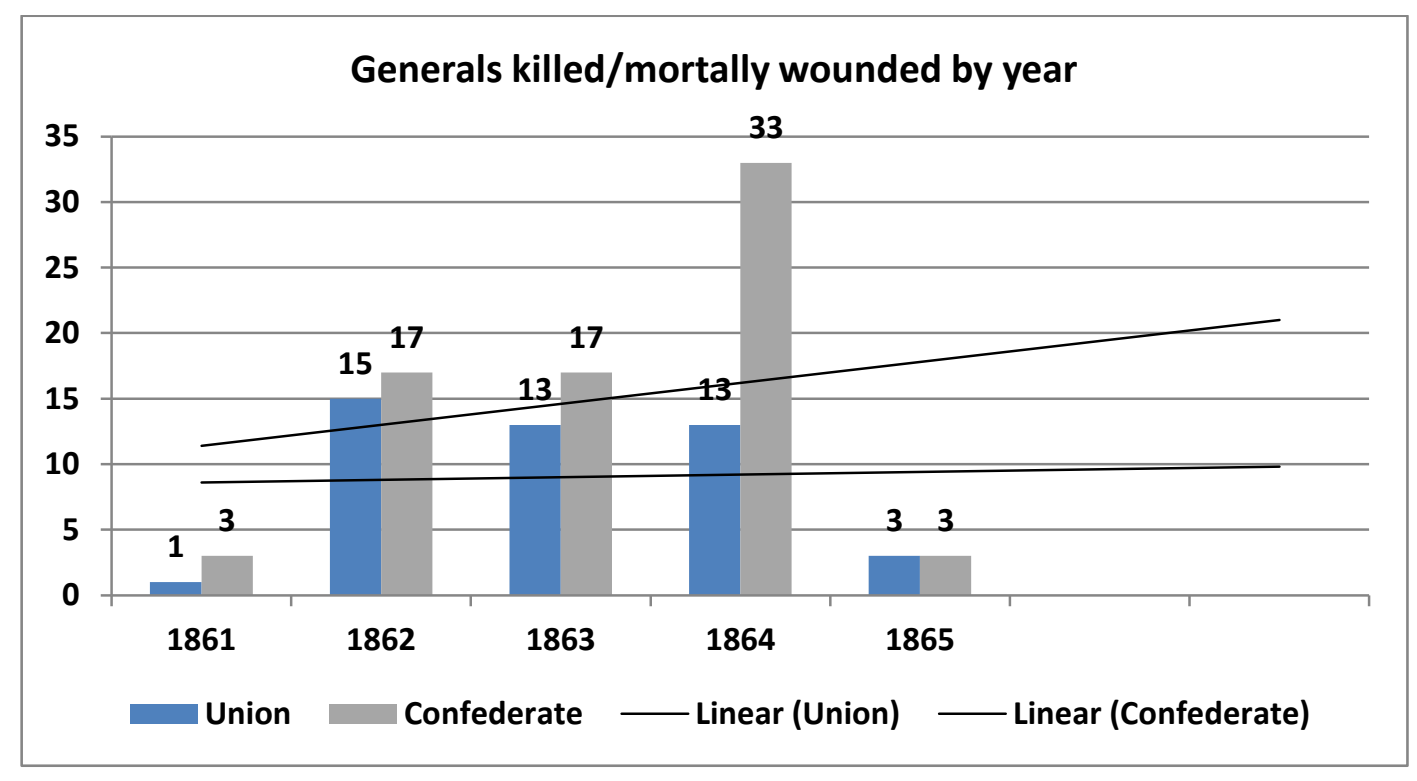

Illustration $3.2^{113}$ 
Equally revealing as the number of deaths among the Confederate generals is the question of when they died. Of the seventy three Confederate generals killed or mortally wounded in battle, thirty two were fatally wounded between the war's beginning and the battles of Gettysburg and Vicksburg; from July 3, 1863 to the end of the war, forty one lost their lives. ${ }^{114}$ More specifically, during the first thirty six months of the war thirty seven Confederate generals were killed or mortally wounded in battle, while during the last thirteen months thirty six Confederate generals were killed or fatally wounded. ${ }^{115}$ Why did the killed in action rate of Confederate generals spike in the last thirteen months of the war? While the pattern of Confederate generals' deaths in battle may be coincidental, a comparison to the number of Union generals killed in battle makes this conclusion unlikely. The Confederacy commissioned 425 generals compared to the 583 the Union appointed. Of these, at least seventy three Confederate generals were killed or mortally wounded in battle (17 percent) compared to only forty four Union generals (7.5 percent). ${ }^{116}$ Moreover, unlike the growth in the numbers of Confederates killed over this time, Union generals' battle deaths remained more evenly distributed. By year, the Union lost one, fifteen, thirteen, thirteen, and three generals in battle. ${ }^{117}$ These numbers point to a cultural explanation for Confederate deaths and highlight the high rate of mortality among the South's officer corps, especially among its most elite members.

As the prospects for Confederate victory diminished, and the losses piled up, Confederate generals sought a conclusion to the war that ended either with a miraculous victory or at least guaranteed an honorable defeat. Southerners' belief that defeat was acceptable only when the South could no longer go on fighting emanated from the region's conceptions of personal honor. The prospects of defeat shamed Lee and his 
fellow generals, but once they began to accept it as a likely outcome, they looked for terms that would not impugn their personal honor or the honor of their armies. The data suggests that southern gentlemen often concluded that death in battle represented the most honorable way out of the war. As Confederate war hero Thomas "Stonewall" Jackson wrote: "What is life without honor? Degradation is worse than death."118 Griffin echoed Jackson's words in a letter to his family: “And if it is God's will that I shall fall, I hope to fall at the head of my men and leave the Legacy, to my Dear Dear very Dear family, that I died the most glorious and honorable death known to man — That of fighting for Liberty." 119

Personal sacrifice, so important in the southern elite's chivalric codes, placed a great deal of emphasis on fighting heroically in defense of one's family. ${ }^{120}$ As the war demanded a growing commitment to realize an ever-diminishing chance of success, the number of officer casualties climbed. In short, the number of Confederate generals killed in the last thirteen months of the war grew because of officers' willingness to sacrifice for the cause and reverse the downward spiral of the Confederate military fortunes. Whether they deliberately put themselves in harm's way is difficult to determine, but considering the South's cultural attachment to bravery, its marked distaste for surrender, fatalistic Christian notions of the virtuous warrior, and the dire straits of a failing Confederate war effort, the growth in the number of dead Confederate generals as the war came to a close seems unsurprising. Still, southern cultural paradigms differed from other fatalistic military ethoses, like the bushido code of Japanese forces in World War II, which made death in battle the price of defeat. ${ }^{121}$ Instead, Confederate officers, desperately trying to stave off defeat, led their armies from increasingly vulnerable positions and suffered 
devastating casualties because their society praised their sacrificial heroism. Hood noted a conversation between himself and Jackson, which highlights how Confederate officers conceptualized the inevitability of their death or maiming in battle:

We were riding together in the direction of General Lee's headquarters, [and] the conversation turned upon the future, and [Jackson] asked me if I expected to live to see the end of the war. I replied that I did not know, but was inclined to think I would survive; at the same time, I considered it most likely I would be badly shattered before the termination of the struggle. I naturally addressed him the same question, and, without hesitation, he answered that he did not expect to live through to the close of the contest. Moreover, that he could not say that he desired to do so. ${ }^{122}$

Confederate officers as a group, and not simply the men of the high command, paid a high price for their society's attachment to honor. Leading from the front lines, expected from men who placed a high premium on personal courage, inevitably led to high casualty rates among the officer corps. Over the course of the war, the Army of Northern Virginia suffered an astonishingly high casualty rate among its officer corps, with four of every five either killed outright or wounded at least once. ${ }^{123}$ A quarter of all southern officers fell in battle, and officers were twice as likely to be killed in action as the enlisted men who served under them. ${ }^{124}$ In his seminal work on the Army of Northern Virginia, historian Joseph Glatthaar examines Confederate officer casualty rates during Seven Pines, Seven Days, Second Bull Run, Antietam, the Valley Campaign, Cedar Mountain, and South Mountain. He finds the killed in action rates of Union officers 20 percent lower and their wounded rates 10 percent lower than their Confederate counterparts. ${ }^{125}$ Glatthaar's sample of six hundred Confederate officers and enlisted men returns even more shocking numbers. Roughly one in every four officers was killed in battle, and half of all officers were killed or wounded at least once. ${ }^{126}$ In a larger sample, Bruce S. Allardice examines the lives of 1,583 Confederate colonels, and found that 16 
percent were killed in battle, comparable to the sample of 425 Confederate generals, further confirming the sample's statistical weight. ${ }^{127}$ Furthermore, the sample of colonels' deaths follows the same pattern as the generals', with casualties spiking at the end of the war.

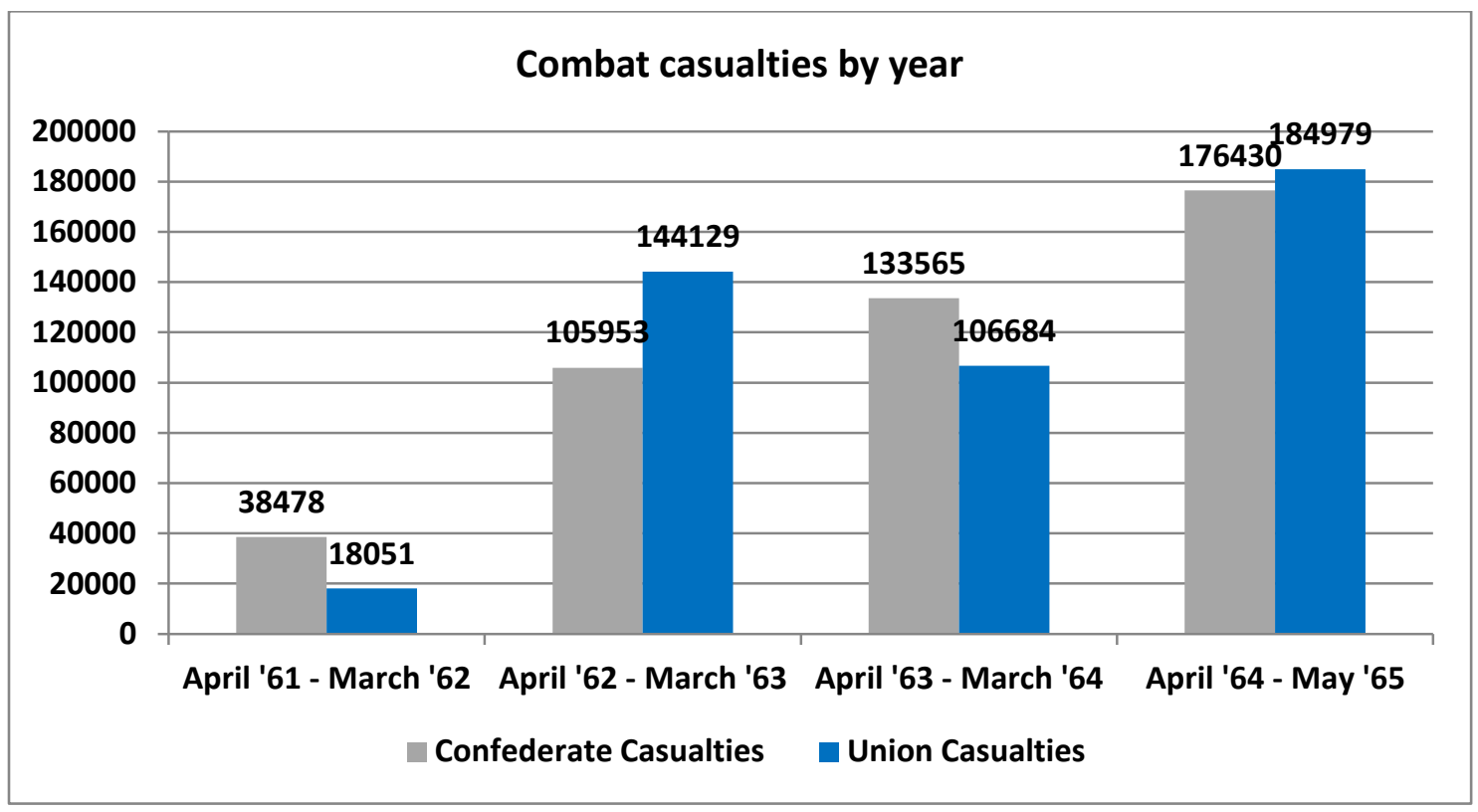

Table $3.3^{128}$

Did the casualty rate of Confederate enlisted men look similar to their officers? The table above further dispels the notion that Confederate commanders changed their tactics as the number of men they had available shrunk. ${ }^{129}$ In the same way that Confederate generals continued to hazard their lives, if not purposefully put themselves at greater risk, casualties among Confederate enlisted men suffered through the same spike in numbers. This indicates one of two things: that Confederate commanders, seeking death or glory, exposed their armies to even greater perils as the war went on, or that Confederate enlisted soldiers shared the same feelings about their ever decreasing chances of total victory. Still, both answers indicate a fatalistic approach to the end of the 
war that made death in battle a preferable outcome. As one Confederate soldier wrote in 1865:

"I am in favor of prosecuting [this war] to the last extremity. For if we do not gain our independence, I cannot see anything but [my own] slavery staring me in the face, and ... I would rather die .... I am not willing to be driven back [-] until the last man of us has perished."130

Both explanations also point to a demonstrable rise in Confederate forces exposing themselves to sustained combat in an effort to gain victories. The data supports this assertion, especially when compared to Union casualties, which did not rise consistently throughout the war. However, the raw casualty data reveals a fascinating dichotomy when viewed alongside the numbers of Confederate soldiers captured during the war. While it seems logical to expect Confederate battle deaths to mirror the number of soldiers captured, the data instead suggests success in battle correlated significantly with the capture of Confederate soldiers.

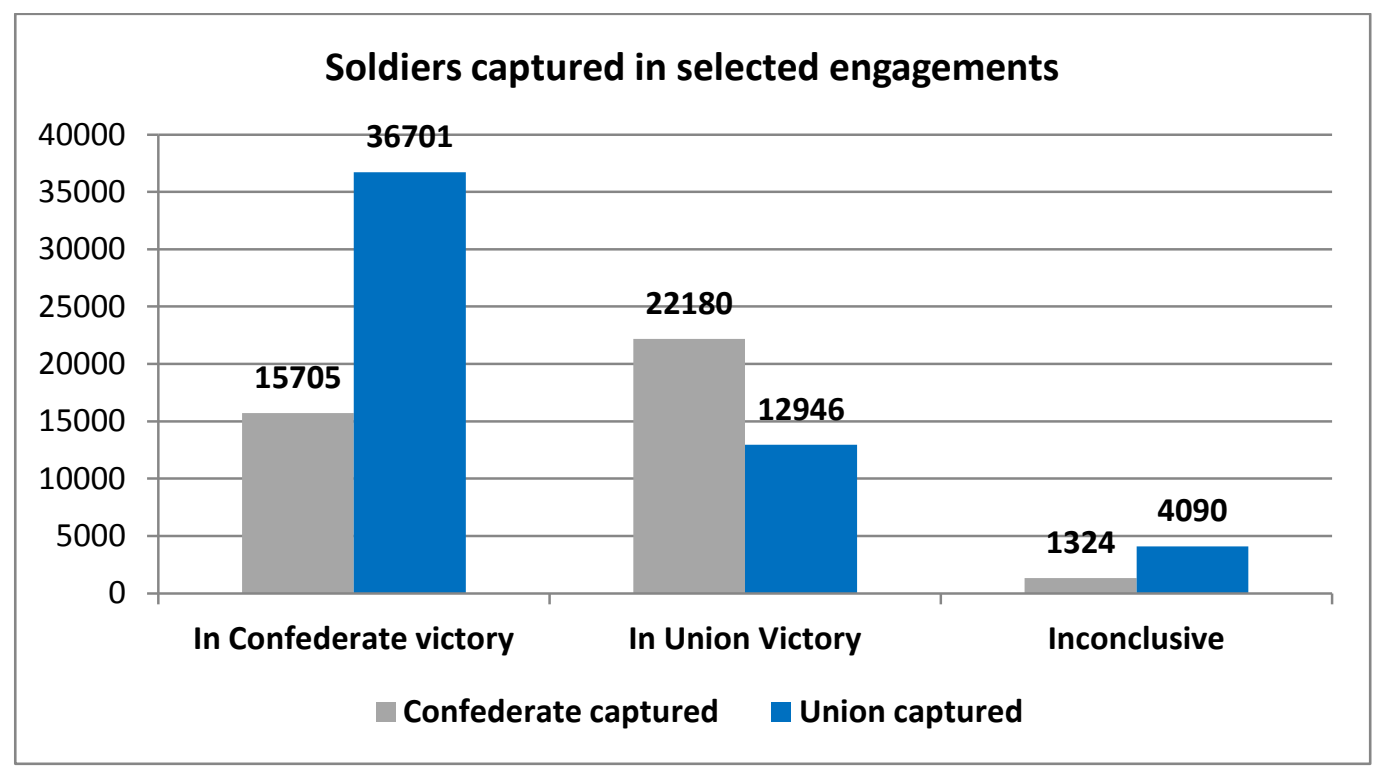

Table $3.4^{131}$

Culled from a sample of the war's twenty eight battles with at least one thousand casualties on both sides, this table records the total number of soldiers captured in these 
battles. The battles represent fifteen Confederate tactical victories, ten tactical Union victories, and two inconclusive engagements. ${ }^{132}$ Immediately noticeable is the discrepancy between the numbers of soldiers captured in victories rather than defeats. Military theory would argue that soldiers are more likely to be captured in defeat than in victory, and this dictum lines up perfectly with the data on Union soldiers captured in these battles; nearly 70 percent of Union soldiers captured surrendered in battles in which they were tactically defeated. However, the opposite is true of Confederate soldiers, where the number of their soldiers captured in defeat is only slightly more than half. Confederate soldiers captured in battle were 15 percent more likely to be taken during a victory than their Union adversaries. ${ }^{133}$

Why did the rate of Confederate soldiers captured climb in victories in comparison to Union soldiers? Confederate generals were often disinclined to call off attacks that had already met objectives or carried the field. At Seven Days, Chancellorsville, Chickamauga, and the Wilderness, Confederate officers continued to lead attacks even after securing the field, routing portions of Union lines, or meeting objectives. Their behavior follows the southern cultural paradigm that praised courage and aggressive behavior. Commanders found it difficult to rein in troops who moved too far ahead and hesitated to stop attacks that were succeeding. Withdrawal or hesitation result in public accusations of cowardice. With their masculinity and bravery at stake, Confederate commanders and soldiers kept attacking beyond what made military sense to gain a decisive victory. They more often initiated battles, continued to attack once battle was joined, and lost far more men in victory their Union foes. For example, in the thirteen battles in which Confederate forces lost at least one thousand men captured 
included in the table above, they were the aggressors in ten of the battles. In short, the southern honor culture increased the likelihood that Confederate soldiers would continue to attack beyond military necessity, thereby increasing the likelihood they would advance too far and fall into Union hands. The data suggests this was particularly true in Confederate triumphs, where victorious southern soldiers pursued defeated Union forces too quickly and became victims of their own success.

Officer resignation rates offer another marker of a commander's personal investment and perhaps sense of duty, by showing the likelihood officers would resign their commission and return to civilian life or non-combat duty. Here, the difference between Union and Confederate generals is even more pronounced. One hundred ten Union generals resigned their commands during the war, compared to only nineteen of their Confederate counterparts. ${ }^{134}$ Only one Confederate general was cashiered out of the service during the war, while three Union generals faced dismissal. ${ }^{135}$ Union generals who failed spectacularly faced significant inquiry from the Federal War Department, which weeded out insubordinate or incompetent commanders. Conversely, the Confederates considered defeat an honorable outcome of battle as long as they conducted themselves bravely. Consequently, officers resigned at far lower rates, despite failure in battle. This may have enabled incompetent commanders who should have been cashiered to keep their jobs. John Bell Hood's performance at Franklin should have cost him his command, but his superiors allowed him retain it, resulting in the crushing defeat at Nashville. Even with the relative paucity of experienced commanders late in the war, Davis passed over several generals more qualified to lead the Army of Tennessee than Hood, including James Longstreet. 
Confederate commanders who displayed personal bravery demanded the same from their units, resulting in high casualty rates. However, dividing casualties by enlistment totals paints an incomplete picture, and does not reflect the character of the individual southern soldier. In Attack and Die, historians Grady McWhiney and Perry D. Jamieson use the war's raw casualty data to argue that Confederate aggression severely damaged fighting capabilities and wasted manpower reserves. ${ }^{136}$ Using mathematical equations to examine variables such as topography, chance of success, combat experience, and other battle-specific data help paint a fuller picture. Exchange ratios, for example, depict the losses sustained by a military suffering an attritional war, as the Confederacy did in its final months. Civil War force ratio equations, in contrast, identify an army's ability to inflict casualties, by dividing an opponent's casualties by the size of the enemy's army. ${ }^{137}$ The higher the force ratio achieved, the more successful an army was at inflicting casualties on its opponent. Scholar Herbert K. Weiss examines force ratios and concludes that Confederate forces were more effective at inflicting casualties than their Union opponents. ${ }^{138}$ Employing three principal sources — Frederick Phisterer, Statistical Record, Thomas L. Livermore, Numbers and Losses in the Civil War, and Gaston Bodart, Kriegs-Lexikon - Weiss demonstrates the consistent ability of Confederate forces to perform effectively in battle despite their numerical deficiencies. ${ }^{139}$ Phisterer details 2,261 separate engagements in the war, while Livermore describes sixtyfour battles resulting in at least one thousand Union casualties.

Weiss rejects McWhiney and Jamieson's blanket descriptions of southern military wastefulness. Based on force ratio analysis, Weiss examines the entire Civil War and concludes that Confederate forces, with a 15.5 percent force ratio, inflicted casualties 
more effectively than the Union, whose force ratio was 11.5 percent. ${ }^{140}$ The numbers suggest southerners were better able to inflict casualties and therefore more effective in battle than their Union opponents. More important, Confederates performed well in offensive battles and attacking fortified lines. Southern cultural values often prevented Confederate armies from disengaging or hesitating before attacking entrenched lines that might have slowed or stopped less aggressive commanders. Weiss's calculations also show that defenders clearly had an advantage in attacking fortified lines. An examination of Union and Confederate attacks on fortified lines reveals how each side fared as offensive and defensive entities. Table 3.5, focusing on battles with the highest losses per one thousand and at least five thousand soldiers on both sides, reveals that Confederates consistently achieved higher force ratios.

\begin{tabular}{|c|c|c|c|}
\hline \multicolumn{4}{|c|}{ Table of select battles and force ratios } \\
\hline \multicolumn{2}{|c|}{ Union losses per 1000 (Force ratio \%) } & \multicolumn{2}{|c|}{ Confederate losses per 1000 (Force ratio \%) } \\
\hline Victories & Defeats/Failures & Victories & Defeats/Failures \\
\hline Stones River 223 (24) & $\begin{array}{l}\text { Port Hudson, June } 14267 \\
\text { (1) }\end{array}$ & Chickamauga 259 (24) & Gettysburg 301 (35) \\
\hline Gettysburg 212 (33) & Olustee 265 (17) & Chancellorsville 187 (28) & Stones River $266(37 \%)$ \\
\hline Shiloh 162 (17) & Cedar Mountain 219 (17) & $\begin{array}{c}\text { Bull Run/Chantilly } 187 \\
\text { (36) }\end{array}$ & Shiloh 241 (33) \\
\hline Antietam 155 (18) & Fort Wagner 214 (11) & Olustee $180(37)$ & Atlanta, July 28222 (4) \\
\hline Cedar Creek 132 (9) & Chickamauga 196 (31) & Drewry's Bluff 158 (23) & Franklin 206 (12) \\
\hline Winchester $124(10)$ & Wilson's Creek 175 (22) & Gaines’s Mill 153 (12) & Tulepo 201 (7) \\
\hline Fair Oaks 105 (14) & Drewry's Bluff 175 (8) & Wilson's Creek 100 (12) & Perryville 196 (26) \\
\hline Pea Ridge 105 (8) & $\begin{array}{c}\text { Port Hudson, May } 27141 \\
\text { (2) }\end{array}$ & Fort Wagner 95(84) & Atlanta, July 22190 (9) \\
\hline Corinth 104 (18) & The Mine 138 (10) & Cedar Mountain 79 (14) & Fair Oaks 137 (12) \\
\hline Perryville $100(6)$ & $\begin{array}{c}\text { Bull Run/Chantilly } 132 \\
\text { (13) }\end{array}$ & Pleasant Hill 70 (11) & Peachtree Creek 133 (9) \\
\hline $\begin{array}{c}\text { Non-weighted average: } \\
142\end{array}$ & Non-weighted average: 192 & Non-weighted average: 146 & $\begin{array}{l}\text { Non-weighted average: } \\
209\end{array}$ \\
\hline $\begin{array}{c}\text { Average force ratio: } \\
15.7 \%\end{array}$ & Average force ratio: $13.2 \%$ & Average force ratio: $28.1 \%$ & Average force ratio: $18.4 \%$ \\
\hline Total force ratio: $18 \%$ & Total force ratio: $16.4 \%$ & Total force ratio: $24 \%$ & Total force ratio: $22.2 \%$ \\
\hline
\end{tabular}

Table $3.5^{141}$ 
Table 3.5 reveals the high Confederate casualty rates in failed assaults, but it also demonstrates high Confederate force ratios. Confederate armies achieved higher total force ratios and higher average force ratios than their Union counterparts, often gaining battlefield successes independent of force size. Despite being outnumbered, Confederate forces were often more potent statistically on the attack than their Union opponents. In victory, the average Confederate soldier inflicted 12.4 percent more casualties than Union soldiers, and in defeat, 5.2 percent. $^{142}$

This data can also be used to examine battle success by battle size. The highlighted battles represent engagements that included at least forty thousand men on the battlefield. The two columns with the most highlighted battles are Union victories and Confederate defeats, demonstrating that despite impressive individual per-man performances, Confederate defeats in major battles doomed their long term goals. Of the sixteen individual battles highlighted, Confederate forces were the primary aggressors in twelve. Confederate forces also took the offensive in seven of the war's nine costliest battles. Fox's Regimental Losses records seventy Confederate regiments that suffered at least 50 percent casualties in a single engagement. ${ }^{143}$ In contrast, during the entire Franco-Prussian War, only two regiments suffered a single battle casualty rate above 46 percent. ${ }^{144}$ Military historians often conclude that high casualty rates in single battles indicates defeat, an incompetent general, or a reckless assault. But thirty three (47 percent) of the regimental losses listed by Fox occurred in Confederate tactical victories. These numbers indicate the Confederate proclivity to over-expose units to prolonged action, a disregard for individual losses, and collective bravery among the rank and file. The highest single battle percentage loss of the war belonged to Hood's $1^{\text {st }}$ Texas 
regiment at Antietam at 82.3 percent. ${ }^{145}$ Without an incredibly strong social stigma denigrating cowardice and promoting bravery, Confederate soldiers would not have made these sorts of sacrifices. The southern honor culture pervaded Confederate units and enabled them to sustain incredibly high unit losses in pursuit of victory. The honor culture influenced both the officer corps and the enlisted men. Even though the South's lower class conceptualized honor differently than their social betters, it still pushed them to attack and die with little hesitation. The incredible casualty rate of the Confederacy's enlisted men testifies to their bravery as well as the aggression of their commanders. Taken together, they help explain the incredibly high losses the Confederacy both suffered and inflicted.

The end of the Civil War represented a cataclysmic humbling of the South's people and the culture that guided their actions. Hundreds of thousands of soldiers and civilians died or were wounded, the region's slave population gained its freedom, and the South's economy collapsed. A war to protect slavery and the right of states to secede to protect that institution began with a confidence endemic to the South's prewar elite. Southern men, believing in their superiority as soldiers, statesmen, and warriors, thought their defeat impossible. During the war, the Confederate military conducted itself as an extension of the culture that created it. Confederate commanders recognized their place in the European military tradition, but they remained more concerned with their role as southern men of honor. From the first shot at Fort Sumter, Confederate commanders carried out the war without compromising the values of the plantation society from which they sprang. The white South's emphasis on aggression, courage, masculinity, disdain for cowardice, and the protection of the community propelled Confederate battlefield 
strategy. The South's planter class, the region's antebellum political, social, and economic elite, took up arms to defend what they perceived as the North's attack on their culture. The relative homogeneity of the Confederate officer corps ensured that the values they lived by before the war helped guide them on the battlefield. As a result, they adopted aggressive tactics throughout the war, only partially abandoning them when the losses became too great to bear. Only when the Confederate military lost the ability to conduct the war aggressively, did southern men believe they could surrender honorably. The South's honor culture guided the Confederate populace both in its fight for independence and in its decision to put down arms and return to the Union.

${ }^{1}$ William Faulkner, The Sound and the Fury (New York: The Modern Library, 1929), 76. ${ }^{2}$ Sword, Southern Invincibility, 153.

${ }^{3}$ Lynn, Battle, 126-27, 181.

${ }^{4}$ Black, Western Warfare 1775-1882, 165.

${ }^{5}$ Duffy, Military Experience in the Age of Reason, 35.

${ }^{6}$ Ibid., 35.

${ }_{8}^{7}$ Lynn, Battle, 115.

${ }^{8}$ Ibid., 130-32.

${ }^{9}$ Ibid., 123.

${ }^{10}$ Wyatt-Brown, Southern Honor, 418-19.

${ }^{11}$ Lorien Foote, The Gentlemen and the Roughs: Manhood, Honor, and Violence in the Union Army (New York: New York University Press, 2010), 3.

${ }^{12}$ Ibid., 3.

${ }^{13}$ Ibid., 3.

${ }^{14}$ Keegan, The American Civil War, 222.

${ }^{15}$ Catton, The Civil War, 198.

${ }^{16}$ Keegan, The American Civil War, 201, 219.

${ }^{17}$ Sword, Southern Invincibility, 194; Leckie, None Died in Vain, 583.

${ }^{18}$ Phillips, Diehard Rebels, 98.

19 "We must wait and see what developments time will make, perhaps the rain now falling is our special benefit, may be for the enemy perhaps something may turn up in Europe for our benefit, France may recognize us and give active assistance. There may be a political revolution at the North, which will be of some assistance - General Lee may best the enemy in Virginia, or we may damage him here very seriously. There is always grounds for hope, and there are so many instances of good fortune coming to us, when we have no reason to expect any, that the motto should ever be, 'Never despair!' so be of good cheer and write often." Longstreet, From Manassas to Appomattox, 207. 
${ }^{20}$ Sword, Southern Invincibility, 145.

${ }^{21}$ Longstreet, From Manassas to Appomattox, 331.

22 Ibid., 524-25.

${ }^{23}$ Earl J. Hess, The Civil War in the West: Victory and Defeat from the Appalachians to the Mississippi (Chapel Hill: University of North Carolina Press, 2012), 195.

${ }^{24}$ Phillips, Diehard Rebels, 95.

${ }^{25}$ Keegan, The American Civil War, 222.

${ }^{26}$ Sword, Southern Invincibility, 195.

${ }^{27}$ Keegan, The American Civil War, 223-24.

${ }^{28}$ Sword, Southern Invincibility, 214.

${ }^{29}$ Glenn Tucker, Chickamauga: Bloody Battle in the West (Dayton, OH: Morningside Bookshop, 1976), 357.

${ }^{30}$ Shelby Foote, The Civil War, a Narrative: Fredericksburg to Meridian (New York: Vintage Books, 1986), 759.

${ }^{31}$ For further reading on the Battle of Chickamauga, see Glenn Tucker, Chickamauga: Bloody Battle in the West (Dayton, OH: Morningside Bookshop, 1976); Peter Cozzens, This Terrible Sound: The Battle of Chickamauga (Urbana, IL: University of Illinois Press, 1992); and Steven E. Woodworth, Six Armies in Tennessee: The Chickamauga and Chattanooga Campaigns (Lincoln: University of Nebraska Press, 1998).

${ }^{32}$ Foote, The Civil War, a Narrative: Fredericksburg to Meridian, 762-63.

${ }^{33}$ Hess, The Civil War in the West, 198.

${ }^{34}$ McWhiney and Jamieson, Attack and Die, 160.

${ }^{35}$ Catton, The Civil War, 185.

${ }^{36}$ Sword, Southern Invincibility, 227.

${ }^{37}$ Ibid., 227.

${ }^{38}$ Archer Jones, Civil War Command and Strategy: The Process of Victory and Defeat (New York: Free Press, 1992), 188.

${ }^{39}$ Sword, Southern Invincibility, 227.

${ }^{40}$ Catton, The Civil War, 190.

${ }^{41}$ Leckie, None Died in Vain, 605-606.

${ }^{42}$ Stephen M. Hood, John Bell Hood: The Rise, Fall, and Resurrection of a Confederate General (El Dorado Hills, CA: Savas Beatie L. L. C., 2013), 23.

${ }^{43}$ Leckie, None Died in Vain, 607.

${ }^{44}$ McWhiney and Jamieson, Attack and Die, 161.

${ }^{45}$ Craig L. Symonds, Joseph E. Johnston: A Civil War Biography (New York: W.W. Norton \& Company, Inc., 1992), 324.

${ }^{46}$ Wiley Sword, The Confederacy's Last Hurrah: Spring Hill, Franklin, and Nashville (Lawrence: University Press of Kansas, 1993), 32.

${ }^{47}$ Mary Chesnut, Diary of Mary Chesnut (Fairfax, VA: D. Appleton and Company, 1905), 230.

${ }^{48}$ Sword, Southern Invincibility, 248.

${ }^{49}$ Leckie, None Died in Vain, 606.

${ }^{50}$ Keegan, The American Civil War, 236.

${ }^{51}$ Ibid., 235. 
${ }^{52}$ Anthony Saunders, Trench Warfare 1850-1950 (Barnsley: Pen \& Sword Military, 2010), 60 .

${ }^{53}$ Longstreet, From Manassas to Appomattox, 551.

${ }_{55}^{54}$ McWhiney and Jamieson, Attack and Die, 164.

${ }^{55}$ Longstreet, From Manassas to Appomattox, 435.

${ }^{56}$ McWhiney and Jamieson, Attack and Die, 165.

${ }^{57}$ Catton, The Civil War, 193.

${ }^{58}$ Ibid., 195.

${ }^{59}$ Leckie, None Died in Vain, 588.

${ }^{60}$ Phillips, Diehard Rebels, 99.

${ }^{61}$ Catton, The Civil War, 195.

${ }^{62}$ Saunders, Trench Warfare 1850-1950, 58-59. The first major battle in which Confederates dug entrenchments in preparation for fighting was at Mine Run in November 1863.

${ }^{63}$ McWhiney and Jamieson, Attack and Die, 109

${ }^{64}$ Longstreet, From Manassas to Appomattox, 113.

${ }^{65}$ Sword, Southern Invincibility, 195.

${ }^{66}$ Leckie, None Died in Vain, 586-87.

${ }^{67}$ Catton, The Civil War, 197.

${ }^{68}$ Keegan, The American Civil War, 243-44.

${ }^{69}$ Leckie, None Died in Vain, 592.

${ }^{70}$ Keegan, The American Civil War, 247-48.

${ }^{71}$ McPherson, Battle Cry of Freedom, 735.

${ }^{72}$ Sword, Southern Invincibility, 152-53.

${ }_{74}^{73}$ McPherson, Battle Cry of Freedom, 760.

${ }^{74}$ For further reading on the Overland Campaign, see Gary Gallagher, The Wilderness Campaign (Chapel Hill: University of North Carolina Press, 2006); Alfred C. Young III, Lee's Army During the Overland Campaign: A Numerical Study (Baton Rouge:

Louisiana University Press, 2013); and Earl J. Hess, Trench Warfare under Grant and

Lee: Field Fortifications in the Overland Campaign (Chapel Hill: University of North Carolina Press, 2007).

${ }_{76}^{75}$ McWhiney and Jamieson, Attack and Die, 109.

${ }^{77}$ Keegan, The American Civil War, 265-67.

${ }^{77}$ Phillips, Diehard Rebels, 96.

${ }^{78}$ McWhiney and Jamieson, Attack and Die, 167.

${ }^{79}$ Sword, The Confederacy's Last Hurrah, 51-52.

${ }^{80}$ Leckie, None Died in Vain, 621.

${ }^{81}$ Ibid., 620.

${ }^{82}$ Keegan, The American Civil War, 273.

${ }^{83}$ Sword, The Confederacy's Last Hurrah, 56-57.

${ }^{84}$ Foote, The Civil War, a Narrative: Red River to Appomattox, 664.

${ }^{85}$ Catton, The Civil War, 239.

${ }^{86}$ Map of the Battle of Franklin of the American Civil War, showing the Union defensive lines at 4:30 PM. Drawn in Adobe Illustrator CS5 by Hal Jespersen.

http://www.posix.com/CWmaps/ 
${ }^{87}$ Foote, The Civil War, a Narrative: Red River to Appomattox, 672.

${ }^{88}$ Sword, The Confederacy's Last Hurrah, 216-18, 226-27.

${ }^{89}$ Keegan, The American Civil War, 277.

90 Ibid., 277.

${ }^{91}$ For further reading on the Atlanta, Franklin, and Nashville Campaigns, see James R.

Knight, The Battle of Franklin: When the Devil Had Full Possession of the Earth

(Charleston, SC: The History Press, 2009); Gary Ecelbarger, The Day Dixie Died: the

Battle of Atlanta (New York: Thomas Dunne Books, 2010); Albert A. Castel, Decision in

the West: the Atlanta Campaign of 1864 (Topeka: University of Kansas Press, 1992); and Wiley Sword, The Confederacy's Last Hurrah.

${ }^{92}$ Antoine Henri de Jomini, The Art of War (Mechanicsburg, PA: Stackpole Books, 1854), 214.

${ }^{93}$ McLaws, A Soldier's General, 252.

${ }^{94}$ Foote, The Civil War, a Narrative: Red River to Appomattox, 909-910.

${ }^{95}$ Phillips, Diehard Rebels, 85.

${ }^{96}$ Keegan, The American Civil War, 347.

${ }^{97}$ Longstreet, From Manassas to Appomattox, 603.

${ }^{98}$ Phillips, Diehard Rebels, 89.

${ }^{99}$ Longstreet, From Manassas to Appomattox, 624.

${ }^{100}$ A. L. Long, Memoirs of Robert E. Lee: His Military and Personal History (New York:

J. M. Stoddart \& Company, 1887), 423.

${ }_{101}$ Longstreet, From Manassas to Appomattox, 621.

${ }^{102}$ Lynn, Battle, xv-xvii.

${ }^{103}$ John Keegan, The Face of Battle: A Study of Agincourt, Waterloo, and the Somme (New York: Penguin Group, 1978) and John A. Lynn, Battle, are two of the most important books to integrate culture and military theory.

${ }^{104}$ McArthur, A Gentleman and an Officer, 199.

105 J. David Hacker's article "A Census-Based Count of the Civil War Dead" has raised doubts about the validity of Civil War casualty statistics. By examining prewar and postwar census totals, Hacker believes that previous counts of the dead may be as much as one hundred thousand to two hundred thousand men short. Even though his work has been received well by scholars, it does not shed light on the casualties of individual battles, and therefore does not have any bearing on this section of the thesis.

${ }^{106}$ Livermore, Numbers and Losses in the Civil War in America, 4-5.

${ }^{107}$ Herbert K. Weiss. "Combat Models and Historical Data: The U.S. Civil War" Operations Research. Vol. 14, No. 5 (Sep-Oct, 1996) 759-90.

${ }^{108}$ Matthew White, "Statistics of Wars, Oppressions and Atrocities of the Nineteenth Century (the 1800s)." last modified March 2011. Accessed October 16, 2013. http://necrometrics.com/wars19c.htm

${ }^{109}$ Fox, Regimental Losses in the American Civil War, 1861-1865, 571-73.

${ }^{110}$ Ibid., 40-41.

${ }^{111}$ McWhiney and Jamieson, Attack and Die, 15.

112 Ibid., 15.

${ }^{113}$ Fox, Regimental Losses in the American Civil War, 1861-1865, 40-41, 571-73. 
${ }^{114}$ Numbers culled from tables in Fox, Regimental losses in the American Civil War, 1861-1865.

${ }^{115}$ Numbers culled from tables in Fox, Regimental Losses in the American Civil War, 1861-1865.

${ }^{116}$ E. B. Long, The Civil War Day by Day: An Almanac 1861-1865 (New York: Da Capo Press, 1971), 713. In Generals in Gray: Lives of Confederate Commanders (Baton Rouge: Louisiana State University Press, 1959), Ezra J. Warner lists seventy seven Confederate generals killed in action. The discrepancy is accounted for by including generals brevetted before battle from the rank of colonel.

${ }^{117}$ Fox, Regimental Losses in the American Civil War, 1861-1865, 40-41.

${ }^{118}$ Foote, The Civil War, a Narrative: Fort Sumter to Perryville, 65.

${ }^{119}$ McArthur, A Gentleman and an Officer, 229.

${ }^{120}$ Wyatt-Brown, Southern Honor, 26.

${ }^{121}$ Lynn, Battle, 247. Bushido is a Japanese word meaning "way of the samurai" and is roughly analogous to medieval Europe's knightly code of chivalry. During World War II, most Japanese soldiers, following the precepts of bushido, refused to surrender, preferring death in battle to dishonorable surrender. Defeated Japanese soldiers also routinely took their own lives rather than face disgrace. The southern honor code, in contrast, allowed Confederate soldiers to surrender with honor, assuming that they fought bravely.

${ }^{122}$ Stephens, Commanding the Storm, 109-110.

${ }^{123}$ Glatthaar, General Lee's Army, 198.

${ }^{124}$ Ibid., 198.

${ }^{125}$ Ibid., 198.

${ }^{126}$ Glatthaar, Soldiering in the Army of Northern Virginia, 94.

${ }^{127}$ Bruce S Allardice, Confederate Colonels: A Biographical Register (Columbia:

University of Missouri Press, 2008), 15.

${ }_{128}^{128}$ Fox, Regimental Losses in the American Civil War, 1861-1865, 540-51.

${ }^{129}$ Darroch Greer. "Counting Civil War Casualties, Week-By-Week, Article for the Abraham Lincoln Presidential Library and Museum," Abraham Lincoln Presidential Library and Museum, 2005, 47.

http://www.brcweb.com/alplm/BRC_Counting_Casualties.pdf

${ }^{130}$ Sword, Southern Invincibility, 190.

${ }^{131}$ Tables culled from Fox's, Regimental Losses in the American Civil War, 1861-1865.

${ }^{132}$ Confederate victories: First Bull Run, Wilson's Creek, Seven Pines, Seven Days, Cedar Mountain, Second Bull Run, Chaplin Hills, Fredericksburg, Chancellorsville, Chickamauga, Second Petersburg, Crater, Wilderness, Spotsylvania, Cold Harbor. Union victories: Shiloh, Corinth, Gettysburg, Chattanooga/Missionary Ridge, Opequon, Cedar Creek, Franklin, Nashville, Bentonville, Fort Stedman. Inconclusive: Williamsburg, Stones River.

${ }^{133}$ Percent of total Confederate captured in victory (41 percent) subtracted by percent of total Union captured in victory (26 percent).

${ }^{134}$ Jayne E. Blair, The Essential Civil War: A Handbook to the Battles, Armies, Navies and Commanders (Jefferson, NC: McFarland \& Company, Inc., 2006), 38.

${ }^{135}$ Ibid., 38. 
${ }^{136}$ McWhiney and Jamieson, Attack and Die, 7.

${ }^{137}$ For example, in the Civil War the equation to determine a single battle's force ratio would be: Union casualties divided by Confederate army size. This number is then compared to Confederate casualties divided by Union army size. The higher ratio determines which army more effectively inflicted casualties on its opponent during the engagement. Force ratios seek to determine which side inflicted casualties at a higher rate, independent of force size. Weiss uses these calculations to compare Union and Confederate forces in battle. The Lanchester-Type (another ratio measurement of battlefield effectiveness) force models have multiple components, but the most basic, and the model used in this paper, is the force ratio.

${ }^{138}$ Weiss, "Combat Models and Historical Data: The U.S. Civil War," 787.

${ }^{139}$ Ibid., 761. Frederick K. Phisterer, Statistical Record (New York: Charles Scribner's Sons, 1883); Thomas L. Livermore, Numbers and Losses in the Civil War (Bloomington: Indiana University Press, 1957); and Gaston Bodart, Kriegs-Lexikon (Wien \& Leipzig, 1908).

${ }^{140}$ Weiss, "Combat Models and Historical Data: The U.S. Civil War," 766-67.

${ }^{141}$ The table was created from reports in The Essential Civil War, 62-222, Livermore's Numbers and Losses, and Phisterer's Statistical Record. The non-weighted average and the force ratio calculations do not appear in any of the books, and were compiled by the author. The numbers in the columns were calculated by the formulas laid out in endnote 135. The non-weighted averages examine the number of soldiers lost per 1000 in the battles in the table. The averages (\%) indicate force ratios, both raw totals and averaged. 142 These numbers are calculated in two equations. For victories: subtract the average force ratio of Union victories (15.7) from the average force ratio of Confederate victories (28.1) which equals 12.4. For defeats: subtract the average force ratio of Union defeats (13.2) from the average force ratios of Confederate defeats (18.4) which equals 5.2. In both victory and defeat, Confederate forces inflicted casualties at a higher rate.

${ }^{143}$ Fox, Regimental Losses in the American Civil War, 1861-1865, 556-57.

144 Ibid., 37.

145 Ibid., 556. 


\section{EPILOGUE: RECONSTRUCTION, RADICALS, AND RECIDIVISM}

The collapse of the Confederate States of America's military in 1865 broke the will of the South's populace to continue serious organized resistance. After four long and bloody years of war, the Confederacy was trampled under the victorious advance of Union armies. In terms of material damage to the South and its white population, the Civil War represented a complete upheaval. Hundreds of thousands of Confederate soldiers were battle casualties and more than a quarter of southern white men of military age died during the war from battle, disease, and in Union prisons. ${ }^{1}$ Some 57 percent of the Confederacy's counties witnessed enemy action, a number that accounted for 63 percent of the Confederacy's free population. ${ }^{2}$ A war to protect slavery, preserve honor, and secede from the Union failed, and a majority of the white population felt that defeat personally, whether they witnessed it scar their land or lost loved ones in the fighting. As William Faulkner wrote in 1951, "the past is never dead. It's not even past."3 Despite their defeat in the Civil War and the changes that loss meant for the region, white southerners determined to retain the racial, economic, and social hegemony they enjoyed before the war. In the wake of their military defeat, white southerners turned to new mediums of discourse for southern honor, southern militarism, and southern identity. Even after the humbling of their armies during the Civil War, the South's white elite believed in their superiority and looked for ways to vindicate their honor. Prominent southern publisher H. Rives Pollard wrote in 1866: "The South can yet preserve its moral and intellectual distinctiveness as a people, and continue to assert its well-known 
superiority over the North in civilization, and political scholarship, in its schools of refinement and in all standards of individual character. This superiority the war has not conquered or lowered, and the South will do right to claim and cherish it." ${ }^{, 4}$ Far from stamping out the honor culture of the South, the Civil War helped infuse new life into it, albeit in ways different from the violence of the battlefield.

The South's white populace felt deep shame as a result of their wartime failures. In the minds of militant southerners, the Civil War should have vindicated long held beliefs about their military and cultural superiority over their northern neighbors. For several decades before the outbreak of hostilities, many white southerners viewed civil conflict as an eventuality that if not welcome, would be easily won. The possibility of defeat did not enter their deepest nightmares. At the end of the Civil War, white southerners once so sure of their superiority had to face a new era publicly humbled and with the very foundations of their society shaken. The South's slaveocracy, which had long dictated the region's national posture felt particularly humiliated. The Emancipation Proclamation, announced during the war, and the Thirteenth Amendment, adopted in 1865 , forever outlawed slavery and destroyed the foundations of prewar southern society. ${ }^{5}$ Ratified by most of the southern states after the war in order to gain readmission to the Union, the Thirteenth Amendment represented the end of the South's slave society.

Yet during the postwar process of rebuilding the South known as Reconstruction, the white elite stubbornly refused to recognize their defeat. Rejecting the calls of northern Republicans to enforce severe penalties on their defeated region, southern Democrats fought back. Even though the federal government barred many former Confederates from public office and thousands of senior Confederate soldiers and public servants had to take 
loyalty oaths because of their role in the rebellion, they still vehemently opposed Reconstruction, often through illegal means. ${ }^{6}$ Some former Confederate leaders found remaining in the conquered South too humiliating and chose exile in foreign nations instead. ${ }^{7}$ Though never numbering more than a few thousand, the exodus of exConfederates illustrated the unwillingness of many white southerners to cooperate with northern Reconstruction. ${ }^{8}$

Alongside President Abraham Lincoln's stated purpose of returning the southern states to the Union, northern Republicans demanded a change in black-white relations in the South. But racist white southerners refused to relinquish their place in the social hierarchy of the South. They viewed recognizing their former slaves as social equals as tantamount to a complete destruction of the southern way of life. Instead, white southerners fought back in several ways. Legally, southern legislatures worked to gut measures to enfranchise blacks, help provide former slaves with the means to leave their plantations, and begin the process of introducing widespread literacy to the southern black community. In addition, southern whites resisted what they saw as intrusions by northern whites, whom they derisively labeled carpetbaggers, and federal agencies, particularly the Freedmen's Bureau, that attempted to lift up the newly freed black population. $^{9}$

White southerners also believed that northerners economically exploited the extreme poverty of the South. The legal end of slavery crippled the southern plantation system. Widespread war devastation and rampant inflation left many southern landowners destitute and the value of southern property fell to less than half of its pre1860 worth. ${ }^{10}$ Pervasive poverty among the former white southern elite created 
opportunities for northerners with liquid assets who came to the region, acquired plantations at low prices, purchased control of business interests, and inserted themselves into the local political structure through money and alliances with the partially mobilized southern blacks. ${ }^{11}$ As a result, both groups earned the enmity of the southern white elite, now pushed from their former place of economic and social preeminence in the South. The end of slavery automatically forced a partial collapse of the South's plantation system, fundamentally changing the nature of the region's agrarian economy. The average size of plantations fell by half between 1860 and 1880, but the devastation wrought to southern farmland during the war opened new avenues of economic growth, especially smaller sharecropping farms. ${ }^{12}$ Northern businessmen used the opportunity to open the region to new industry, especially railroads, and helped finance the construction of thousands of miles of track. ${ }^{13}$ Northerners and northern capital dominated the shift to a more modern and diverse economy, further alienating southerners from a rebuilding process that despite its benefits they did not initially control. Even though these northern efforts benefited the region, southern whites refused to cooperate with northerners or the newly enfranchised African American population. To combat these groups, southern whites turned to an illegal means of redress with which they had great familiarity before and during the war: violence.

On April 14, 1865, five days after the surrender of the Army of Northern Virginia, John Wilkes Booth stepped into the President Lincoln's box at Ford's Theatre and shot him. By some accounts, Booth yelled either, "The South is avenged," or "Sic semper tyrannus," meaning "Thus always to tyrants," in Latin. ${ }^{14}$ The Lincoln assassination sent shockwaves through the North and South, and raised new questions about how Congress 
would approach Reconstruction. Before his death, Lincoln's policy had embraced a consistently moderate approach to readmitting the defeated South to the Union. ${ }^{15} \mathrm{He}$ understood the anger the war's bloodletting had caused in the North, but sought to balance the desire for vengeance against the need to reform the nation peacefully and quickly. His magnanimity and willingness to include the South in the process of reunion was correspondingly diminished in Republican leadership in the years that followed his assassination. Without his steadying hand, the less moderate elements of the Republican Party had a stronger platform to challenge the tone of Reconstruction. ${ }^{16}$ President Andrew Johnson, a southern sympathizer, clashed with the Republican majority, essentially supporting the elements of southern society determined to erase their defeat.

Republicans seized control of both the House of Representatives and the Senate and enacted legislation, often over the veto of Johnson. ${ }^{17}$ They sought to lengthen Reconstruction and make the South pay for the war, force changes in the treatment of southern blacks, and stamp out the racist southern culture that had caused the war in the first place. ${ }^{18}$ In the words of Pennsylvania Congressman Thaddeus Stevens, Reconstruction must "revolutionize Southern institutions, habits, and manners .... The foundations of their institutions ... must be broken up and relaid, or all our blood and treasure have been spent in vain."19 The southern elite instead sought immediate admittance to the Union, a quick return of their voting privileges, and a restoration of their political equality. A speedy Reconstruction would have rewarded the South for seceding because the slave population, which previously counted as three-fifths of the total population for the purpose of congressional representation, would now as freemen be counted as equals. The southern states stood to gain congressional representation and 
political power through their defeat. ${ }^{20}$ Republicans rightly opposed such an outcome and before readmitting the former rebel states, sought serious concessions and changes. But the southern states were unwilling to make changes to their society, even in the face of a northern military occupation.

The assassination of Lincoln, though certainly the most well-known act of southern postwar violence, was hardly the last. ${ }^{21}$ Many southern whites, regardless of social and economic class, rejected the policies of Republicans and mounted resistance, often violent, against the party's perceived proxies — northerners in the South, free blacks, and southern whites sympathetic to the Republican cause, known as scalawags. ${ }^{22}$ As publisher H. Rives Pollard explained, "We shall strike hard blows for the people and against their oppressors, whether they be native enemies or imported tyrants." 23 The presence of a sizable number of discharged Confederate veterans helped spawn dozens of paramilitary groups that terrorized the perceived "enemies" of the southern Democratic cause. They murdered and terrorized African Americans, engaged in widespread voter suppression, and intimidated northern businessmen and their allies whenever they could. ${ }^{24}$ The largest of these paramilitary organizations, the Klu Klux Klan, counted many high ranking ex-Confederate generals such as George Gordon and Nathan Bedford Forrest as early members. ${ }^{25}$ Even Federal forces occupying the South struggled to protect populations targeted by the Klan, though Ulysses Grant managed to suppress it in some states during his presidency. As the South's violent resistance stiffened, many southern whites looked increasingly at the Civil War as a shameful blot on their regional memory. Determined to erase their failure, white southerners began a highly successful effort to distort the realities of the war and restore their honor. 
To explain their military defeat and rationalize the end of their slavery-based culture, the white southern elite turned to mythmaking. The myths, collectively known as "the Lost Cause of the Confederacy," involved two separate accounts of the Civil War. The first, fact-based account of the war, described what actually happened. In contrast, the southern interpretation of events, people, and battles willfully distorted the memory of the Civil War during the postwar era. This misrepresentation reflected several flawed assumptions about the South's participation in the war and the region's ability to conduct it successfully. The Lost Cause represented a deliberate attempt to explain away the defeat of the Confederacy by shifting the blame from the military competency of the officer corps as a group toward other factors. ${ }^{26}$ The Lost Cause myth originated in the postwar writings of Confederate officers, helping to explain its militaristic focus. In short, the Lost Cause was a cultural and literary movement through which the southern elite attempted to escape culpability for the war, vindicate their behavior, keep their honor intact, and explain their military failures by blaming factors beyond their control.

The Lost Cause movement originated with a series of articles written by one of Robert E. Lee's former lieutenant generals, Jubal Early. Like many of his fellow Lost Cause writers, Early argued that the Confederacy had not lost because of the military skill of the United States but as a result of its overwhelming numbers. ${ }^{27}$ In their view, the Confederacy lasted for four years only because of the military abilities of its generals, specifically Lee and Thomas "Stonewall" Jackson. In the highly Christian South, the two titans of the Army of Northern Virginia acquired saintly qualities, transforming their military exploits into extended hagiographies. ${ }^{28}$ The work of Early and his fellow Lost Cause writers deeply influenced southern opinion after the Confederacy's defeat, their 
authority arising from their positions during the war. Men like Early, who served in the Army of Northern Virginia, played an instrumental role in creating the cult of Lee and Jackson. The primacy of the eastern theatre, which quickly became a central tenet of Lost Cause writers, developed because of men like Early who served there and believed that front the most important of the war. As their writing gained increasing credence, the importance of the western theatre correspondingly diminished. As a result, mainstream American culture began to accept the primacy of the eastern theatre, and gradually myth passed into fact. ${ }^{29}$ The acceptance of the Lost Cause by much of the white South eventually grew beyond simple arguments about the relative importance of Confederate armies. A series of ideologically driven dogmas began to develop as southern memory. Most important, the Confederate elite argued that defeat was both simultaneously inevitable because of Union advantages and somehow also winnable due to the skill of Confederate generals. ${ }^{30}$ The fact that these two arguments were mutually exclusive proved immaterial to Confederate mythmakers. On one hand, they argued that Union armies, much larger, better supplied, and more numerous, made southern resistance noble but ultimately futile. ${ }^{31}$ However, they also argued that the exploits of Confederate generals like Lee and Jackson nearly won the war. In their opinion, the Battle of Gettysburg, and Pickett's Charge in particular, represented the "high tide" of the Confederacy geographically into Union territory and in terms of its chances of victory. The triumph slipped from their grasp, not because Lee destroyed part of his force in an unsuccessful attack into the teeth of the Union army, but because they had been betrayed from within, by too cautious or incompetent elements of the military. 
The enshrining of Lee and Jackson required that their battle records be scrubbed clean of defeat. Southern writers simply ignored Lee's initial failures in 1861 and his subsequent demotion. ${ }^{32}$ Likewise, they downplayed Jackson's poor showing during the Seven Days campaign, and instead both men's other victories became evidence of their impressive combat records. ${ }^{33}$ According to Lost Cause proponents, Jackson's death at Chancellorsville robbed the Confederacy of one of its greatest defenders, and had he lived the outcome of the war would have somehow changed. The whitewashing of specific beloved commanders' military records also required identifying a group of officers to blame for defeat. Chief among them was one of Lee's corps commanders, James Longstreet. Despite Lee's affection for Longstreet, and Longstreet's own strong combat record, many Lost Cause writers vilified Lee's "Old Warhorse." 34 In particular, they pointed to his failures on the second day of Gettysburg as evidence of his ineptitude. However, Lost Cause writers more likely targeted Longstreet because of his close relationship after the war with Republican President Ulysses Grant and his support for Republican Reconstruction in the South. ${ }^{35}$ Another focus of contention centered on the lost orders during the Maryland campaign, and recriminations swirled for years after the war as generals blamed one another in an effort to escape culpability. ${ }^{36}$

Elite southerners also looked to the prewar period as part of the reimagining of their role in the Civil War. Antebellum whites embraced the concept of paternalism, which argued that African Americans benefited from their enslavement because they were a backward, less evolved people. ${ }^{37}$ As Confederate Senator Benjamin Hill wrote in 1865 , "Slavery is the only civilizer of the negro." 38 Southern slaveholders believed they brought the light of Christian humanitarianism to their enslaved people, and this 
understanding helped them justify race-based slavery. By arguing for paternalism, antebellum slaveholders painted a fictitious portrait of happy slaves basking in their master's strong but ultimately beneficial control. This southern white memory of slavery ignored the endemic and frighteningly casual brutality, frequent escape attempts, and unrelenting fear of slave revolt that characterized the antebellum period. ${ }^{39}$ After the war, former slaveholders and southern apologists continued to argue that their slaveocracy benefited African Americans, and that the institution of slavery would have died out naturally without northern hostility. ${ }^{40}$ Unsurprisingly, the fact that hundreds of thousands of former slaves bore arms or assisted Union armies in the fight against the Confederate escaped mention by southern writers. ${ }^{41}$ Their argument that slavery would die naturally contrasted sharply with prewar southern efforts to further entrench slavery where it already existed and spread it to new territory in the American West. In short, after the war white southerners continued to misrepresent the conditions and goals of slavery. They persisted in creating myths about the origin and nature of the war, but the foundations of their arguments rested on outright falsifications.

Alongside their paternalistic arguments, postwar southerners explicitly stated that the hostility of northern abolitionists caused the war. ${ }^{42}$ According to white southerners, their region's cultural aggression had nothing to do with the increasingly hostile antebellum sectional rhetoric. A significant feature of the Lost Cause consisted of whitewashing the South's culpability in starting the war or even laying the groundwork for its outbreak. Southern writers argued that the North forced the war upon them, and that they would have happily left the Union without fighting. Their argument implied that all states possessed the legal right to secede and that leaving the Union did not constitute grounds 
for the use of force by Federal troops. Even ignoring the constitutional and legal ramifications of this argument, southerners essentially discounted their role in igniting the war at Fort Sumter. They even attempted to change public perceptions of the war through its name. Referring to it variously as the War Between the States, the War of the Rebellion, the War of Northern Aggression, the War for Southern Independence, or the Freedom War absolved the South of culpability or explicitly blamed the North. ${ }^{43}$ Despite the political and economic undertones of the southern propaganda campaign, the central goal of the Lost Cause writers remained the restoration of southern honor, something that required white-washing the Confederacy's military performance. The failure of the Confederacy to achieve its independence through war, despite their belief in their military superiority, represented a blow to the region's pride and distinct culture. Rooted in confrontation, the honor culture of the South demanded that gentleman who sought honor be victorious in any contest. The South's decision to go to war represented a region-wide acceptance of confrontation with the North. Defeat, especially when southerners believed they would enjoy an easy victory, crushed the region's selfimportant conceptions. ${ }^{44}$ An honorable fight made defeat acceptable, but it remained a blemish on the reputation of the southern white elite. To erase this stain southern writers essentially rewrote the history of the war. In an era when the white elite was losing control of the South's economy, politics, and society, the assault on history offered them a comfortable refuge. They could still satisfy their honor by reimagining the war. In particular, they found the assertion that northern resources made the war unwinnable extremely reassuring. Believing that their resistance was noble, but doomed from the outset, made southern whites better able to rationalize defeat. In their mind, they were not 
beaten, but simply overwhelmed by the sheer numbers, money, and military resources of the North.

Such beliefs also allowed white southerners to continue to discuss their military superiority and the stellar combat records of their leading generals, while dismissing Union generals, even successful ones, as products of the North's industrial might. For example, southerners pointed to Grant's bloody Overland Campaign as evidence that he was a butcher rather than a general, while ignoring his campaign against Vicksburg which represented some of the most skilled maneuvering of the war by either side. ${ }^{45}$ But Lost Cause proponents never concerned themselves with facts. The southern writers who created the myth believed in the justness of their cause and the truth of their assertions, but doing so required distorting the history of the war. The Lost Cause ignored historical facts because white southerners found such memories easier to accept than the alternative. Such myths absolved white southerners of culpability and allowed them to regain the honor they had lost in defeat.

Several major tenets of the Lost Cause continue to echo in modern America. ${ }^{46}$ Historians have argued that even though the North won the Civil War, the South won the fight for the war's memory by convincing themselves that they had not been defeated. ${ }^{47}$ After the war, northerners struggled to reconcile themselves to the great losses they suffered in pursuit of holding the Union together. With abolition complete, the North lost one of its greatest cultural unifiers in the decade before the Civil War. Westward expansion and significant economic opportunities also facilitated a redistribution of the North's populace. While the white South found vocal ways to assuage their battered cultural psyche, northerners became intensely introspective. Without serious northern 
opposition to the voluminous southern Lost Cause writers, the South effectively rewrote the history of the war. Even in modern America, many of the main beliefs of the Lost Cause still find ready acceptance. ${ }^{48}$ The Lost Cause effectively reduced the war to an incorrect caricature, depicting the North as a rapacious behemoth that ruthlessly suppressed a noble, justified, and prostrate South. ${ }^{49}$ Despite their military defeat, the South effectively dictated the nation's memory of the Civil War.

Before the Civil War, the white elite of the South dominated the economy, politics, and social system of the region. The honor culture that guided their actions rested on a series of belief structures deeply influenced by their own sense of superiority. Honor, pride, courage, and masculinity dominated the social interactions of white southerners, who were acutely aware of their place in the region's social hierarchy. The white elite created a racist society that dominated and exploited its subservient black slave population for profit and power. When the Civil War broke out between the southern slave states and the free North, the South's elite readily accepted their roles as the Confederacy's military leadership. The honor culture's violence, aggression, and militarism provided a strong basis for military participation throughout the South. The Confederacy fought for four years, but ultimately was defeated. The same culture that allowed southerners to fight so fiercely also allowed the region to lay down its arms in honorable defeat. However, white southerners remained deeply shamed by their defeat and almost immediately after the war turned to myth-making to explain their loss. Despite the devastation and destruction wrought by the Civil War, the South's white elite stubbornly clung to their sense of superiority. Before, during, and after the war, the 
southern honor culture defined the white elite, and helps explain their actions on and off the battlefield.

The Confederate Lost Cause enabled the white South to recover emotionally after its defeat in the Civil War. More important, it provided a point of resistance for white southerners in their fight against Reconstruction and its proponents. The Lost Cause stiffened southern attachments to the honor culture and it created a way for white southerners to take pride in their region, even in defeat. Sadly, the Lost Cause effectively reinforced the violent, insular, and racist identifiers of the antebellum South during the postwar period. It substituted antebellum paternalism and hatred of abolitionists for postwar hatred of Republicans, northern businessmen, freemen, and southerners who cooperated with the northern-led state governments. After 1865, southern whites took renewed pride in their cultural values as they sought to regain political and economic control of their region from northern domination. By the end of Reconstruction, southern resistance largely erased the gains of free African Americans, the federal government, and northerners in the region. In 1877, after several years of increased anti-black violence, voter intimidation, and election fraud, white southerners gained control of the state governments of Louisiana, Florida, and South Carolina, effectively returning white control to the South. ${ }^{50}$ The northern public, weary of the sectional conflict, let the South return to its antebellum conservatism and racism. Southern elites, humbled by their military defeat, essentially rewrote the history of the war to restore a measure of pride to their battered honor. They paid a heavy price, however, as the Lost Cause guaranteed that the South remained chained to the racism and classism of the antebellum period. Over the next several decades the rest of the nation moved forward economically and culturally 
while the South stagnated. But within a few years of the end of Reconstruction, white southerners could look back on the Civil War with pride, recalling the nobility of their defiance, the dignity of their defeat, and the immaculate condition of their honor. The South fabricated a new past from the ashes of their defeat, one about which they could proudly boast.

${ }^{1}$ James M. McPherson, Abraham Lincoln and the Second American Revolution (New York: Oxford University Press, 1992), 38.

${ }^{2}$ Paul F. Paskoff, "Measures of War: A Quantitative Examination of the Civil War's Destructiveness in the Confederacy." Civil War History, 54 Num. 1, (March 2008), 3562, 41. These calculations exclude Texas and Florida because they witnessed comparatively little of the war and had the Confederacy's smallest populations. If they are included, then 36 percent of Confederate counties and 54 percent of the population witnessed the war.

${ }^{3}$ William Faulkner, Requiem for a Nun (New York: Random House, 1951), 92.

${ }^{4}$ Rubin, A Shattered Nation, 192-93.

${ }^{5}$ Donna L. Dickerson, The Reconstruction Era: Primary Documents on Events from 1865 to 1877 (Westport, CT: Greenwood Press, 2003), 16.

${ }^{6}$ John Hope Franklin, Reconstruction after the Civil War, $2^{\text {nd }}$ Edition. (Chicago: University of Chicago Press, 1994), 15.

${ }^{7}$ See James L. Roark, Masters Without Slaves: Southern Planters in the Civil War and Reconstruction (New York: Norton, 1977).

${ }^{8}$ Rollin G. Osterweis, The Myth of the Lost Cause, 1865-1900 (Hamden, CT: Archon Books, 1973), 8.

${ }^{9}$ Franklin, Reconstruction after the Civil War, 93.

${ }^{10}$ J. G. Randall and David Hebert Donald, The Civil War and Reconstruction. $2^{\text {nd }}$ edition (Lexington, MA: D. C. Heath and Company, 1969), 547.

${ }^{11}$ Franklin, Reconstruction after the Civil War, 94.

${ }^{12}$ Randall and Donald, The Civil War and Reconstruction, 549.

13 Ibid., 547.

${ }^{14}$ James Swanson, Manhunt: The 12-Day Chase for Lincoln's Killer (New York:

William Morrow Paperbacks, 2007), 48.

${ }^{15}$ Franklin, Reconstruction after the Civil War, 16-17.

${ }^{16}$ For further reading on the complexities of the Reconstruction Era, see Eric Foner, Reconstruction: America's Unfinished Revolution, 1863-1877 (New York: Harper \& Row, 1988).

${ }^{17}$ Franklin, Reconstruction after the Civil War, 61.

${ }^{18}$ Dickerson, The Reconstruction Era, 16-17.

${ }^{19}$ McPherson, Abraham Lincoln and the Second American Revolution, 6.

${ }^{20}$ Richard M. Valelly, The Two Reconstructions: The Struggle for Black

Enfranchisement. (Chicago: University of Chicago Press, 2004), 29. 
${ }^{21}$ See George C. Rable, But There Was No Peace: The Role of Violence in the Politics of Reconstruction (Athens: University of Georgia Press, 1984).

${ }^{22}$ Franklin, Reconstruction after the Civil War, 98.

${ }^{23}$ Rubin, A Shattered Nation, 193.

${ }^{24}$ Osterweis, The Myth of the Lost Cause, 12.

${ }^{25}$ Dickerson, The Reconstruction Era, 251.

${ }^{26}$ Gary W. Gallagher and Alan T. Nolan, eds., The Myth of the Lost Cause and Civil War History. (Bloomington: University of Indiana Press, 2010), 14-15.

${ }^{27}$ Ibid., 22.

${ }^{28}$ Thomas L. Connelly and Barbara L. Bellows, God and General Longstreet: The Lost Cause and the Southern Mind (Baton Rouge: Louisiana State University Press, 1982), 29.

${ }^{29}$ For further reading on Jubal Early and his role in the Lost Cause see, Gary W. Gallagher, Jubal A. Early, the Lost Cause, and Civil War History: A Persistent Legacy (Milwaukee, WI: Marquette University Press, 1995).

${ }^{30}$ Gallagher and Nolan, eds., The Myth of the Lost Cause and Civil War History, 22-24.

${ }^{31}$ Ibid., 40-41.

${ }_{33}^{32}$ Connelly and Bellows, God and General Longstreet, 27.

${ }^{33}$ Ibid., 25.

${ }^{34}$ See William Garrett Piston, Lee's Tarnished Lieutenant: James Longstreet and His Place in Southern History (Athens: University of Georgia Press, 1987).

${ }^{35}$ Gallagher and Nolan, eds., The Myth of the Lost Cause and Civil War History, 129.

${ }^{36}$ Stephens, Commanding the Storm, 78.

${ }^{37}$ Ibid., 16.

${ }^{38}$ Fritz, Voices in the Storm, 81.

${ }^{39}$ Franklin, Reconstruction after the Civil War, 3.

${ }^{40}$ Gallagher and Nolan, eds., The Myth of the Lost Cause and Civil War History, 21.

${ }^{41}$ Franklin, Reconstruction after the Civil War, 24.

${ }^{42}$ Gallagher and Nolan, eds., The Myth of the Lost Cause and Civil War History, 15-16.

${ }^{43}$ Davis, The Cause Lost, 178.

${ }^{44}$ Connelly and Bellows, God and General Longstreet, 10.

${ }^{45}$ See Edward H. Bonekemper III, A Victor, Not a Butcher: Ulysses S. Grant's Overlooked Military Genius (Washington, DC: Regnery Publishing, 2004), for an excellent rebuttal to outdated Lost Cause arguments about Grant's generalship. ${ }^{46}$ Davis, The Cause Lost, 177.

${ }^{47}$ Gaines M. Foster, Ghosts of the Confederacy: Defeat, the Lost Cause, and the Emergence of the New South, 1865-1913 (New York: Oxford University Press, 1987), 4.

${ }^{48}$ Gallagher and Nolan, eds., The Myth of the Lost Cause and Civil War History, 3.

${ }^{49}$ See David W. Blight, Race and Reunion: The Civil War in American Memory (Cambridge, MA: Belknap Press of Harvard University Press, 2001).

${ }^{50}$ Randall and Donald, The Civil War and Reconstruction, 688. 


\section{REFERENCES}

\section{$\underline{\text { Primary Works }}$}

Chesnut, Mary. Diary of Mary Chesnut. Fairfax, VA: D. Appleton and Company, 1905.

Early, Jubal Anderson. A Memoir of the Last Year of the War for Independence in the Confederate States of America: Containing an Account of the Operations of His Commands in the Years 1864 and 1865. Edited by Gary W. Gallagher. Columbia, SC: University of South Carolina Press, 2001.

Gordon, John Brown. Reminiscences of the Civil War. New York: Charles Scribner's Sons, 1903.

Hood, John Bell. Advance and Retreat: Personal Experiences in the United States and Confederate States Armies. Lincoln: University of Nebraska Press, 1996.

Jomini, Antoine Henri de. The Art of War. Mechanicsburg, PA: Stackpole Books, 1854.

Johnston, Joseph E. Narrative of Military Operations: Directed, During the Late War Between the States. New York: D. Appleton \& Co., 1874.

Longstreet, James. From Manassas to Appomattox: Memoirs of the Civil War in America. New York: De Capo Press, 1896.

McLaws, Lafayette. A Soldier's General: The Civil War Letters of Major General Lafayette McLaws. Chapel Hill: University of North Carolina Press, 2002.

U.S. Census Office, Eighth Census [1860], Agriculture of the United States in 1860. Washington, D.C., 1864.

U.S. Census Office, Eighth Census [1860], Population of the United States in 1860. Washington, D.C., 1864.

United States War Department. The War of the Rebellion: A Compilation of the Official Records of the Union and Confederate Armies. Washington: Government Printing Office, 1880-1901.

\section{$\underline{\text { Secondary Works }}$}

Adams, Michael C. C. Our Masters the Rebels: A Speculation on Union Military Failure in the East 1861-1865. Cambridge, MA: Harvard University Press, 1978. 
Allardice, Bruce S. Confederate Colonels: A Biographical Register. Columbia: University of Missouri Press, 2008.

Andrew Jr., Rod. Long Gray Lines: the Southern Military School Tradition, 1839-1915. Chapel Hill: The University of North Caroline Press, 2001.

Ballard, Michael B. Vicksburg: the Campaign that Opened the Mississippi. Chapel Hill: University of North Carolina Press, 2010.

Beringer, Richard E. The Elements of Confederate Defeat: Nationalism, War Aims, and Religion. Athens: University of Georgia Press, 1988.

Beringer, Richard E., William N. Still Jr., Archer Jones, and Herman Hattaway. Why the South Lost the Civil War. Athens, GA: University of Georgia Press, 1986.

Berlin, Ira. Many Thousands Gone: The First Two Centuries of Slavery in North America. Cambridge, MA: The Belknap Press of Harvard University Press, 1998.

Black, Jeremy. Western Warfare 1775-1882. Bloomington: Indiana University Press, 2001.

Blair, Jayne E. The Essential Civil War: A Handbook to the Battles, Armies, Navies and Commanders. Jefferson, NC: McFarland \& Company, Inc., 2006.

Blight, David W. Race and Reunion: the Civil War in American Memory. Cambridge, MA: Belknap Press of Harvard University Press, 2001.

Boatner, Mark Mayo. The Civil War Dictionary. New York: McKay, 1998.

Bodart, Gaston. Militär-historisches kriegs-lexikon (1618-1905). Wien \& Leipzig, 1908.

Boles, John B. ed. A Companion to the American South. Oxford: Blackwell Publishers Ltd, 2002.

Bonekemper III, Edward H. A Victor, Not a Butcher: Ulysses S. Grant's Overlooked Military Genius. Washington, DC: Regnery Publishing, 2004.

Carmichael, Peter S, ed. Audacity Personified: The Generalship of Robert E. Lee. Baton Rouge: Louisiana State University Press, 2004.

Carmichael, Peter S. The Last Generation: Young Virginians in Peace, War, and Reunion. Chapel Hill: University of North Carolina Press, 2005.

Carter, Dan T. When the War Was Over: The Failure of Self-Reconstruction in the South, 1865-1867. Baton Rouge: Louisiana State University Press, 1985. 
Cash, W. J. The Mind of the South. New York: Vintage Books, 1941.

Castel, Albert A. Decision in the West: the Atlanta Campaign of 1864. Topeka: University Press of Kansas, 1992.

Catton, Bruce. Gettysburg: the Final Fury. New York: Doubleday, 1974.

Catton, Bruce. The Civil War. Boston: Houghton Mifflin Company, 1960.

Clampitt, Bradley R. The Confederate Heartland: Military and Civilian Morale in the Western Confederacy. Baton Rouge: Louisiana State University Press, 2011.

Clinton, Catherine and Nina Silber eds. Divided Houses: Gender and the Civil War. New York: Oxford University Press, 1992.

Combined Books. The Civil War Book of Lists: Over 300 Lists from the Sublime to the Ridiculous. Edison, NJ: Castle Books, 1993.

Connelly, Thomas L. and Barbara L. Bellows. God and General Longstreet: The Lost Cause and the Southern Mind. Baton Rouge: Louisiana State University Press, 1982.

Cozzens, Peter. No Better Place to Die: The Battle of Stones River. Chicago: University of Illinois, 1990.

Cozzens, Peter. This Terrible Sound: The Battle of Chickamauga. Urbana, IL: University of Illinois Press, 1992.

Daniel, Larry J. Battle of Stones River: The Forgotten Conflict Between the Confederate Army of Tennessee and the Union Army of the Cumberland. Baton Rouge: Louisiana State University Press, 2012.

Daniel, Larry J. Shiloh: The Battle That Changed the Civil War. New York: Simon \& Schuster, 1997.

Davis, William C. Battle at Bull Run: A History of the First Major Campaign of the Civil War. Baton Rouge: Louisiana State University Press, 1981.

Davis, William C. The Cause Lost: Myths and Realities of the Confederacy. Lawrence: University Press of Kansas, 1996.

Dickerson, Donna L. The Reconstruction Era: Primary Documents on Events from 1865 to 1877. Westport, CT: Greenwood Press, 2003.

Dougherty, Kevin. Civil War Leadership and Mexican War Experience. Jackson: University of Mississippi Press, 2007. 
Duffy, Christopher. Military Experience in the Age of Reason 1715-1789. New York: Barnes \& Noble Books Inc., 1987.

Dundas, J. C. "The Strategy of Exterior and Interior Lines in the Light of Modern War" Royal United Services Institution, Journal 66 (1921) 101-113.

Ecelbarger, Gary. The Day Dixie Died: The Battle of Atlanta. New York: Thomas Dunne Books, 2010.

Eicher, David J. The Longest Night: A Military History of the Civil War. New York: Simon \& Schuster, 2001.

Faulkner, William. Intruder in the Dust. New York: The Modern Library, 1948.

Faulkner, William. Requiem for a Nun. New York: Random House, 1951.

Faulkner, William. The Reivers: A Reminiscence. New York: Random House, 1962.

Faulkner, William. The Sound and the Fury. New York: The Modern Library, 1929.

Faust, Drew Gilpin. Southern Stories: Slaveholders in Peace and War. Columbia: University of Missouri Press, 1992.

Fehrenbacher, Don E. The Slaveholding Republic: An Accounting of the United States Government's Relations to Slavery. New York: Oxford University Press, 2001.

Fischer, David Hackett. Albion's Seed: Four British Folkways in America. New York: Oxford University Press, 1989.

Foner, Eric. Nothing But Freedom: Emancipation and its Legacy. Baton Rouge: Louisiana State University Press, 1983.

Foner, Eric. Reconstruction: America's Unfinished Revolution, 1863-1877. New York: Harper \& Row, 1988.

Foote, Lorien. The Gentlemen and the Roughs: Manhood, Honor, and Violence in the Union Army. New York: New York University Press, 2010.

Foote, Shelby. The Beleaguered City: the Vicksburg Campaign, December 1862-July 1863. New York: Modern Library, 1995.

Foote, Shelby. The Civil War, a Narrative: Fort Sumter to Perryville. New York: Vintage Books, 1986.

Foote, Shelby. The Civil War, a Narrative: Fredericksburg to Meridian. New York: 
Vintage Books, 1986.

Foote, Shelby. The Civil War, a Narrative: Red River to Appomattox. New York:

Vintage Books, 1986.

Foster, Gaines M. Ghosts of the Confederacy: Defeat, the Lost Cause, and the Emergence of the New South 1865-1913. New York: Oxford University Press, 1987.

Fox, William F. Regimental Losses in the American Civil War, 1861-1865: A Treatise on the Extent and Nature of the Mortuary Losses in the Union Regiments, with Full and Exhaustive Statistics Compiled from the Official Records on File in the State Military Bureaus and at Washington. Albany: Brandow Printing Company, 1898.

Fox-Genovese, Elizabeth. Within the Plantation Household: Black and White Women of the Old South. Chapel Hill: University of North Carolina Press, 1988.

Franklin, John Hope. Reconstruction after the Civil War, $2^{\text {nd }}$ Edition. Chicago: University of Chicago Press, 1994.

Franklin, John Hope. The Militant South: 1800-1861. Chicago: University of Illinois Press, 1984.

Freehling, William W. The Reintegration of American History: Slavery and the Civil War. New York: Oxford University Press, 1994.

Freehling, William W. The Road to Disunion Volume I: Secessionists at Bay, 1776-1854. New York: Oxford University Press, 1990.

Freehling, William W. The Road to Disunion Volume II: Secessionists Triumphant, 18541861. New York: Oxford University Press, 2007.

Freeman, Douglas Southall. R. E. Lee: A Biography, 4 vols. New York: Charles Scribner's Sons, 1934.

Fritz, Karen E. Voices in the Storm: Confederate Rhetoric, 1861-1865. Denton: University of North Texas Press, 1999.

Gallagher, Gary W. Jubal A. Early, the Lost Cause, and Civil War History: A Persistent Legacy. Milwaukee, WI: Marquette University Press, 1995.

Gallagher, Gary W. Lee and His Army in Confederate History. Chapel Hill: University of North Carolina Press, 2001.

Gallagher, Gary W. The Confederate War: How Popular Will, Nationalism, and Military Strategy Could Not Stave Off Defeat. Cambridge, MA: Harvard University Press, 1999. 
Gallagher, Gary W. ed. The Fredericksburg Campaign: Decision on the Rappahannock. Chapel Hill: University of North Carolina Press, 1995.

Gallagher, Gary W. ed. The Wilderness Campaign. Chapel Hill: University of North Carolina Press, 2006.

Gallagher, Gary W. and Alan T. Nolan, eds. The Myth of the Lost Cause and Civil War History. Bloomington: Indiana University Press, 2010.

Gat, Azar. A History of Military Thought: from the Enlightenment to the Cold War. New York: Oxford University Press, 2001.

Gates, David. Warfare in the Nineteenth Century. New York: Palgrave, 2001.

Genovese, Eugene D. Fatal Self-Deception: Slaveholding Paternalism in the Old South. New York: Cambridge University Press, 2011.

Genovese, Eugene D. The Political Economy of Slavery: Studies in the Economy and Society of the Slave South. Middletown, CT: Wesleyan University Press, 1989.

Genovese, Eugene D. The Southern Front: History and Politics in the Cultural War. Columbia: University of Missouri Press, 1995.

Glatthaar, Joseph T. General Lee's Army: From Victory to Collapse. New York: Free Press, 2008.

Glatthaar, Joseph T. Soldiering in the Army of Northern Virginia: A Statistical Portrait of the Troops Who Served Under Robert E. Lee. Chapel Hill: University of North Carolina Press, 2011.

Goldfield, David R. Still Fighting the Civil War: The American South and Southern History. Baton Rouge: Louisiana State University Press, 2002.

Grant, Susan-Mary. North Over South: Northern Nationalism and American Identity in the Antebellum Era. Lawrence: University Press of Kansas, 2000.

Greenberg, Kenneth S. Honor and Slavery: Lies, Duels, Noses, Mash, Dressing as a Woman, Gifts, Strangers, Humanitarianism, Death, Slave Rebellions, the ProSlavery Argument, Baseball, Hunting, and Gambling in the Old South. Princeton, NJ: Princeton University Press, 1996.

Greer, Darroch. "Counting Civil War Casualties, Week-By-Week, Article for the Abraham Lincoln Presidential Library and Museum" Abraham Lincoln Presidential Library and Museum, 2005. http://www.brcweb.com/alplm/BRC_Counting_Casualties.pdf 
Griffith, Paddy. Battle Tactics of the Civil War. New Haven: Yale University Press, 2001.

Groom, Winston. Vicksburg, 1863. New York: Alfred A. Knopf, 2009.

Guelzo, Allen. Gettysburg: the Last Invasion. New York: Alfred A. Knopf, 2013.

Hacker, J. David. "A Census-Based Count of the Civil War Dead" Civil War History, 57, December 2011.

Hankinson, Alan. First Bull Run 1861: The South's First Victory. Westport, CT: Praeger, 2004.

Harsh, Joseph L. Confederate Tide Rising: Robert E. Lee and the Making of Southern Strategy, 1861-1862. Kent, OH: Kent State University Press, 1998.

Hartwig, David S. To Antietam Creek: The Maryland Campaign of September 1862. Baltimore: The Johns Hopkins University Press, 2012.

Harwell, Richard B. ed. The Confederate Reader. New York: Longmans, Green and Co., 1957.

Haughton, Andrew. Training, Tactics and Leadership in the Confederate Army of Tennessee: Seeds of Failure. London: Frank Cass Publishers, 2000.

Hess, Earl J. Banners to the Breeze: The Kentucky Campaign, Corinth, and Stones River. Lincoln: University of Nebraska Press, 2000.

Hess, Earl J. The Civil War in the West: Victory and Defeat from the Appalachians to the Mississippi. Chapel Hill: University of North Carolina Press, 2012.

Hess, Earl J. Trench Warfare under Grant and Lee: Field Fortifications in the Overland Campaign. Chapel Hill: University of North Carolina Press, 2007.

Higginbotham, R. Don. "The Martial Spirit in the Antebellum South: Some Further Speculations in a National Context," Journal of Southern History 58 (Feb. 1992), $3-26$.

Hood, Stephen M. John Bell Hood: The Rise, Fall, and Resurrection of a Confederate General. El Dorado Hills, CA: Savas Beatie L. L. C., 2013.

Hsieh, Wayne Wei-saing. West Pointers and the Civil War. Chapel Hill: University of North Carolina Press, 2009.

Hunt, Robert. The Good Men Who Won the War: Army of the Cumberland Veterans and Emancipation Memory. Tuscaloosa: University of Alabama Press, 2010. 
Jespersen, Hal. "Map of the Battle of Franklin of the American Civil War, showing the Union defensive lines at 4:30 PM." http://www.posix.com/CWmaps/

Johnson, David Alan. Decided on the Battlefield: Grant, Sherman, Lincoln and the Election of 1864. Amherst, NY: Prometheus Books, 2012.

Jones, Archer. Civil War Command and Strategy: The Process of Victory and Defeat. New York: Free Press, 1992.

Jones, Archer. Confederate Strategy from Shiloh to Vicksburg. Baton Rouge: Louisiana State University Press, 1961.

Jones, J. Williams. Life and Letters of Robert Edward Lee, Soldier, and Man. New York: The Neale Publishing Company, 1906.

Keegan, John. The American Civil War: A Military History. New York: Random House, Inc., 2009.

Keegan, John. The Face of Battle: A Study of Agincourt, Waterloo, and the Somme. New York: Penguin Group, 1978.

Knight, James R. The Battle of Franklin: When the Devil Had Full Possession of the Earth. Charleston, SC: The History Press, 2009.

Leckie, Robert. None Died in Vain: The Saga of the American Civil War. New York: Harper Perennial, 1990.

Levine, Bruce. Half Slave and Half Free: The Roots of the Civil War. New York: Hill and Wang, 2005.

Levine, Bruce. The Fall of the House of Dixie: The Civil War and the Social Revolution that Transformed the South. New York: Random House, 2013.

Linderman, Gerald F. Embattled Courage: the Experience of Combat in the American Civil War. New York: Free Press, 1987.

Livermore, Thomas, L. Numbers and Losses in the Civil War in America: 1861-1865. Bloomington: Indiana University Press, 1957.

Long, A. L., Memoirs of Robert E. Lee: His Military and Personal History. New York: J. M. Stoddart \& Company, 1887.

Long, E. B., The Civil War Day by Day: An Almanac 1861-1865. New York: Da Capo Press, 1971. 
Lynn, John A. Battle: A History of Combat and Culture from Ancient Greece to Modern America. New York: Basic Books, 2008.

Manning, Chandra. What This Cruel War was Over: Soldiers, Slavery, and the Civil War. New York: Alfred A. Knopf, 2007.

McArthur, Judith N. A Gentleman and an Officer: A Military and Social History of James B. Griffin's Civil War. New York: Oxford University Press, 1996.

McCurry, Stephanie. Confederate Reckoning: Power and Politics in the Civil War South. Cambridge, MA: Harvard University Press, 2010.

McCurry, Stephanie. Masters of Small Worlds: Yeoman Households, Gender Relations, \& the Political of the Antebellum South Carolina Low Country. New York: Oxford University Press, 1995.

McDonough, James L. Shiloh, in Hell Before Night. Knoxville: University of Tennessee Press, 1977.

McMurry, Richard M. Two Great Rebel Armies: An Essay in Confederate Military History. Chapel Hill: University of North Carolina Press, 1989.

McPherson, James M. Abraham Lincoln and the Second American Revolution. New York: Oxford University Press, 1992.

McPherson, James M. Battle Cry of Freedom: The Civil War Era. New York: Oxford University Press, 1988.

McPherson, James M. Crossroads of Freedom: Antietam. New York: Oxford University Press, 2002.

McPherson, James M. For Cause and Comrades: Why Men Fought in the Civil War. New York: Oxford University Press, 1998.

McPherson, James M. Tried By War: Abraham Lincoln as Commander-In-Chief. New York: Penguin Press, 2008.

McWhiney, Grady. Confederate Crackers and Cavaliers. Abilene, TX: McWhiney Foundation Press, 2002.

McWhiney, Grady and Perry D. Jamieson. Attack and Die: Civil War Tactics and the Southern Heritage. Tuscaloosa: The University of Alabama Press, 1982.

Millet, Allan R. and Peter Maslowski. For the Common Defense: A Military History of the United States. New York: Free Press, 1994. 
Mills, Cynthia J. \& Pamela H. Simpson. Monuments to the Lost Cause: Women, Art, and the Landscapes of Southern Memory. Knoxville: University of Tennessee Press, 2003.

Morrison Jr., James L. The Best School in the World: West Point, the Pre-Civil War Years, 1833-1866. Kent, OH: The Kent State University Press, 1986.

Nelson, Scott Reynolds. Iron Confederacies: Southern Railways, Klan Violence, and Reconstruction. Chapel Hill: University of North Carolina Press, 1999.

Nolan, Alan T. Lee Considered: General Robert E. Lee and Civil War History. Chapel Hill: University of North Carolina Press, 1991.

O’Brien, Michael. Rethinking the South: Essays in Intellectual History. Athens: University of Georgia Press, 1993.

Osterweis, Rollin G. The Myth of the Lost Cause, 1865-1900. Hamden, CT: Archon Books, 1973.

Pace, Robert F. Halls of Honor: College Men in the Old South. Baton Rouge: Louisiana State University Press, 2004.

Paskoff, Paul F. "Measures of War: A Quantitative Examination of the Civil War's Destructiveness in the Confederacy," Civil War History, 54 (March 2008), 35-62.

Piston, William Garrett. Lee's Tarnished Lieutenant: James Longstreet and His Place in Southern History. Athens: University of Georgia Press, 1987.

Phillips, Jason. Diehard Rebels: The Confederate Culture of Invincibility. Athens, GA: University of Georgia Press, 2007.

Phipps, Michael. "Mahan at Westpoint, 'Gallic Bias,' and the 'Old Army': The Subconscious Leadership at Gettysburg." National Park Service Gettysburg Seminar Papers, 1999. http://www.nps.gov/history/history/online_books/gett/gettysburg_seminars/9/essa y1.pdf

Phisterer, Frederick K. Statistical Record of the Armies of the United States. New York: Charles Scribner's Sons, 1883.

Proctor, Nicolas W. Bathed in Blood: Hunting and Mastery in the Old South. Charlottesville, VA: University Press of Virginia, 2002.

Rable, George C. But There Was No Peace: The Role of Violence in the Politics of Reconstruction. Athens: University of Georgia Press, 1984. 
Rable, George C. Fredericksburg! Fredericksburg! Chapel Hill: University of North Carolina Press, 2002.

Rafuse, Ethan S. A Single Grand Victory: The First Campaign and Battle of Manassas. Wilmington, DE: Rowan \& Littlefield Publishers, 2002.

Randall, J. G. and David Hebert Donald. The Civil War and Reconstruction. $2^{\text {nd }}$ edition. Lexington, MA: D. C. Heath and Company, 1969.

Reardon, Carol. Pickett's Charge in History and Memory. Chapel Hill: University of North Carolina Press, 1997.

Reardon, Carol. With a Sword in One Hand \& Jomini in the Other: The Problem of Military Thought in the Civil War North. Chapel Hill: University of North Carolina Press, 2012.

Riley, Jonathon. Napoleon As a General: Command From the Battlefield to Grand Strategy. New York: Hambledon Continuum, 2007.

Roark, James L. Masters Without Slaves: Southern Planters in the Civil War and Reconstruction. New York: Norton, 1977.

Rothenberg, Gunther, E. The Art of Warfare in the Age of Napoleon. Bloomington: Indiana University Press, 1978.

Remini, Robert V. Andrew Jackson and the Course of American Freedom, 1822-1832. Baltimore: The John Hopkins University Press, 1981.

Rubin, Anne Sarah. A Shattered Nation: The Rise and Fall of the Confederacy, 1861 1868. Chapel Hill: University of North Carolina Press, 2005.

Saunders, Anthony. Trench Warfare 1850-1950. Barnsley: Pen \& Sword Military, 2010.

Sears, Stephen W. Gettysburg. Boston: Houghton Mifflin, 2003.

Sears, Stephen W. Landscape Turned Red: the Battle of Antietam. New York: Houghton Mifflin Company, 2003.

Simson, Jay W. Naval Strategies of the Civil War: Confederate Innovations and Federal Opportunism. Nashville: Cumberland House, 2001.

Sutherland, Daniel E. A Savage Conflict: The Decisive Role of Guerrillas in the American Civil War. Chapel Hill: University of North Carolina Press, 2009.

Stephens, John Richard. Commanding the Storm: Civil War Battles in the Words of the Generals Who Fought Them. Guilford, CT: Lyons Press, 2012. 
Strachan, Hew. European Armies and the Conduct of War. New York: Routledge, 2004.

Swanson, James. Manhunt: The 12-Day Chase for Lincoln's Killer. New York: William Morrow Paperbacks, 2007.

Sword, Wiley. The Confederacy's Last Hurrah: Spring Hill, Franklin, and Nashville. Lawrence: University Press of Kansas, 1993.

Sword, Wiley. Southern Invincibility: A History of the Confederate Heart. New York: St. Martin's Griffin, 1999.

Symonds, Craig L. Joseph E. Johnston: A Civil War Biography. New York:

W. W. Norton \& Company, Inc., 1992.

Tanner, Robert G. Retreat to Victory: Confederate Strategy Reconsidered. Wilmington, DE: Scholarly Resources Inc. 2001.

Taylor, William Robert. Cavalier and Yankee: The Old South and American National Character. Garden City, NY: Anchor Books, 1961.

The Economist. "The Civil War, Finally Passing: Assessing America’s Bloodiest War, 150 years later." The Economist, March 31, 2011.

http://www.economist.com/node/18486035?story_id=18486035

Thomas, Emory. The Confederate Nation 1861-1865. New York: Harper Perennial, 1979.

Tucker, Glenn. Chickamauga: Bloody Battle in the West. Dayton, OH: Morningside Bookshop, 1976.

Tucker, Spencer C. Blue and Gray Navies: The Civil War Afloat. Annapolis: Naval Institute Press, 2006.

Valelly, Richard M. The Two Reconstructions: The Struggle for Black Enfranchisement. Chicago: University of Chicago Press, 2004.

Warner, Ezra J. Generals in Gray: Lives of Confederate Commanders. Baton Rouge: Louisiana State University Press, 1959.

Weigley, Russell F. A Great Civil War: A Military and Political History, 1861-1865. Bloomington: Indiana University Press, 2000.

Weigley, Russell F. The Age of Battles: The Quest for Decisive Warfare from Breitenfeld to Waterloo. Bloomington: Indiana University Press, 1991. 
Weigley, Russell F. The American Way of War: A History of United States Military Strategy and Policy. New York: Macmillan Publishing Company, 1973.

Weigley, Russell F. Towards an American Army: Military Thought from Washington to Marshall. New York: Columbia University Press, 1962.

White, Matthew. "Statistics of Wars, Oppressions and Atrocities of the Nineteenth Century (the 1800s)." Last modified March 2011. Accessed October 16, 2013. http://necrometrics.com/wars19c.htm

Whites, LeeAnn. The Civil War as a Crisis in Gender: Augusta, Georgia 1860-1890. Athens: The University of Georgia Press, 1995.

Whites, LeeAnn and Alecia P. Long eds. Occupied Women: Gender and Military Occupation and the American Civil War. Baton Rouge: Louisiana State University Press, 2009.

Wilson, Charles Reagan. Baptized in Blood: the Religion of the Lost Cause, 1865-1920. Athens: University of Georgia Press, 2009.

Woodworth, Steven E., ed. Civil War Generals in Defeat. Lawrence: University Press of Kansas, 1999.

Woodworth, Steven E. Six Armies in Tennessee: The Chickamauga and Chattanooga Campaigns. Lincoln: University of Nebraska Press, 1998.

Woodworth, Steven E. The Shiloh Campaign. Carbondale: Southern Illinois University Press, 2009.

Woodworth, Steven E. While God is Marching On: The Religious World of Civil War Soldiers. Lawrence: University Press of Kansas, 2001.

Wyatt-Brown, Bertram. The Shaping of Southern Culture: Honor, Grace, and War, 1760s-1880s. Chapel Hill: University of North Carolina Press, 2001.

Wyatt-Brown, Bertram. Southern Honor: Ethics and Behavior in the Old South. New York: Oxford University Press, 2007.

Young III, Alfred C. Lee's Army During the Overland Campaign: A Numerical Study. Baton Rouge: Louisiana University Press, 2013. 


\section{CURRICULUM VITA}

Name: $\quad$ Matthew D. Goldberg

Address: $\quad 3509$ Sorrento Ave.

Louisville, KY 40208

\section{Education}

2011-Present: University of Louisville, M.A. History (3.92 GPA)

Master's Thesis: Southern Honor, Confederate Warfare: Antebellum Southern

Cultural Values in the Confederate Military, 1861-1865

2011: University of Louisville, Honors B.A. History (Magna cum Laude, 3.82 GPA)

Selected Publications

- Review: Bradley R. Clampitt, The Confederate Heartland: Military and Civilian Morale in the Western Confederacy, Ohio Valley History 12 (Spring 2012), 9596.

\section{Selected Awards}

- 2013: Most Outstanding Graduate Student: University of Louisville, History Department

- 2013: Dean's Citation (nominated by History Department, won)

- 2011: Woodcock Society, University of Louisville (Membership offered to top $10 \%$ of graduating A\&S students)

- 2007-2011: Trustees Scholarship, University of Louisville

- 2007-2011: Dean's List, University of Louisville 